Prepared in cooperation with the U.S. Environmental Protection Agency

\title{
Hydrologic Site Assessment for Passive Treatment of Groundwater Nitrogen With Permeable Reactive Barriers, Cape Cod, Massachusetts
}

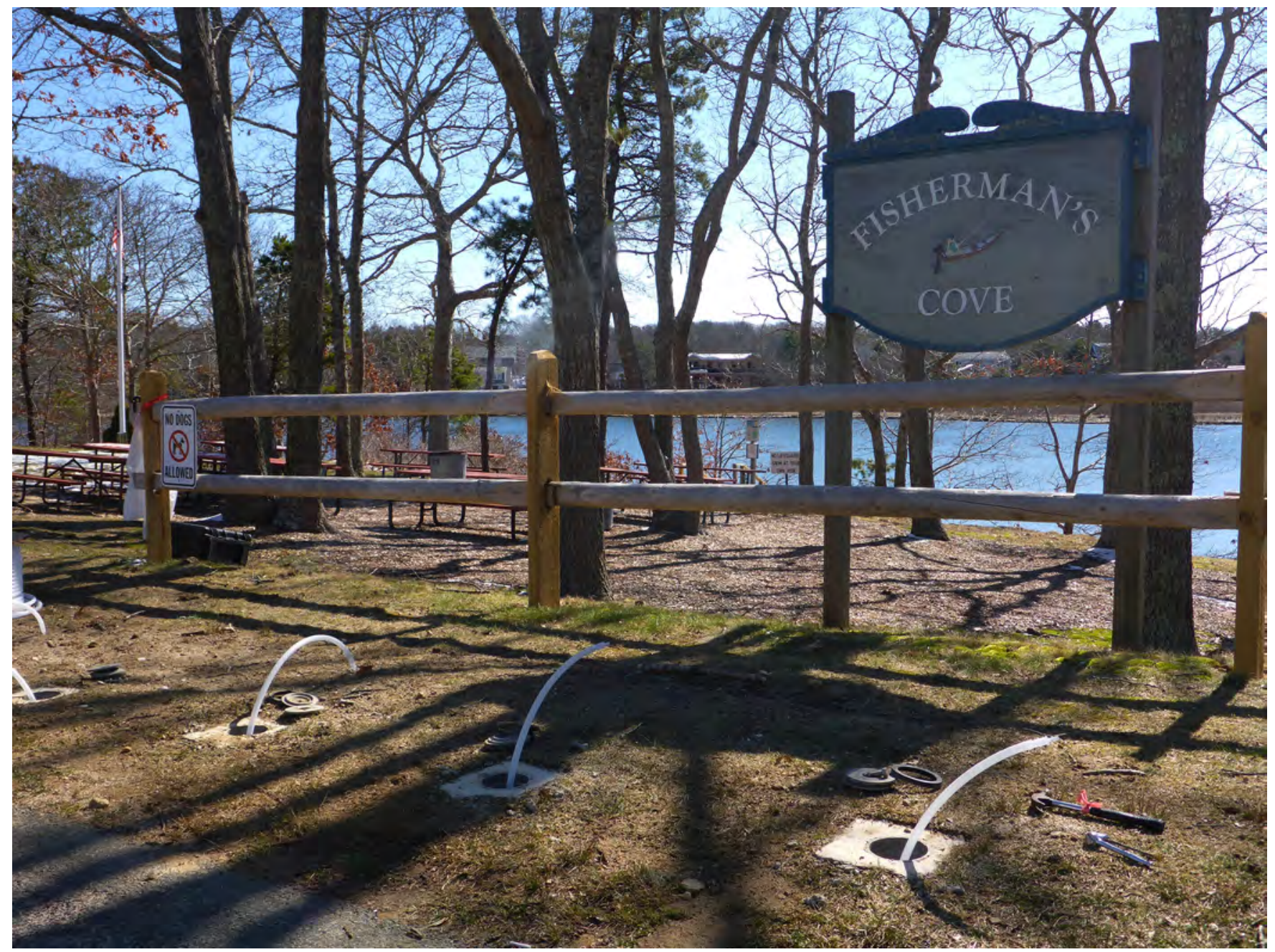

Scientific Investigations Report 2019-5047 
Cover. Groundwater monitoring wells along Sailfish Drive in Falmouth, Massachusetts. Photograph by Marcel Belaval, U.S. Environmental Protection Agency. 


\section{Hydrologic Site Assessment for Passive Treatment of Groundwater Nitrogen With Permeable Reactive Barriers, Cape Cod, Massachusetts}

By Jeffrey R. Barbaro, Marcel Belaval, Danna B. Truslow, Denis R. LeBlanc,

Thomas C. Cambareri, and Scott C. Michaud

Prepared in cooperation with the U.S. Environmental Protection Agency

Scientific Investigations Report 2019-5047 


\title{
U.S. Department of the Interior DAVID BERNHARDT, Secretary
}

\author{
U.S. Geological Survey \\ James F. Reilly II, Director
}

U.S. Geological Survey, Reston, Virginia: 2019

For more information on the USGS - the Federal source for science about the Earth, its natural and living resources, natural hazards, and the environment-visit https://www.usgs.gov or call 1-888-ASK-USGS.

For an overview of USGS information products, including maps, imagery, and publications, visit https://store.usgs.gov.

Any use of trade, firm, or product names is for descriptive purposes only and does not imply endorsement by the U.S. Government.

Although this information product, for the most part, is in the public domain, it also may contain copyrighted materials as noted in the text. Permission to reproduce copyrighted items must be secured from the copyright owner.

Suggested citation:

Barbaro, J.R., Belaval, M., Truslow, D.B., LeBlanc, D.R., Cambareri, T.C., and Michaud, S.C., 2019, Hydrologic site assessment for passive treatment of groundwater nitrogen with permeable reactive barriers, Cape Cod, Massachusetts: U.S. Geological Survey Scientific Investigations Report 2019-5047, 39 p., https://doi.org/10.3133/sir20195047.

ISSN 2328-0328 (online) 


\section{Acknowledgments}

The authors thank the officials and citizens of the Towns of Barnstable, Dennis, Falmouth, Mashpee, and Orleans who proposed sites for this study and provided the geographic and environmental data that were used to select and investigate the study sites. The assistance of personnel from New England Geotech, Inc., Alpha Analytical, and Comprehensive Environmental, Inc., for drilling and analytical services during the field investigations is gratefully acknowledged. Financial support for the study was provided by the U.S. Environmental Protection Agency, Region 1, Southeast New England Program for Coastal Watershed Restoration (SNEP). The authors also thank Peter Weiskel, Riley Gannon, Leslie DeSimone, Matt Ely, and Isaac Bukowski of the U.S. Geological Survey for technical assistance. 



\section{Contents}

Acknowledgments ……...................................................................................................................

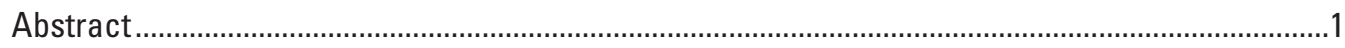

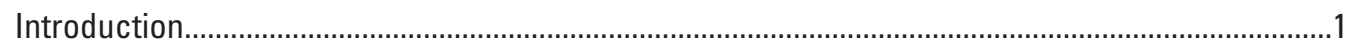

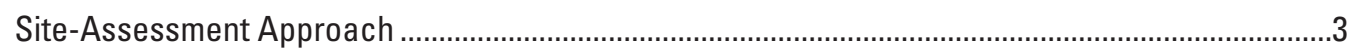

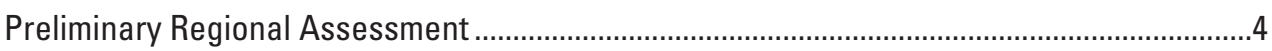

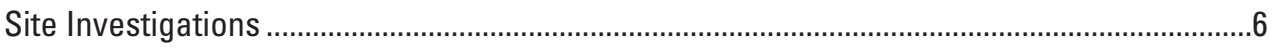

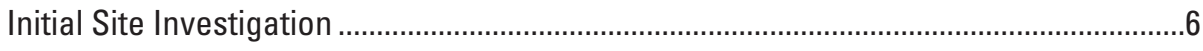

Full Site Investigation ...................................................................................................

Overview of Cape Cod Site Investigations ......................................................................

Installation of Shallow Monitoring Wells............................................................

Collection of Aquifer Materials ................................................................................

Installation of Well Clusters ......................................................................................

Measurement of Hydraulic Head ................................................................................

Collection of Water-Quality Samples.............................................................................

Estimation of Hydraulic Conductivity....................................................................

Site-Assessment Results.........................................................................................................

Prince Avenue Near Prince Cove in Barnstable ...................................................................14

Sailfish Drive Near Bournes Pond in Falmouth ................................................................17

Herring Brook Way Near Kescayo Gansett Pond (Lonnies Pond) in Orleans .........................20

Timber Landing Road Near the Mashpee River in Mashpee ...............................................23

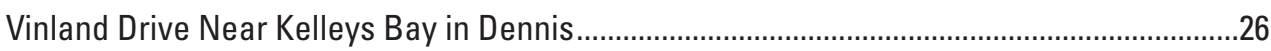

Preliminary Regional Assessment and Initial Site Investigation ..................................26

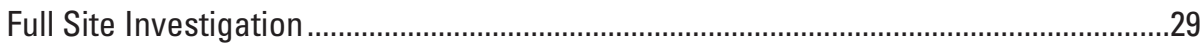

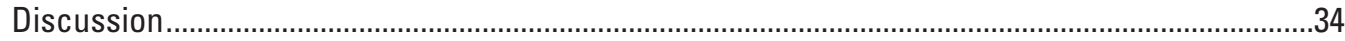

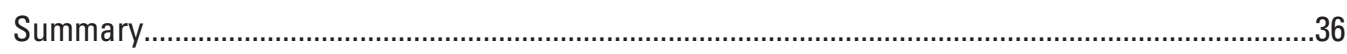

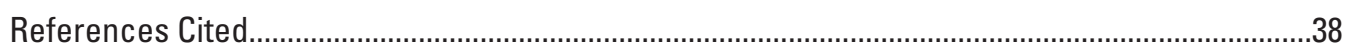

\section{Figures}

1. Map showing locations of five sites investigated to determine hydrologic suitability for installation of permeable reactive barriers for passive treatment of groundwater nitrogen on Cape Cod, Massachusetts.

2. Screen shot from the Cape Cod Commission WatershedMVP application, showing the simulated subwatershed to Kelleys Bay and the contributing area to a potential permeable reactive barrier at the Vinland Drive near Kelleys Bay site in Dennis, Massachusetts.

3. Map showing topographic and hydrologic features, monitoring wells installed for the initial site investigation, and altitude of the water table at the Prince Avenue near Prince Cove site in Barnstable, Massachusetts

4. Graphs showing $A$, the vertical distributions of specific conductance, dissolved oxygen, dissolved iron, and nitrate as nitrogen in groundwater, $B$, the vertical distribution of hydraulic head, and $C$, the generalized stratigraphy at the Prince Avenue near Prince Cove site in Barnstable, Massachusetts 
5. Map showing topographic and hydrologic features, monitoring wells installed for the initial site investigation, and altitude of the water table at the Sailfish Drive near Bournes Pond site in Falmouth, Massachusetts.

6. Graphs showing $A$, the vertical distributions of specific conductance, dissolved oxygen, dissolved iron, and nitrate as nitrogen in groundwater, $B$, the vertical distribution of hydraulic head, and $C$, the generalized stratigraphy at the Sailfish Drive near Bournes Pond site in Falmouth, Massachusetts

7. Map showing topographic and hydrologic features, monitoring wells installed for the initial site investigation, and altitude of the water table at the Herring Brook Way near Kescayo Gansett Pond (Lonnies Pond) site in Orleans, Massachusetts ........21

8. Graphs showing $A$, the vertical distributions of specific conductance, dissolved oxygen, dissolved iron, and nitrate as nitrogen in groundwater, $B$, the vertical distribution of hydraulic head, and $C$, the generalized stratigraphy at the Herring Brook Way near Kescayo Gansett Pond (Lonnies Pond) site in Orleans, Massachusetts

9. Map showing topographic and hydrologic features, monitoring wells installed for the initial site investigation, and the altitude of the water table at the Timber Landing Road near the Mashpee River site in Mashpee, Massachusetts

10. Graphs showing $A$, the vertical distributions of specific conductance, dissolved oxygen, dissolved iron, and nitrate as nitrogen in groundwater, $B$, the vertical distribution of hydraulic head, and $C$, the generalized stratigraphy at the Timber Landing Road near the Mashpee River site in Mashpee, Massachusetts

11. Map showing topographic and hydrologic features, monitoring wells installed for the initial site investigation, and the altitude of the water table at the Vinland Drive near Kelleys Bay site in Dennis, Massachusetts.

12. Graphs showing $A$, the vertical distributions of specific conductance, dissolved oxygen, dissolved iron, and nitrate as nitrogen in groundwater, $B$, the vertical distribution of hydraulic head, and $C$, the generalized stratigraphy at the Vinland Drive near Kelleys Bay site in Dennis, Massachusetts.

13. Maps showing topographic and hydrologic features, monitoring wells, drive points, surface-water sampling sites installed for the initial and full site investigations, and the altitude of $A$, the water table in the upper sand unit, and $B$, the potentiometric surface in the lower sand unit at the Vinland Drive near Kelleys Bay site in Dennis, Massachusetts

14. Graphs showing the vertical distributions of specific conductance, dissolved oxygen, dissolved iron, and nitrate as nitrogen in groundwater at well clusters $A, \mathrm{VLZ}, B, \mathrm{VLZ}-4, C, \mathrm{VLZ}-6$, and $D, \mathrm{VLZ}-7$ at the Vinland Drive near Kelleys Bay site in Dennis, Massachusetts. 


\section{Tables}

1. Favorable location criteria used in the preliminary regional assessment to identify potential permeable reactive barrier sites for passive treatment of groundwater nitrogen on Cape Cod, Massachusetts...

2. Hydrologic, nitrogen-loading, and site-access data compiled for the preliminary regional assessment of potential permeable reactive barrier sites for passive treatment of groundwater nitrogen on Cape Cod, Massachusetts

3. Original specifications for initial and full site investigations to identify potential permeable reactive barrier sites for passive treatment of groundwater nitrogen on Cape Cod, Massachusetts

4. Water-quality constituents measured in groundwater during initial and full site investigations to identify potential permeable reactive barrier sites for passive treatment of groundwater nitrogen on Cape Cod, Massachusetts

5. Initial site investigation well-construction specifications and selected water-quality and hydraulic-head results at sites investigated to determine hydrologic suitability for installation of permeable reactive barriers for passive treatment of groundwater nitrogen on Cape Cod, Massachusetts.

6. Full site investigation well-construction specifications and selected water-quality and hydraulic-head results at the Vinland Drive near Kelleys Bay site in Dennis, Massachusetts

7. Estimated and calculated nitrogen loads at sites investigated to determine hydrologic suitability for installation of permeable reactive barriers for passive treatment of groundwater nitrogen on Cape Cod, Massachusetts.

8. Hydraulic conductivity of the glacial stratified drift determined from grain-size analysis at the Vinland Drive near Kelleys Bay site in Dennis, Massachusetts

9. Hydraulic conductivity of the glacial stratified drift determined from slug tests at the Vinland Drive near Kelleys Bay site in Dennis, Massachusetts 


\section{Conversion Factors}

U.S. customary units to International System of Units

\begin{tabular}{lll}
\hline \multicolumn{1}{c}{ Multiply } & By & \multicolumn{1}{c}{ To obtain } \\
\hline inch (in.) & 2.54 & centimeter $(\mathrm{cm})$ \\
foot (ft) & 0.3048 & meter $(\mathrm{m})$ \\
mile (mi) & 1.609 & kilometer $(\mathrm{km})$ \\
acre & 0.004047 & square kilometer $\left(\mathrm{km}^{2}\right)$ \\
foot per day (ft/d) & 0.3048 & meter per day $(\mathrm{m} / \mathrm{d})$ \\
\hline
\end{tabular}

\section{Datum}

Vertical coordinate information is referenced to the North American Vertical Datum of 1988 (NAVD 88) unless otherwise indicated. Sea level is used as the reference for approximate landsurface altitudes.

Horizontal coordinate information is referenced to the North American Datum of 1983 (NAD 83). Altitude, as used in this report, refers to distance above the vertical datum.

\section{Supplemental Information}

Specific conductance is given in microsiemens per centimeter at 25 degrees Celsius $(\mu \mathrm{S} / \mathrm{cm}$ at $\left.25^{\circ} \mathrm{C}\right)$.

Concentrations of chemical constituents in water are given in milligrams per liter (mg/L).

Loads of chemical constituents in water are given in kilograms per day $(\mathrm{kg} / \mathrm{d})$ and kilograms per year $(\mathrm{kg} / \mathrm{yr})$.

\section{Abbreviations}

$\begin{array}{ll}\text { EPA } & \text { U.S. Environmental Protection Agency } \\ \text { ISI } & \text { initial site investigation } \\ \text { FSI } & \text { full site investigation } \\ N & \text { nitrogen } \\ \text { PRB } & \text { permeable reactive barrier } \\ \text { USGS } & \text { U.S. Geological Survey }\end{array}$




\title{
Hydrologic Site Assessment for Passive Treatment of Groundwater Nitrogen With Permeable Reactive Barriers, Cape Cod, Massachusetts
}

\author{
By Jeffrey R. Barbaro, ${ }^{1}$ Marcel Belaval, ${ }^{2}$ Danna B. Truslow, ${ }^{3}$ Denis R. LeBlanc, ${ }^{1}$ Thomas C. Cambareri, ${ }^{4}$ and \\ Scott C. Michaud ${ }^{4}$
}

\section{Abstract}

Wastewater disposal associated with rapid population growth and development on Cape Cod, Massachusetts, during the past several decades has resulted in widespread contamination of groundwater with nitrogen. As a result, water quality in many of the streams, lakes, and coastal embayments on Cape Cod is impaired by excess nitrogen. To reduce nitrogen loads to these impaired water bodies, watershed-based planning is currently [2019] underway following a regional strategy, the section 208 areawide water-quality management plan update for Cape Cod. In the updated plan, traditional (sewering) and alternative wastewater management options are under consideration for restoring water quality in impaired surfacewater bodies. Permeable reactive barriers, which are reactive zones emplaced below the water table for passive treatment of groundwater contaminants, are one of the alternatives being considered by Cape Cod towns as a potentially cost-effective technology for the removal of nitrogen from groundwater. However, the effectiveness of permeable reactive barriers depends on local conditions, and site-specific hydrologic and water-quality data are needed to inform the decision to install a permeable reactive barrier in a given location. These data are not available in most locations on Cape Cod; consequently, site assessments are needed before selecting this treatment option.

To address this need, the U.S. Environmental Protection Agency, U.S. Geological Survey, and Cape Cod Commission formed a technical team in 2015 to develop and evaluate a hydrologic site-assessment approach for permeable reactive barrier installation. The approach developed by the technical team includes a preliminary regional assessment followed by a phased onsite investigation. The approach was intended to provide the hydrologic data needed to make informed decisions

\footnotetext{
${ }^{1}$ U.S. Geological Survey.

${ }^{2}$ U.S. Environmental Protection Agency.

${ }^{3}$ Truslow Resource Consulting, LLC.

${ }^{4}$ Cape Cod Commission.
}

on site suitability and to support installation and monitoring should the site be deemed appropriate for a permeable reactive barrier. The factors that were evaluated to characterize local hydrologic conditions and inform site selection included groundwater flow directions and rates, depth to the water table, hydraulic conductivity and degree of heterogeneity of the aquifer, spatial distribution and concentration of nitrate and oxidation-reduction-sensitive constituents, thickness and depth of the treatment zone, distance to downgradient water bodies, and access for drilling and permeable reactive barrier installation. The approach was demonstrated on Cape Cod by conducting a preliminary assessment of 27 sites, from which 5 sites were selected for onsite investigations. Results indicated that the site-assessment approach was successful for screening sites and characterizing the geologic, hydrologic, and waterquality conditions at the sites selected for onsite investigations. Overall, the phased assessment evaluated in this study provided an efficient means of obtaining the hydrologic information needed to determine if a site was suitable for permeable reactive barrier installation on Cape Cod for the passive treatment of nitrogen in groundwater.

\section{Introduction}

Many areas on Cape Cod, Massachusetts, have experienced rapid population growth and development during the past several decades. As a result, the quality of surface waters and groundwater has been affected by excess nutrients, predominantly nitrogen, originating from onshore wastewater sources. Excess nitrogen results in increased biological productivity, which reduces water clarity, increases the frequency of harmful algal blooms, and adversely affects marine habitat by causing fish kills and diminishing shellfish populations. The coastal waters of Cape Cod are used for tourism, recreation, and commercial fisheries, and degraded water quality from excess nitrogen has negative economic effects on the region. Consequently, nutrient reductions are needed to restore water quality and maintain the healthy aquatic ecosystems relied upon by local communities. Wastewater disposal is the 
largest source of nitrogen in developed areas of Cape Cod (Cape Cod Commission, 2015). Most communities rely on domestic septic systems for wastewater disposal, resulting in widespread contamination of groundwater with nitrogen as nitrate, the most common oxidized form of nitrogen.

The impaired streams, lakes, and coastal embayments on Cape Cod are subject to Federal and State regulatory requirements to reduce nitrogen loads (Cape Cod Commission, 2015). To achieve required load reductions, watershed-based planning is currently [2019] underway following a regional strategy, the section 208 areawide water-quality management plan update, which is an update to the 1978 section 208 plan for Cape Cod (Cape Cod Commission, 2015). Developed by the Commonwealth of Massachusetts and the Cape Cod Commission, the section 208 plan update provides a flexible framework for developing strategies to improve habitat in impaired surfacewater bodies on Cape Cod, including improvements to water quality in the groundwater-contributing areas to these surfacewater bodies; a contributing area is the area at the water table that provides the groundwater recharge that ultimately discharges to a receiving water body such as a stream or coastal embayment (groundwater-contributing areas also are referred to as groundwater watersheds or subwatersheds by Cape Cod stakeholders). The section 208 plan update considers both traditional (sewering) and alternative wastewater-treatment options for achieving required nitrogen load reductions to surface-water bodies. Alternative options are under consideration because of the potential high cost and impracticality of implementing traditional municipal wastewater collection and treatment systems across Cape Cod. Alternative options for restoring water quality in impaired surface-water bodies include septic systems and toilets with advanced treatment technologies, constructed wetlands, aquaculture, widening of inlets to coastal embayments, and permeable reactive barriers (PRBs). This report focuses on the hydrologic aspects of PRB installation for passive treatment of nitrogen in groundwater on Cape Cod.

PRBs are a commonly used passive technology for treatment of point-source groundwater contamination (Interstate Technology and Regulatory Council, 2011). In the most common application of the technology, a PRB is a subsurface treatment zone emplaced in the flow path of a plume of contaminated groundwater; groundwater flows passively through the zone under natural conditions. PRBs typically are designed as linear reactive zones oriented perpendicular to groundwater flow, or, less commonly, as "funnel and gate" configurations where impermeable barriers, such as sheet piling, are used to funnel groundwater to a central subsurface treatment zone. An important PRB design consideration is the hydraulic conductivity of the treatment zone, which should be equal to or greater than that of the surrounding aquifer to minimize short circuiting of flow around the zone. Since the technology was developed in the 1990s, most PRBs have been installed to treat discrete groundwater plumes. Installations in settings with widespread, nonpoint source contamination, such as on Cape Cod, are less common.
Groundwater on Cape Cod is typically aerobic and contains nitrate as the dominant form of nitrogen derived from wastewater. Under these conditions, nitrate is nonreactive and mobile, capable of migrating substantial distances in groundwater to discharge areas. Reactive barriers for nitrate treatment typically involve adding an organic carbon source to aquifer sediment (Interstate Technology and Regulatory Council, 2011) to create the reducing conditions needed for denitrification, the microbially mediated process whereby nitrate is reduced to nitrous oxide or nitrogen gas. Common reactive materials include sawdust (Robertson and Cherry, 1995; Schipper and Vojvodic-Vukovic, 1998), wood chips (Jaynes and others, 2008; Robertson, 2010), and emulsified oils (Borden, 2007; Lee and others, 2013). Barriers can be emplaced by creating a trench that is backfilled with amended aquifer sediment or injecting emulsified organic material into a series of injection wells (Interstate Technology and Regulatory Council, 2011). However, there are few published data on the longevity (that is, continued nitrate removal capacity) of the various denitrification barrier designs (Long and others, 2011).

PRBs are being considered by Cape Cod towns as a potentially cost-effective, alternative technology for the removal of nitrogen from groundwater. The major potential advantages of passive treatment technologies such as PRBs, compared with sewer systems with centralized treatment facilities, are relatively low installation and maintenance costs and in-place subsurface treatment. However, the effectiveness of PRBs depends on local conditions; site-specific hydrologic and water-quality data are needed to inform the decision to install a PRB in a given location. Examples of the data needed for site selection include groundwater flow directions and rates, depth to the water table, hydraulic conductivity and degree of heterogeneity of the aquifer, spatial distribution and concentration of nitrate, thickness and depth of the treatment zone, distance to downgradient water bodies (with increasing distance there is a greater likelihood that untreated nitrogen sources will be present downgradient from the PRB), and access for drilling and PRB installation.

In 2015, the U.S. Environmental Protection Agency (EPA), U.S. Geological Survey (USGS), and Cape Cod Commission (CCC) formed a technical team to develop and evaluate a hydrologic site-assessment approach for PRB installation in coastal settings on Cape Cod, which is within the geographic area of the EPA's Southeast New England Program for Coastal Watershed Restoration (SNEP; https://www.epa.gov/snecwrp). The approach was intended to provide the hydrologic data needed to make informed decisions on site suitability and to support installation and monitoring should a site be deemed appropriate for a PRB. This report describes the phased hydrologic site-assessment approach developed by the technical team. The approach includes a preliminary regional assessment followed by a phased onsite investigation. The report also summarizes the results of onsite investigations conducted at five sites on Cape Cod (Prince Avenue near Prince Cove in Barnstable, Sailfish Drive near Bournes Pond in Falmouth, Herring Brook Way 


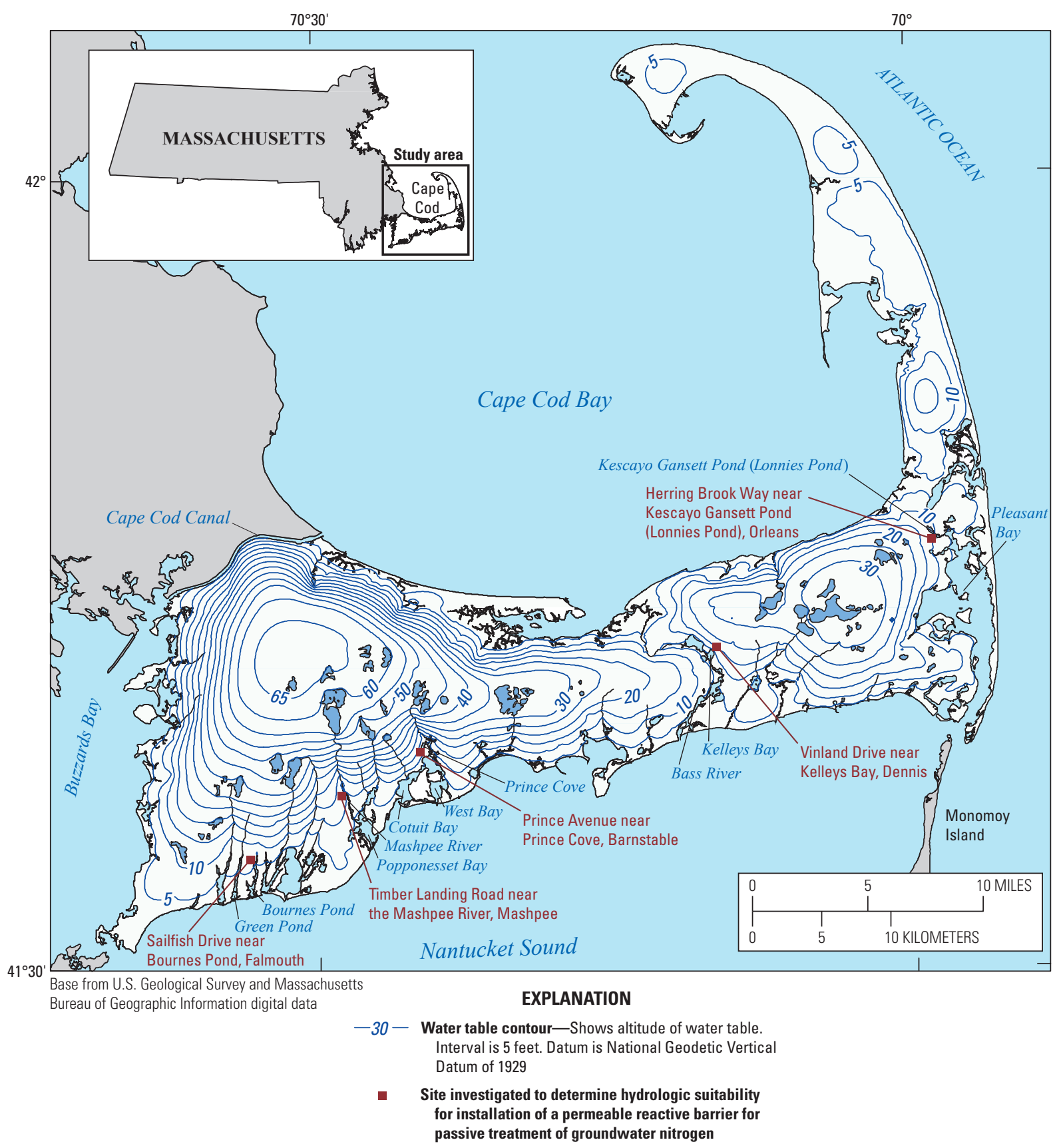

Figure 1. Locations of five sites investigated to determine hydrologic suitability for installation of permeable reactive barriers for passive treatment of groundwater nitrogen on Cape Cod, Massachusetts.

near Kescayo Gansett Pond (also known as Lonnies Pond) in Orleans, Timber Landing Road near the Mashpee River in Mashpee, and Vinland Drive near Kelleys Bay in Dennis; fig. 1) and evaluates the effectiveness of the phased approach for PRB site selection on Cape Cod.

\section{Site-Assessment Approach}

The site-assessment approach developed by the technical team includes a preliminary regional assessment followed by a phased onsite investigation conducted if favorable results were obtained from the preliminary assessment. The approach involves a preliminary regional assessment conducted by using regional-scale (Cape Cod-wide) software applications and geographic information system (GIS) tools available to identify a candidate site for the installation of a PRB for groundwater treatment. An onsite investigation would then be conducted to determine the local hydrologic and waterquality conditions at the candidate site. The final decision on site suitability would be based on observed conditions at the site. This site-assessment framework is expected to have 
general applicability for assessing potential PRB sites in other geographic areas.

The site-assessment approach was demonstrated on Cape Cod in 2016-17. The onsite investigations (well installation, water-quality sample collection and analysis, and hydraulic testing) were conducted by WaterVision, LLC, and are described in detail in Truslow and others $(2016,2017)$ and Truslow and Shanahan (2017). Detailed summaries of the onsite investigations are presented and discussed in this report to highlight the lessons learned from Cape Cod sites in the context of the site-assessment approach.

\section{Preliminary Regional Assessment}

Twenty-seven sites nominated by Cape Cod towns were included in the preliminary regional assessment. The preliminary regional assessment provided a first approximation of conditions at the nominated sites. Criteria were established to identify favorable locations for PRB installation at the watershed and local scales (table 1). The quantifiable hydrologic, nitrogen-loading, and site-access data compiled for each nominated site are described in table 2.

Information from several websites and software applications was used to obtain these data and evaluate the nominated sites (table 2). The PRB Viewer (Cape Cod Commission, 2017) is a website developed for communities on Cape Cod to assess potential PRB sites. Available data layers in the PRB Viewer includes regional water-table contours and depth to groundwater from a regional USGS groundwater model (Walter and Whealan, 2005), nitrogen load reductions needed in each subwatershed to meet water-quality standards in the receiving water body (Massachusetts Estuaries

Table 1. Favorable location criteria used in the preliminary regional assessment to identify potential permeable reactive barrier sites for passive treatment of groundwater nitrogen on Cape Cod, Massachusetts.

\begin{tabular}{ll}
\hline \multicolumn{1}{c}{ Spatial scale } & \multicolumn{1}{c}{ Favorable location criteria } \\
\hline Watershed & $\begin{array}{l}\text { Areas with high nitrogen loads to the receiving water body } \\
\text { Areas with relatively dense upgradient sources of nitrogen (to minimize uncertainty about origin of nitrogen load to } \\
\text { be treated) } \\
\text { Areas near receiving water bodies (to minimize the untreated area downgradient from the permeable reactive barrier) } \\
\text { Areas where permeable reactive barrier treatment has the potential to remove a substantial amount of the total load of } \\
\text { nitrogen reaching the receiving water body }\end{array}$ \\
Local, hydrogeology & $\begin{array}{l}\text { Areas with shallow groundwater (to facilitate placement of permeable reactive barrier material and minimize cost) } \\
\text { Areas with moderate to high groundwater flow rates associated with permeable aquifer material } \\
\text { Areas with homogeneous aquifer sediments } \\
\text { Areas where permeable reactive barrier alignment can be perpendicular to groundwater flow directions } \\
\text { Areas with previous hydrogeologic investigations }\end{array}$ \\
& $\begin{array}{l}\text { Areas on town or publicly owned land } \\
\text { Open areas away from structures } \\
\text { Areas with roads or other rights-of-way that are perpendicular to groundwater flow directions } \\
\text { Areas without significant environmental, cultural, or historical restrictions }\end{array}$ \\
\hline
\end{tabular}

Table 2. Hydrologic, nitrogen-loading, and site-access data compiled for the preliminary regional assessment of potential permeable reactive barrier sites for passive treatment of groundwater nitrogen on Cape Cod, Massachusetts.

[The PRB Viewer is at http://gis-services.capecodcommission.org/apps/JS_Developing/prb/viewer.html; the WatershedMVP is at http://www.watershedmvp.org/; the geographic information system (GIS) layers are from MassGIS (2018); the USGS regional groundwater model is from Walter and Whealan (2005). USGS, U.S. Geological Survey; MEP, Massachusetts Estuaries Project; CCC, Cape Cod Commission]

\begin{tabular}{lll}
\hline \multicolumn{1}{c}{ Hydrologic, nitrogen-loading, and site-access data } & \multicolumn{1}{c}{ Primary information source } \\
\hline Depth to groundwater & USGS regional groundwater model & PRB Viewer \\
Permeable reactive barrier orientation relative to groundwater flow direction & USGS regional groundwater model & PRB Viewer \\
Nitrogen load reduction needed in receiving water & MEP nitrogen load assessment & PRB Viewer \\
Nitrogen load to subwatershed upgradient from site & CCC nitrogen load assessment & WatershedMVP \\
Distance to receiving water body & Topographic data & GIS layers \\
Accessible location for permeable reactive barrier & Road and land-use data & GIS layers \\
\hline
\end{tabular}


Project, 2018), and ecological indicators (Massachusetts Estuaries Project, 2018). The PRB Viewer also contains a layer called "conceptual PRBs," which shows the areas where site conditions appear favorable for PRB installation based on depth to groundwater, distance to receiving water bodies, PRB orientation relative to groundwater flow direction, and the nitrogen reductions needed in the receiving water bodies. These conceptual PRB locations, which were not used in this study, also are available as a preliminary regional assessment of site suitability on Cape Cod.

The WatershedMVP web application (Cape Cod Commission, 2018) was used in the preliminary regional assessment to estimate the nitrogen load that potentially could be treated by a PRB in a selected location. The WatershedMVP application provides screening-level information for planning nitrogen-remediation scenarios on Cape Cod. The estimated nitrogen sources in version 3.1 of the WatershedMVP application include residential and commercial wastewater disposal, fertilizer application, stormwater runoff, and atmospheric deposition. Wastewater from domestic septic systems typically is the largest source of groundwater nitrogen in Cape Cod subwatersheds (Cape Cod Commission, 2018). As part of the preliminary regional assessment in this study, the
WatershedMVP application was used to estimate the wastewater nitrogen loads that enter the areas contributing groundwater to potential PRBs.

As an example, the Kelleys Bay subwatershed and groundwater-contributing area to a potential PRB along Vinland Drive are shown in figure 2. Simulated water-table contours from a regional USGS groundwater model (Walter and Whealan, 2005) were used to delineate the contributing areas to the potential PRBs. The application then computes the nitrogen load to the groundwater flow system from the sources within the contributing area polygon (fig. 2). The loads to the groundwater flow system may differ from the long-term average loads to PRBs and receiving water bodies because of variable nitrogen inputs over time, the time of travel required for nitrogen inputs to reach a PRB, and nitrogen reducing reactions in the subsurface; these temporal effects and transport processes are not accounted for in the WatershedMVP application. Consequently, the nitrogen loads from the WatershedMVP application reflect recent conditions in the subwatershed (that is, loads from recent nitrogen sources). Results of the preliminary regional assessment for the sites selected for onsite investigations are described in the "Site-Assessment Results" section of the report.

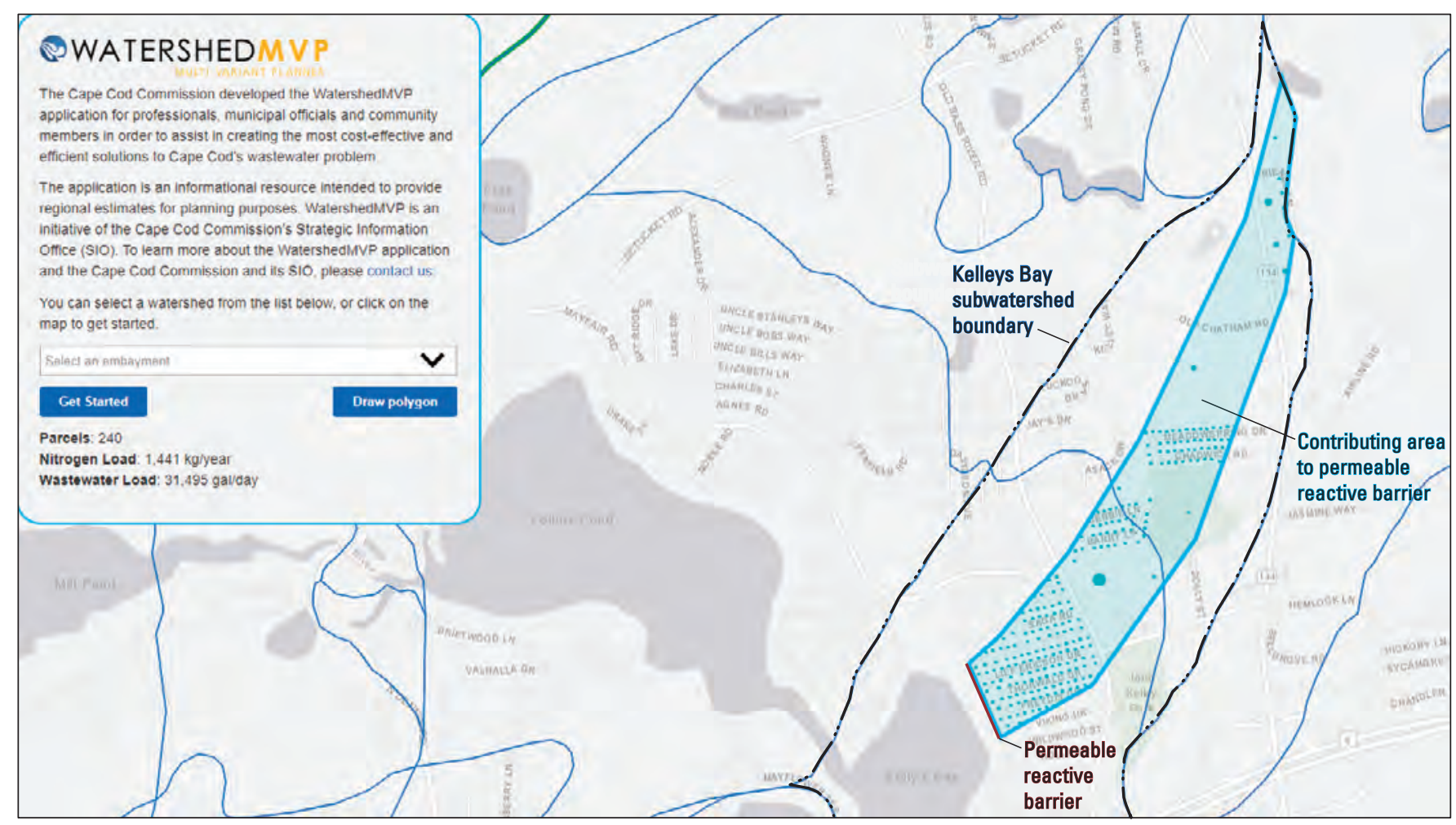

Figure 2. Screen shot from the Cape Cod Commission WatershedMVP application (version 3.1; http://www.watershedmvp.org/), showing the simulated subwatershed to Kelleys Bay and the contributing area to a potential permeable reactive barrier (PRB) at the Vinland Drive near Kelleys Bay site in Dennis, Massachusetts. Cyan dots represent the locations and magnitudes of nitrogen loading to the aquifer from septic systems in the PRB contributing area. 


\section{Site Investigations}

The onsite investigations were designed to be completed in two phases: an initial site investigation (ISI) followed, if required, by a full site investigation (FSI). The original site investigation specifications developed by the technical team are described in table 3 . The onsite investigations in this study were designed for potential PRBs of approximately 1,000 feet (ft; 305 meters [m]) in length, which was assumed to be a representative length for a full-scale PRB on Cape Cod. In practice, site investigations likely will be scale dependent, and differing amounts of data may be needed to characterize site conditions compared with the data needed for the 1,000-ft (305-m) length evaluated in this study.

\section{Initial Site Investigation}

The major objective of the ISI was to obtain site-specific data on depth to groundwater; horizontal and vertical hydraulic gradients and groundwater flow directions; groundwater flow rates; subsurface geologic conditions, particularly preliminary data on the presence of low-hydraulic-conductivity deposits; and water quality in shallow groundwater across the site and in a vertical profile at one site along the PRB treatment zone. The ISI specified by the technical team consisted of a minimum of three water-table wells, one continuous core, one vertical well cluster consisting of short (1-ft $[0.3-\mathrm{m}])$ screens at the core location, two rounds of hydraulic-head measurements, and two rounds of water-quality sample collection (table 3). The ISI data analysis focused on developing a preliminary conceptual model of hydrologic and water-quality conditions at the site-in particular, the concentrations and spatial variability of nitrogen - and calculating the nitrogen load (also referred to as nitrogen flux) to the treatment zone of a potential PRB at the site. This level of characterization was intended to be the minimum required to determine whether a site was hydrologically suitable for PRB installation. The potential effectiveness of PRBs installed at these sites was not evaluated in this study.

Five sites were selected for onsite investigations from the preliminary regional assessment of 27 sites nominated by Cape Cod towns. The assessment and selection were based primarily on the criteria listed in table 1. The sites at Prince Avenue near Prince Cove in Barnstable, Sailfish Drive near Bournes Pond in Falmouth, Herring Brook Way near Kescayo Gansett Pond (Lonnies Pond) in Orleans, Timber Landing Road near the Mashpee River in Mashpee, and Vinland Drive near Kelleys Bay in Dennis (fig. 1) were selected from the preliminary regional assessment as the most favorable locations for PRB installations. Detailed descriptions of these investigations are provided in Truslow and others $(2016,2017)$ and Truslow and Shanahan (2017) and summarized in the following sections of this report.

Table 3. Original specifications for initial and full site investigations to identify potential permeable reactive barrier sites for passive treatment of groundwater nitrogen on Cape Cod, Massachusetts.

[-, not applicable $]$

\begin{tabular}{|c|c|c|}
\hline Field task & Initial site investigation & Full site investigation \\
\hline Installation of shallow wells & Minimum of three wells & Minimum of three additional wells \\
\hline Installation of well clusters & $\begin{array}{l}\text { One well cluster consisting of approximately } \\
10 \text { wells }\end{array}$ & $\begin{array}{l}\text { Minimum of two additional well clusters consisting } \\
\text { of approximately } 10 \text { wells; priority locations along } \\
\text { permeable reactive barrier treatment zone }\end{array}$ \\
\hline Collection of continuous core & $\begin{array}{l}\text { One continuous core at well-cluster location; } \\
\text { maximum depth to freshwater/saltwater in- } \\
\text { terface or } 100 \text { feet ( } 30 \text { meters) if interface } \\
\text { not encountered }\end{array}$ & $\begin{array}{l}\text { Minimum of two continuous cores at additional well- } \\
\text { cluster locations; maximum depths same as initial } \\
\text { site investigation core }\end{array}$ \\
\hline Measurement of hydraulic head & $\begin{array}{l}\text { Minimum of two rounds of measurements } \\
\text { from all wells }\end{array}$ & $\begin{array}{l}\text { Minimum of one round of measurements from all } \\
\text { wells }\end{array}$ \\
\hline $\begin{array}{l}\text { Collection of water-quality samples } \\
\text { from wells }\end{array}$ & $\begin{array}{l}\text { Minimum of two rounds of sample collection } \\
\text { from all wells; initial site investigation } \\
\text { constituents listed in table } 4\end{array}$ & $\begin{array}{l}\text { Minimum of one round of sample collection from all } \\
\text { wells; full site investigation constituents listed in } \\
\text { table } 4\end{array}$ \\
\hline $\begin{array}{l}\text { Collection of water-quality samples } \\
\text { from receiving water body }\end{array}$ & - & Minimum of two samples \\
\hline $\begin{array}{l}\text { Measurement of hydraulic conduc- } \\
\text { tivity }\end{array}$ & - & $\begin{array}{l}\text { Minimum of } 10 \text { measurements from hydraulic tests } \\
\text { and } 10 \text { to } 15 \text { measurements from grain-size analysis }\end{array}$ \\
\hline
\end{tabular}




\section{Full Site Investigation}

The objectives of the FSI were to refine the site characterization and obtain the additional hydrologic information needed to design and install a PRB. The FSI specified by the technical team consisted of a minimum of three additional shallow wells, two additional continuous cores, two additional vertical well clusters consisting of short (1-ft [0.3-m]) screens at the core locations, one additional round of hydraulic-head measurements, measurements of hydraulic conductivity, installation of near-shore shallow wells in groundwater discharge areas, and one additional round of water-quality sample collection from all wells (table 3). The FSI data analysis was intended to refine the conceptual model developed from the ISI, including developing a more complete understanding of the spatial and temporal variability of hydrologic and water-quality conditions and improving the calculation of the nitrogen load through a potential PRB by using the additional data collected during the FSI.

The scope of this study allowed for only one site (Vinland Drive near Kelleys Bay in Dennis) to progress from an ISI to an FSI. The Vinland Drive site was selected because ISI results indicated that more of the preliminary regional assessment criteria (table 1) were met at this site than at the other ISI sites. Although the Vinland Drive site appeared to have the most favorable conditions based on the ISI results (for example, relatively high nitrate concentrations, adequate groundwater flow rates, a local groundwater flow direction perpendicular to the street, and relatively good access to drilling locations), three other sites (Prince Avenue near Prince Cove in Barnstable, Sailfish Drive near Bournes Pond in Falmouth, and Timber Landing Road near the Mashpee River in Mashpee) also held promise for PRB installation based on ISI results. The site at Herring Brook Way near Kescayo Gansett Pond (Lonnies Pond) in Orleans was determined to be unfavorable for PRB installation based on ISI results because of the prevalence of low-hydraulic-conductivity deposits. A detailed description of the FSI at the Vinland Drive site is provided in Truslow and others (2017) and summarized in the following sections of this report.

\section{Overview of Cape Cod Site Investigations}

Site characterizations require flexibility to respond to the local conditions encountered during an investigation. Consequently, the ISIs and FSIs originally specified by the technical team as minimal field programs required for site characterization (table 3) were not followed exactly during the Cape Cod site investigations. At all locations, more extensive investigations than what was specified in table 3 were conducted. The scopes of the actual investigations at the Cape Cod sites by WaterVision, LLC (Truslow and others, 2016, 2017; Truslow and Shanahan, 2017) are described briefly in the following sections.

\section{Installation of Shallow Monitoring Wells}

For the ISIs, networks of five to seven shallow (screened near the water table) monitoring wells were installed at each site to estimate local groundwater flow directions, horizontal hydraulic gradients, and shallow water-quality conditions. For the FSI at the Dennis site, several additional shallow monitoring wells were installed to improve estimates of local groundwater flow directions and rates. Wells were installed by using a direct-push drilling method and were constructed of 2-inch (5-centimeter $[\mathrm{cm}]$ )-diameter polyvinylchloride (PVC) casing fitted with 5-ft (1.5-m)-long well screens. All wells were surveyed to common horizontal and vertical datums (Truslow and others, 2016). Wells were sited in accessible areas that provided the best coverage possible for determining local hydrologic and water-quality conditions.

\section{Collection of Aquifer Materials}

For the ISIs, one continuous core was collected at each site with a direct-push drill rig. Cores were collected near the anticipated centers of the potential PRBs at the sites. Maximum cored depths ranged from 80 to $100 \mathrm{ft}$ (24 to $30 \mathrm{~m}$ ) below land surface at these sites. Drilling refusal limited core-collection depths at all sites except the Timber Landing Road near the Mashpee River at Mashpee site, where coring was advanced to the maximum specified depth of $100 \mathrm{ft}$ $(30 \mathrm{~m})$ below land surface. For the FSI at the Dennis site, an additional seven continuous cores were collected with a direct-push drill rig. Cores were collected along the potential PRB and at upgradient locations to determine the extent of a clay layer identified during the ISI. FSI core depths ranged from 63 to $66 \mathrm{ft}$ (19 to $20 \mathrm{~m}$ ) below land surface and were determined by the depth of a lower clay unit. The freshwater/saltwater interface was not encountered at any site, indicating that the interface was either below the refusal depth or not present at the site. Cores were logged onsite, and representative samples were collected and saved for future use (for example, grain-size analysis).

\section{Installation of Well Clusters}

For the ISIs, one well cluster was installed at the core location to measure the vertical hydraulic gradient and waterquality profile at each site. One-inch $(2.5-\mathrm{cm})$ inner-diameter PVC wells with $1-\mathrm{ft}[0.3-\mathrm{m}]-$ long well screens were installed with a direct-push drill rig. Screens were spaced evenly between the water table and bottom of the cored interval. The number of wells in each cluster ranged from 6 to 10 among the ISI sites. For the FSI at the Dennis site, four additional well clusters consisting of 2-inch $(5-\mathrm{cm})$ inner-diameter PVC wells (four to six wells per cluster) were installed at the continuous core locations.

\section{Measurement of Hydraulic Head}

For the ISIs, two rounds of groundwater-level measurements were collected at each site. Groundwater-level 
measurements also were collected from all wells during groundwater sampling events. For the FSI at the Dennis site, several additional rounds of groundwater-level measurements were collected. Surveyed measuring point altitudes were used to compute hydraulic heads relative to the North American Vertical Datum of 1988 (NAVD 88) or a local benchmark at the Mashpee and Orleans sites.

Measurements made in shallow wells during selected sampling rounds were used to prepare water-table maps and calculate horizontal hydraulic gradients. Measurements made in well clusters were used to compute vertical hydraulic gradients. These hydraulic-head data were used to determine local horizontal and vertical groundwater flow rates and directions.

At the Dennis site, tidal influence was observed on groundwater levels in the confined aquifer present at the site (Truslow and others, 2017). Continuous monitoring was carried out over a 3-month period at selected wells to determine the magnitude of tidal effects on groundwater levels. Accordingly, site-wide groundwater-level measurements were collected over a short period of time during the FSI to accurately determine groundwater flow directions and rates. Continuous monitoring was not carried out at the other sites; however, based on the reasonable groundwater flow patterns obtained from synoptic measurements, tidal effects were estimated to be minor.

\section{Collection of Water-Quality Samples}

For the ISIs, two rounds of water-quality samples were collected at each site. Samples were collected from all wells, resulting in the collection of approximately 15 samples per round at each site. Two rounds of samples were collected to obtain a preliminary measure of temporal variability at each ISI site. For the FSI at the Dennis site, two additional rounds of water-quality samples were collected.

The water-quality constituents measured for the ISI and FSI sampling events are listed in table 4 . This suite of constituents was selected to provide a broad understanding of water-quality conditions at the sites. Dissolved oxygen, oxidation-reduction (redox) potential, $\mathrm{pH}$, and specific conductance were measured in the field; all other constituents were analyzed in EPA-approved laboratories (Truslow and others, 2016, 2017). All analytical results and detailed descriptions of sample collection, quality assurance, and analytical procedures are provided in Truslow and others (2016, 2017). Selected water-quality constituents are summarized and discussed in this report.

\section{Estimation of Hydraulic Conductivity}

Slug tests and grain-size analysis were used to estimate the hydraulic conductivity of aquifer material at the Dennis site during the FSI (Truslow and others, 2017). The KozenyCarman and Alyamani and Sen methods (Halford and Kuniansky, 2002) were used to estimate hydraulic conductivity from grain-size analyses of aquifer sediments.
Table 4. Water-quality constituents measured in groundwater during initial and full site investigations to identify potential permeable reactive barrier sites for passive treatment of groundwater nitrogen on Cape Cod, Massachusetts.

Field constituents

\begin{tabular}{l} 
Dissolved oxygen \\
Oxidation-reduction potential \\
$\mathrm{pH}$ \\
Specific conductance \\
\hline \multicolumn{1}{c}{ Laboratory constituents } \\
\hline Total nitrogen \\
Ammonia \\
Nitrate \\
Nitrite \\
Orthophosphate \\
Dissolved organic carbon \\
Sulfate \\
Chloride \\
Alkalinity \\
Boron \\
Dissolved iron \\
Dissolved manganese \\
Dissolved arsenic \\
Nitrogen isotopes (full site investigation only) \\
\hline
\end{tabular}

\section{Site-Assessment Results}

Site-assessment results for the five Cape Cod sites selected for investigation are described in this section. Summaries of the preliminary regional assessment results include descriptions of selected characteristics of the subwatersheds and the potential PRB sites within the subwatersheds. Summaries of the investigations at the potential PRB sites include descriptions of well installations, generalized stratigraphy, flow directions and hydraulic gradients, and distributions of selected water-quality constituents. Selected well-construction, water-quality, and hydraulic-head data collected by WaterVision, LLC, are listed in tables 5 and 6.

Nitrogen loads were estimated with the WatershedMVP application and calculations using data collected during the site investigations (table 7). The WatershedMVP application was used to estimate the load to the groundwater-contributing area to the PRB as well as the total load from the watershed to the receiving water body, providing an estimate of the fraction of the total nitrogen load to the receiving water body that potentially would be treated by the PRB (table 7). The ISI and FSI data used to calculate nitrogen loads to potential PRB treatment zones included generalized stratigraphy, nitrate concentrations, and horizontal hydraulic gradients. 
Table 5. Initial site investigation well-construction specifications and selected water-quality and hydraulic-head results at sites investigated to determine hydrologic suitability for installation of permeable reactive barriers for passive treatment of groundwater nitrogen on Cape Cod, Massachusetts.

[Wells were installed and sampled by WaterVision, LLC (Truslow and others, 2016); water-quality and hydraulic-head data were collected during the second initial site investigation sampling round from April through May 2016. Well locations are shown in figures 3, 5, 7, 9, and 11. Data identified with a superscript "J" are values less than the quantitation limit but greater than zero. ft, foot; NAVD 88, North American Vertical Datum of 1988; mg/L, milligram per liter; $\mu \mathrm{S} / \mathrm{cm}$ at $25^{\circ} \mathrm{C}$, microsiemens per centimeter at 25 degrees Celsius; $\mathrm{N}$, nitrogen; $<$, less than detection limit; - insufficient water level to collect sample or sample not analyzed]

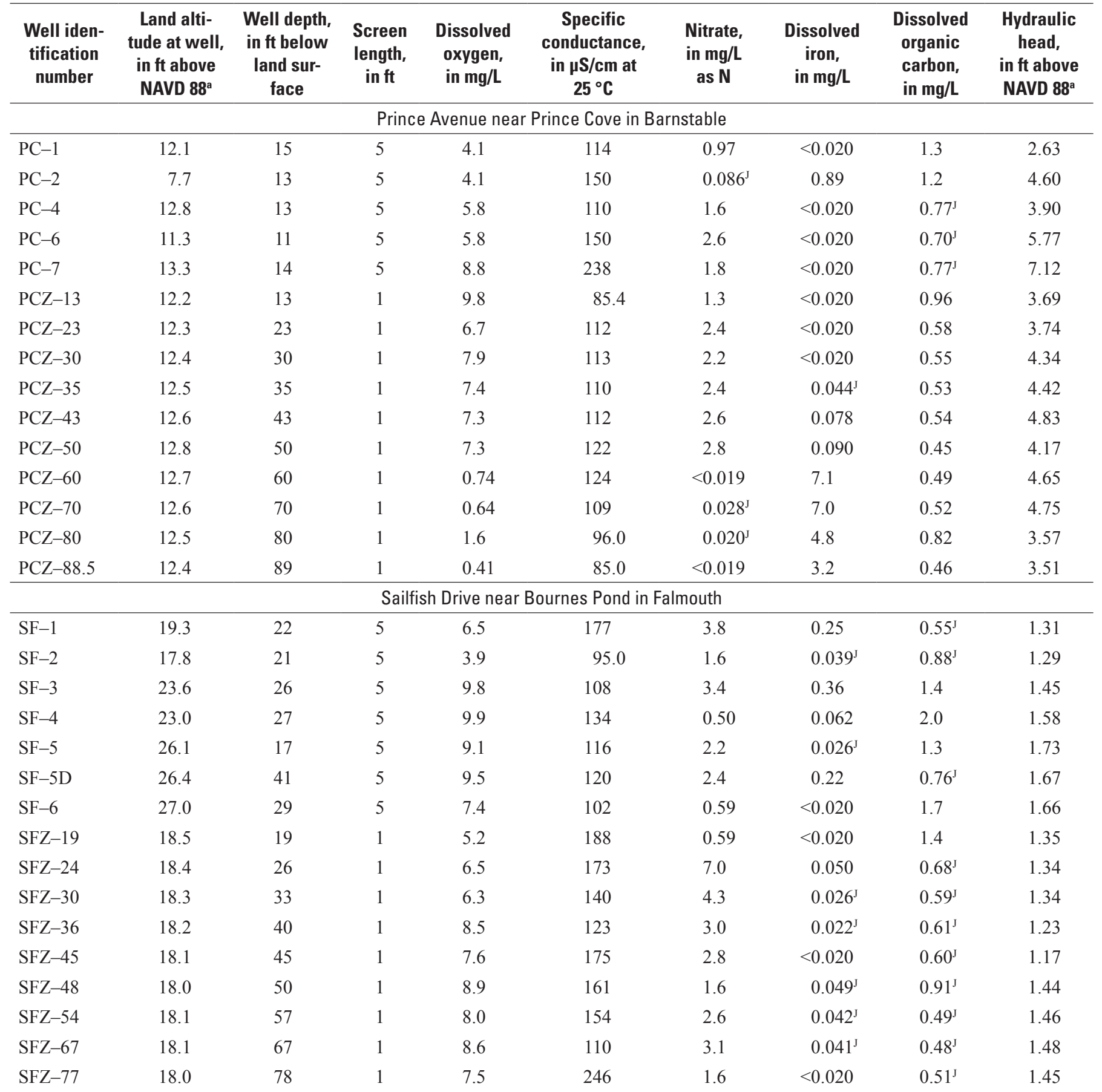


Table 5. Initial site investigation well-construction specifications and selected water-quality and hydraulic-head results at sites investigated to determine hydrologic suitability for installation of permeable reactive barriers for passive treatment of groundwater nitrogen on Cape Cod, Massachusetts.-Continued

[Wells were installed and sampled by WaterVision, LLC (Truslow and others, 2016); water-quality and hydraulic-head data were collected during the second initial site investigation sampling round from April through May 2016. Well locations are shown in figures 3, 5, 7, 9, and 11. Data identified with a superscript "J" are values less than the quantitation limit but greater than zero. ft, foot; NAVD 88, North American Vertical Datum of 1988; mg/L, milligram per liter; $\mu \mathrm{S} / \mathrm{cm}$ at $25^{\circ} \mathrm{C}$, microsiemens per centimeter at 25 degrees Celsius; $\mathrm{N}$, nitrogen; <, less than detection limit; —, insufficient water level to collect sample or sample not analyzed]

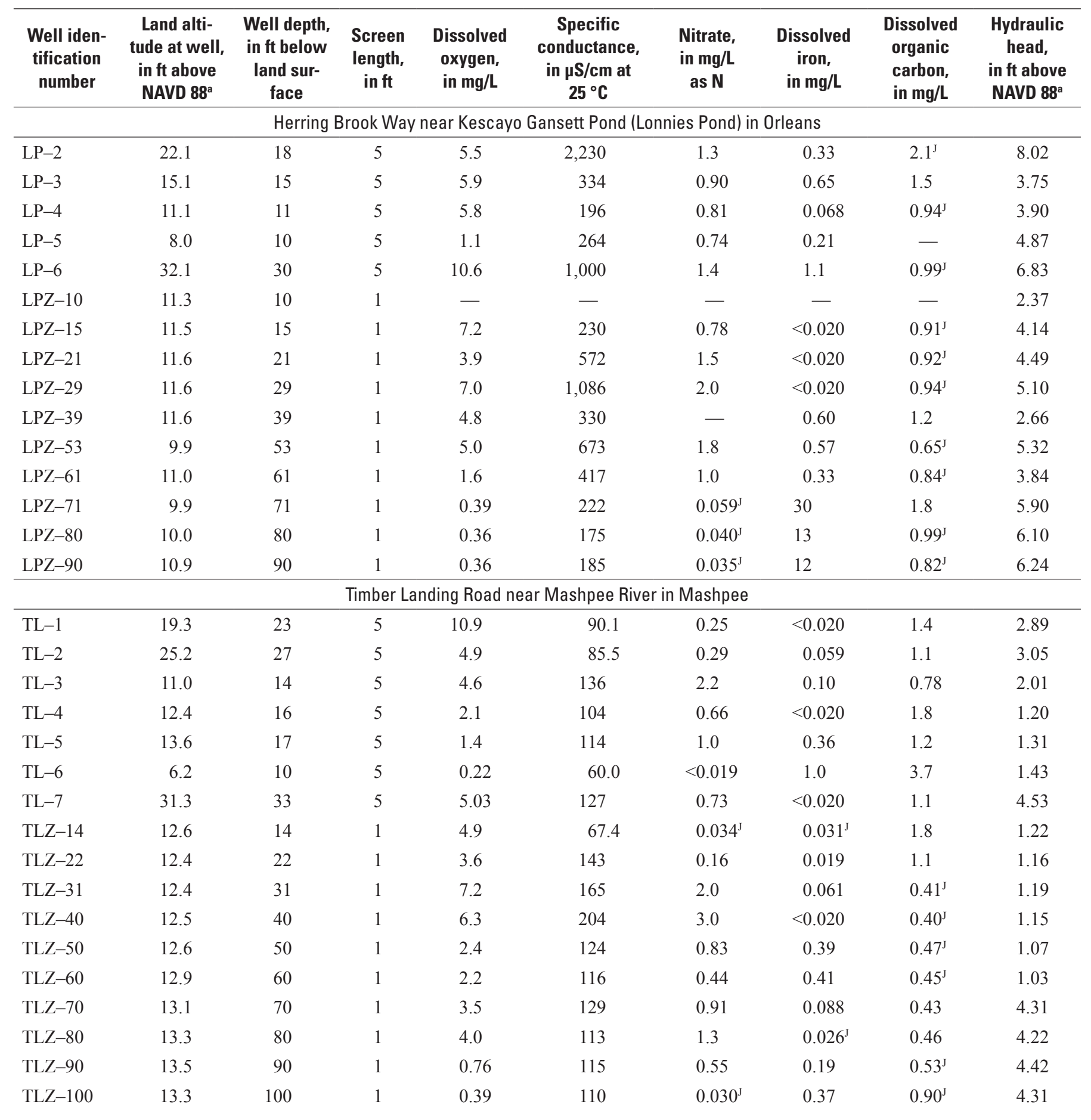


Table 5. Initial site investigation well-construction specifications and selected water-quality and hydraulic-head results at sites investigated to determine hydrologic suitability for installation of permeable reactive barriers for passive treatment of groundwater nitrogen on Cape Cod, Massachusetts.-Continued

[Wells were installed and sampled by WaterVision, LLC (Truslow and others, 2016); water-quality and hydraulic-head data were collected during the second initial site investigation sampling round from April through May 2016. Well locations are shown in figures 3, 5, 7, 9, and 11. Data identified with a superscript "J" are values less than the quantitation limit but greater than zero. ft, foot; NAVD 88, North American Vertical Datum of 1988; mg/L, milligram per liter; $\mu \mathrm{S} / \mathrm{cm}$ at $25^{\circ} \mathrm{C}$, microsiemens per centimeter at 25 degrees Celsius; $\mathrm{N}$, nitrogen; <, less than detection limit; —, insufficient water level to collect sample or sample not analyzed]

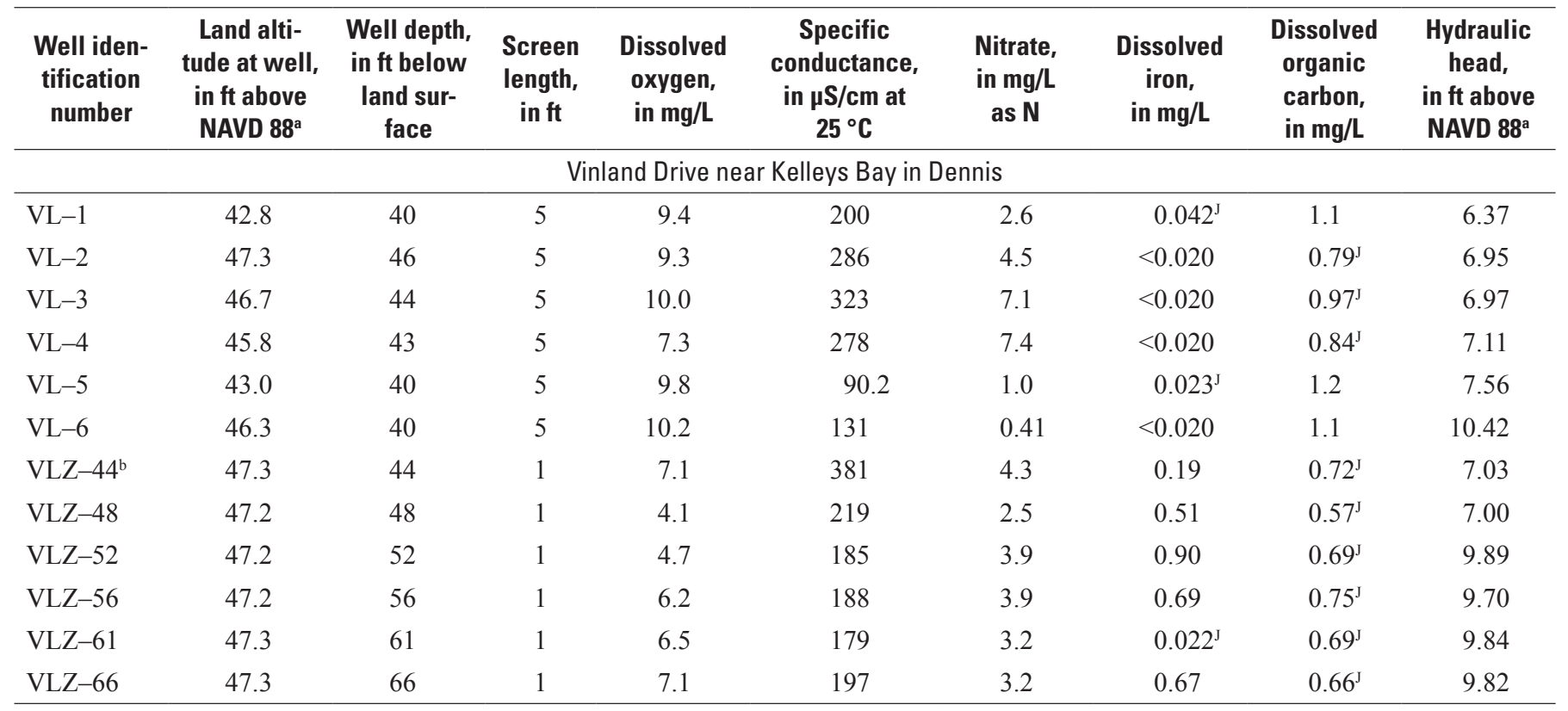

${ }^{a}$ Altitudes at the Mashpee and Orleans sites were determined by using estimated, local benchmarks rather than NAVD 88 benchmarks.

${ }^{\text {b} W a t e r-q u a l i t y ~ d a t a ~ a r e ~ f r o m ~ t h e ~ f i r s t ~ s a m p l i n g ~ r o u n d ~(f r o m ~ A p r i l ~ 2, ~ 2016) ~ b e c a u s e ~ t h e ~ g r o u n d w a t e r ~ l e v e l ~ w a s ~ t o o ~ l o w ~ d u r i n g ~ t h e ~ s e c o n d ~ s a m p l i n g ~ r o u n d . ~}$ 


\section{Hydrologic Site Assessment for Passive Treatment of Groundwater Nitrogen, Cape Cod, Massachusetts}

Table 6. Full site investigation well-construction specifications and selected water-quality and hydraulic-head results at the Vinland Drive near Kelleys Bay site in Dennis, Massachusetts.

[Wells were installed and sampled by WaterVision, LLC (Truslow and others, 2017); water-quality data were collected during the full site investigation sampling from December 2016 through January 2017. Hydraulic-head data were collected in May 2017. Well locations are shown in figure 13. Data identified with a superscript "J" are values less than the quantitation limit but greater than zero. ft, foot; NAVD 88, North American Vertical Datum of 1988; mg/L, milligram per liter; $\mu \mathrm{S} / \mathrm{cm}$ at $25{ }^{\circ} \mathrm{C}$, microsiemens per centimeter at 25 degrees Celsius; $\mathrm{N}$, nitrogen; <, less than detection limit;--, insufficient water level or yield to collect sample; NS, not sampled]

\begin{tabular}{|c|c|c|c|c|c|c|c|c|c|}
\hline $\begin{array}{l}\text { Well iden- } \\
\text { tification } \\
\text { number }\end{array}$ & $\begin{array}{c}\text { Land alti- } \\
\text { tude at well, } \\
\text { in ft above } \\
\text { NAVD } 88\end{array}$ & $\begin{array}{c}\text { Well depth, } \\
\text { in ft below } \\
\text { land sur- } \\
\text { face }\end{array}$ & $\begin{array}{c}\text { Screen } \\
\text { length, } \\
\text { in } \mathrm{ft}\end{array}$ & $\begin{array}{l}\text { Dissolved } \\
\text { oxygen, } \\
\text { in mg/L }\end{array}$ & $\begin{array}{c}\text { Specific } \\
\text { conductance, } \\
\text { in } \mu \mathrm{S} / \mathrm{cm} \text { at } \\
25^{\circ} \mathrm{C}\end{array}$ & $\begin{array}{c}\text { Nitrate, } \\
\text { in } \mathrm{mg} / \mathrm{L} \\
\text { as } \mathrm{N}\end{array}$ & $\begin{array}{l}\text { Dissolved } \\
\text { iron, } \\
\text { in } \mathrm{mg} / \mathrm{L}\end{array}$ & $\begin{array}{c}\text { Dissolved } \\
\text { organic } \\
\text { carbon, } \\
\text { in } \mathrm{mg} / \mathrm{L} \\
\end{array}$ & $\begin{array}{c}\text { Hydraulic } \\
\text { head, } \\
\text { in feet above } \\
\text { NAVD } 88 \\
\end{array}$ \\
\hline \multicolumn{10}{|c|}{ Upper sand unit } \\
\hline $\mathrm{VL}-1$ & 42.8 & 40 & 5 & 9.3 & 127 & 1.8 & $<0.010$ & $0.73^{\mathrm{J}}$ & 5.90 \\
\hline $\mathrm{VL}-2$ & 47.3 & 46 & 5 & 8.0 & 146 & 4.2 & $<0.010$ & $0.70^{\mathrm{s}}$ & 6.64 \\
\hline VLZ-44 & 47.3 & 44 & 1 & - & - & - & - & - & 6.67 \\
\hline VLZ-48 & 47.2 & 48 & 1 & 4.6 & 196 & 3.6 & $0.027^{\mathrm{J}}$ & 0.54 & 6.73 \\
\hline VL-3 & 46.7 & 44 & 5 & 9.5 & 320 & 4.2 & $0.030^{\mathrm{J}}$ & $0.85^{\mathrm{J}}$ & 6.62 \\
\hline $\mathrm{VL}-4$ & 45.8 & 43 & 5 & 9.2 & 186 & 7 & $<0.010$ & $0.69^{\mathrm{J}}$ & 6.68 \\
\hline VLZ-4a & 45.8 & 45 & 1 & 8.2 & 303 & 8.1 & $0.020^{\mathrm{J}}$ & $0.70^{\mathrm{J}}$ & 6.68 \\
\hline VL-5 & 43.0 & 40 & 5 & 9.4 & 136 & 1.7 & $<0.009$ & $0.63^{\mathrm{J}}$ & 6.99 \\
\hline VL-6 & 46.3 & 40 & 5 & 9.4 & 157 & 3.8 & $<0.010$ & $0.71^{\mathrm{J}}$ & 9.54 \\
\hline VLZ-6a & 46.3 & 41 & 1 & 9.3 & 195 & 2.8 & 0.54 & $0.83^{\mathrm{J}}$ & 9.50 \\
\hline VLZ-6b & 46.3 & 47 & 1 & 6.8 & 243 & 4.6 & 1.9 & $0.83^{\mathrm{J}}$ & 9.54 \\
\hline VL-7 & 42.9 & 40 & 5 & 9.6 & 204 & 2.4 & $0.036^{\mathrm{J}}$ & $0.63^{\mathrm{J}}$ & 7.82 \\
\hline VLZ-7a & 43.0 & 40 & 1 & 8.9 & 197 & 2.7 & 0.052 & $0.60^{\mathrm{s}}$ & 7.97 \\
\hline VL-8 & 48.0 & 46 & 5 & 8.4 & 406 & 7.5 & 0.26 & $0.98^{\mathrm{J}}$ & 10.35 \\
\hline VL-9 & 37.8 & 40 & 5 & 7.6 & 197 & 2.8 & 0.24 & $0.69^{\mathrm{J}}$ & 8.76 \\
\hline \multicolumn{10}{|c|}{ Lower sand unit } \\
\hline VL-1d & 42.7 & 63 & 10 & NS & NS & NS & NS & NS & 8.81 \\
\hline VL-2d & 47.4 & 62 & 10 & 8.0 & 189 & 4.4 & $<0.010$ & $0.53^{\mathrm{J}}$ & 9.04 \\
\hline VLZ-52 & 47.2 & 52 & 1 & 4.9 & 180 & 3.5 & $<0.009$ & $0.49^{\mathrm{J}}$ & 9.03 \\
\hline VLZ-56 & 47.2 & 56 & 1 & 5.4 & 177 & 3.6 & $0.010^{\mathrm{J}}$ & $0.79^{\mathrm{J}}$ & 9.08 \\
\hline VLZ-61 & 47.3 & 61 & 1 & 6.9 & 192 & 4.4 & $<0.009$ & $0.78^{\mathrm{J}}$ & 9.05 \\
\hline VLZ-66 & 47.3 & 66 & 1 & 6.5 & 200 & 3.7 & $<0.009$ & $0.54^{\mathrm{J}}$ & 9.09 \\
\hline VLZ-4b & 45.8 & 52 & 1 & 7.9 & 183 & 3.3 & $<0.009$ & $0.48^{\mathrm{J}}$ & 7.21 \\
\hline VLZ-4c & 45.9 & 58 & 1 & 8.4 & 176 & 4.9 & 0.53 & $0.51^{\mathrm{J}}$ & 9.18 \\
\hline VLZ-4d & 45.9 & 63 & 1 & 5.6 & 167 & 3.4 & 0.10 & $0.38^{\mathrm{J}}$ & 9.20 \\
\hline VLZ-6c & 46.3 & 58 & 1 & 7.0 & 189 & 4.2 & 0.34 & $0.45^{\mathrm{J}}$ & 9.70 \\
\hline VLZ-6d & 46.3 & 64 & 1 & 7.2 & 197 & 5.0 & 0.79 & $0.63^{\mathrm{J}}$ & 9.78 \\
\hline VLZ-7b & 43.0 & 53 & 1 & 7.3 & 206 & 3 & $<0.009$ & $0.44^{\mathrm{J}}$ & 8.98 \\
\hline VLZ-7c & 43.0 & 57 & 1 & - & - & - & - & - & 8.99 \\
\hline VLZ-7d & 43.1 & 61 & 1 & 5.8 & 156 & 2.1 & 0.37 & $0.37^{\mathrm{J}}$ & 9.25 \\
\hline $\mathrm{VL}-8 \mathrm{~d}$ & 48.0 & 65 & 10 & NS & NS & NS & NS & NS & 10.56 \\
\hline VL-9d & 37.9 & 61 & 10 & NS & NS & NS & NS & NS & 9.38 \\
\hline
\end{tabular}




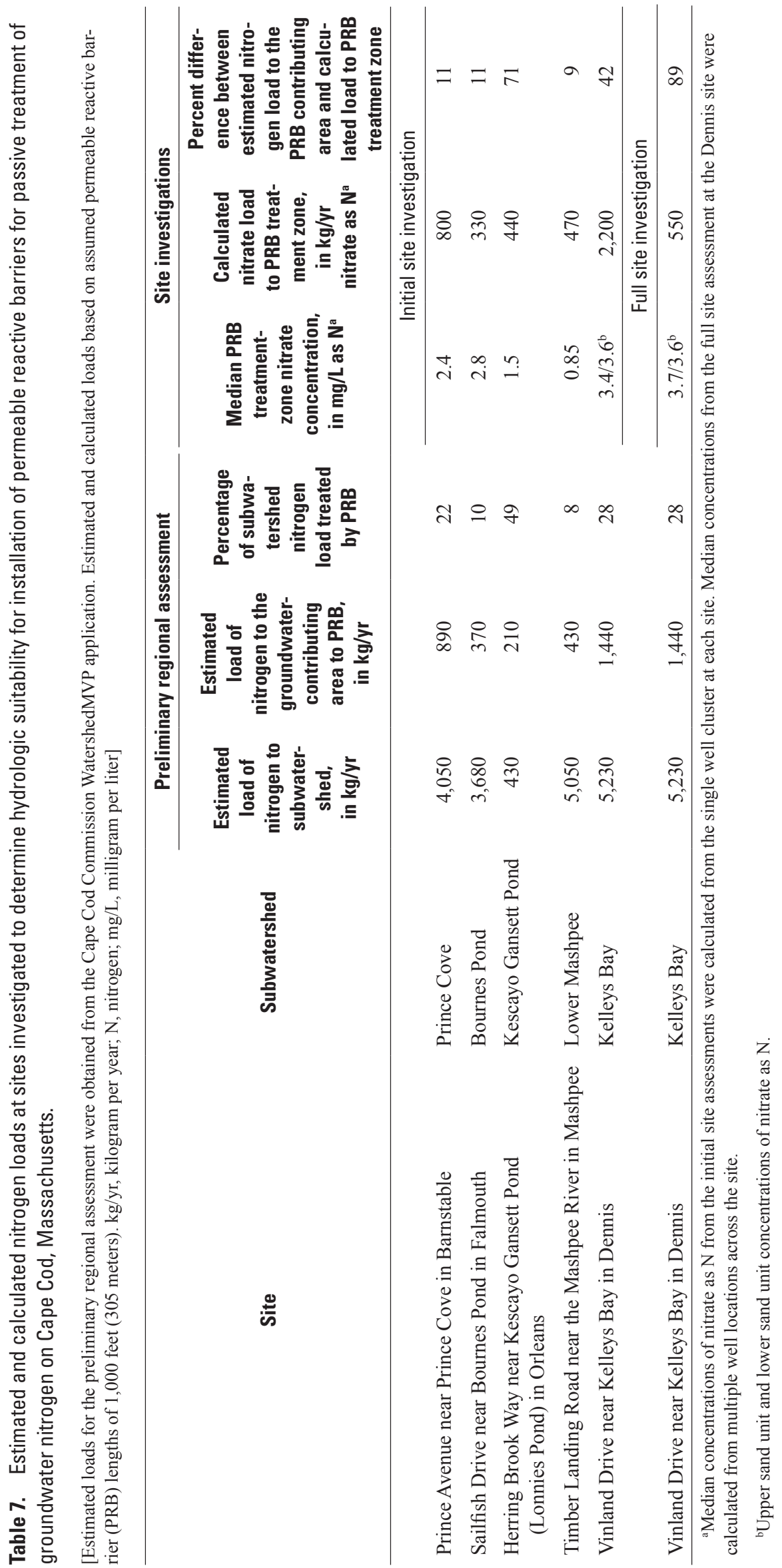


Nitrate as nitrogen loads were calculated from the product of concentration and groundwater flow rate by using the following equation:

$$
F=C q A,
$$

where

$$
\begin{gathered}
F \quad \text { is the nitrate as nitrogen load to the PRB } \\
\text { treatment zone, } \\
C \quad \text { is the median nitrate as nitrogen concentration } \\
\text { in groundwater, } \\
q \quad \text { is the specific discharge computed from } \\
\text { Darcy's law, and } \\
A \quad \text { is the area of the treatment zone perpendicular } \\
\text { to groundwater flow, which is determined } \\
\text { from site-specific hydrologic and water- } \\
\text { quality data. }
\end{gathered}
$$

Specific discharge, which is the product of the hydraulic conductivity and horizontal hydraulic gradient, is the volumetric flow rate per unit area per unit time. Medians of nitrate concentrations and hydraulic conductivities were used as measures of central tendency when a single, representative value was required for load calculations. Calculated loads then were compared with the loads estimated by using the WatershedMVP application (table 7). Nearly all nitrogen in groundwater at the Cape Cod sites was in the form of nitrate (Truslow and others, 2016, 2017). Consequently, the nitrogen loads estimated with the WatershedMVP application were assumed to be equivalent to nitrate as nitrogen and compared with the nitrate as nitrogen loads calculated with ISI and FSI data.

\section{Prince Avenue Near Prince Cove in Barnstable}

The Prince Avenue site borders the western edge of Prince Cove (fig. 3). Prince Cove is an embayment of the Marstons Mills River (location not shown), which flows south to West Bay and Cotuit Bay (fig. 1). Groundwater flow generally is to the east, toward Prince Cove and a salt marsh on the northern border of Prince Cove. The area to the west of (upgradient from) the site consists of low-density residential development and conservation land. Topographic relief in the area is relatively high; altitudes range from $10 \mathrm{ft}(3 \mathrm{~m})$ above sea level along Prince Avenue where a PRB could be installed to about $50 \mathrm{ft}(15 \mathrm{~m})$ above sea level in the upland areas to the west of the site. The distance to groundwater discharge areas from a PRB along Prince Avenue would range from 50 to more than $300 \mathrm{ft}$ (15 to more than $91 \mathrm{~m}$; fig. 3). Drilling access was affected by buried (gas, water, and storm sewer) and overhead (electric, cable, and telephone) utilities.

The area of the Prince Cove subwatershed is 1,189 acres (4.8 square kilometers $\left[\mathrm{km}^{2}\right]$ ). Land use in the subwatershed is dominated by residential development. All homes and businesses in the subwatershed use septic systems for wastewater disposal. Based on water use and nitrogen-loading rates in the WatershedMVP application, the estimated total load to the subwatershed from 460 properties and other sources is 4,050 kilograms per year ( $\mathrm{kg} / \mathrm{yr}$; table 7). The contributing area to the length of Prince Avenue that could contain a $1,000-\mathrm{ft}(305-\mathrm{m})$ PRB was estimated to be approximately one-quarter of the subwatershed area. The WatershedMVP application indicated that the estimated nitrogen load from 114 properties and other sources in the PRB contributing area is $890 \mathrm{~kg} / \mathrm{yr}$, or about 22 percent of the nitrogen load to the Prince Cove subwatershed. Approximately 86 percent of the wastewater load to the PRB contributing area is derived from single-family residential development.

Five water-table wells (PC-1, PC-2, PC-4, PC-6, and $\mathrm{PC}-7)$ and one well cluster (PCZ) consisting of ten 1-ft $(0.3-\mathrm{m})$ well screens were installed for the ISI (fig. 3$)$. The well screens in the cluster are set in the depth interval from 13 to $89 \mathrm{ft}$ (4 to $27 \mathrm{~m}$ ) below land surface (table 5). Well PC-7, which is upgradient from the PRB, was installed along Prince Avenue approximately $500 \mathrm{ft}(152 \mathrm{~m})$ from the northern end of the line of the rest of the wells along Prince Avenue. The continuous core collected from well cluster PCZ indicated that fine- to coarse-grained sand is present from land surface to $57.3 \mathrm{ft}(17.5 \mathrm{~m})$ below land surface, silty sand from 57.3 to $61.1 \mathrm{ft}$ ( 17.5 to $18.6 \mathrm{~m}$ ) below land surface, and fine- to coarse-grained sand from $61.1 \mathrm{ft}(18.6 \mathrm{~m})$ below land surface to the bottom of the core at $90 \mathrm{ft}(27.4 \mathrm{~m})$ below land surface (fig. 4).

In December 2016, an additional water-table well and well cluster were installed to supplement the ISI (Truslow and Shanahan, 2017). These wells (not shown) were installed to improve understanding of groundwater flow directions and gradients and the spatial distribution of water-quality constituents at the site. An additional round of water-level measurements and water-quality samples was collected from all wells between December 2016 and January 2017. Overall, the supplemental information did not substantially alter the geologic, hydrologic, and water-quality findings of the ISI. Consequently, the supplemental results are not discussed in this report. To provide consistent comparisons among the five sites in the study, only the results from the initial investigation in spring 2016 (ISI results) are summarized and discussed in this section.

Groundwater levels from the second ISI sampling round in April 2016 indicated that the water table along Prince Avenue is approximately $10 \mathrm{ft}(3 \mathrm{~m})$ below land surface or $4 \mathrm{ft}(1.2 \mathrm{~m})$ above sea level (fig. 3; table 5). Although the local configuration of the water table is not well defined because of the linear arrangement of wells along Prince Avenue and the location of upgradient well PC-7 (fig. 3), available data indicated that flow is nearly perpendicular to the shoreline of Prince Cove. The horizontal hydraulic gradient between wells PC -7 and PC -6 was 0.003 , and the vertical gradient at well cluster PCZ for the interval from 13 to $70 \mathrm{ft}$ (4 to $21 \mathrm{~m}$ ) below land surface, which spans the potential treatment zone, was 0.018 upward. The hydraulic gradient was downward below $70 \mathrm{ft}(21 \mathrm{~m})$ below land surface, which may reflect the influence of aquifer heterogeneity on groundwater flow 


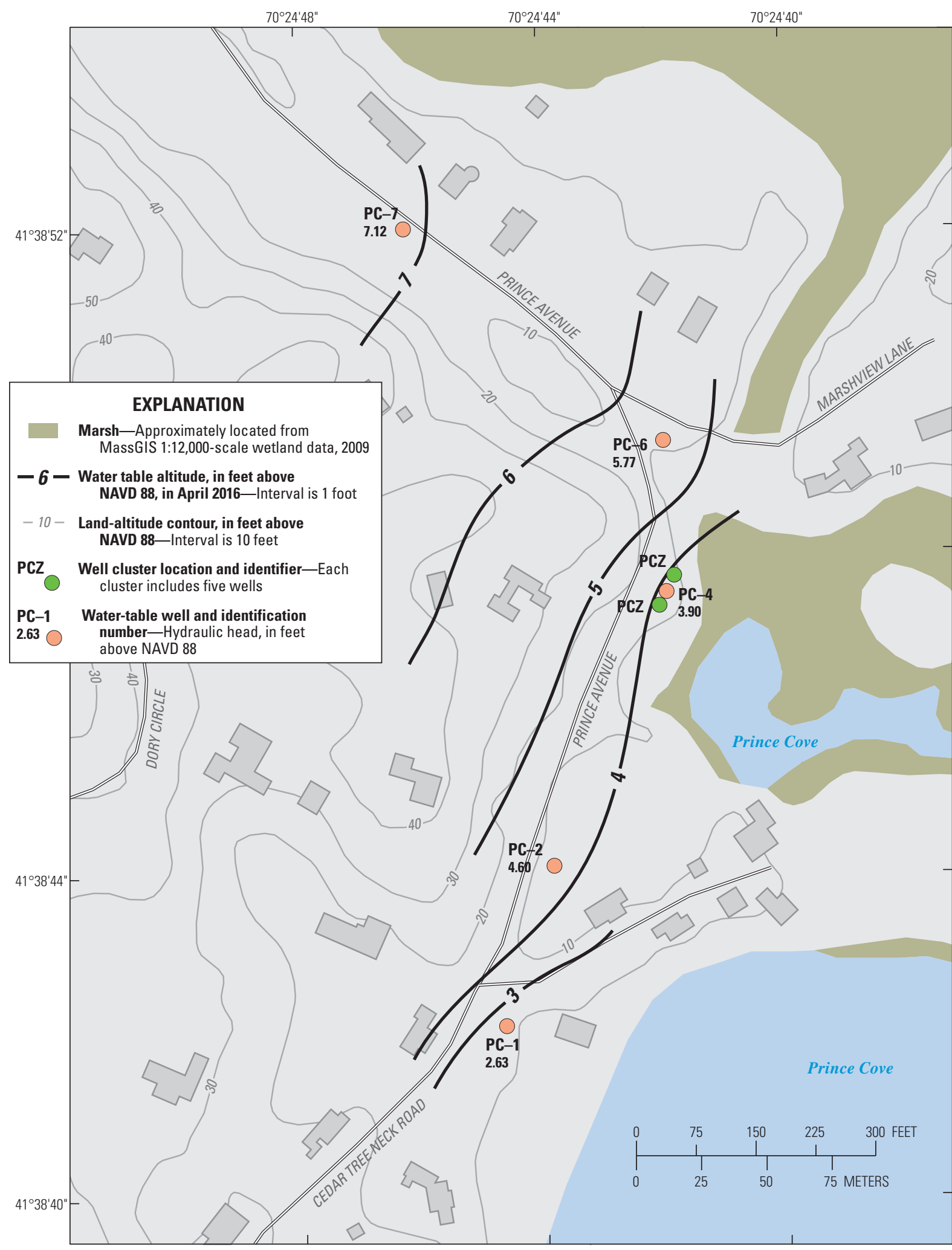

Base from Massachusetts Department of Transportation and

Massachusetts Bureau of Geographic Information (MassGIS) digital data

Massachusetts State Plane coordinate system

Lambert Conformal Conic projection

North American Datum of 1983

Figure 3. Topographic and hydrologic features, monitoring wells installed for the initial site investigation, and altitude of the water table at the Prince Avenue near Prince Cove site in Barnstable, Massachusetts. NAVD 88, North American Vertical Datum of 1988. 
$\boldsymbol{A}$

Specific conductance, in microsiemens per centimeter

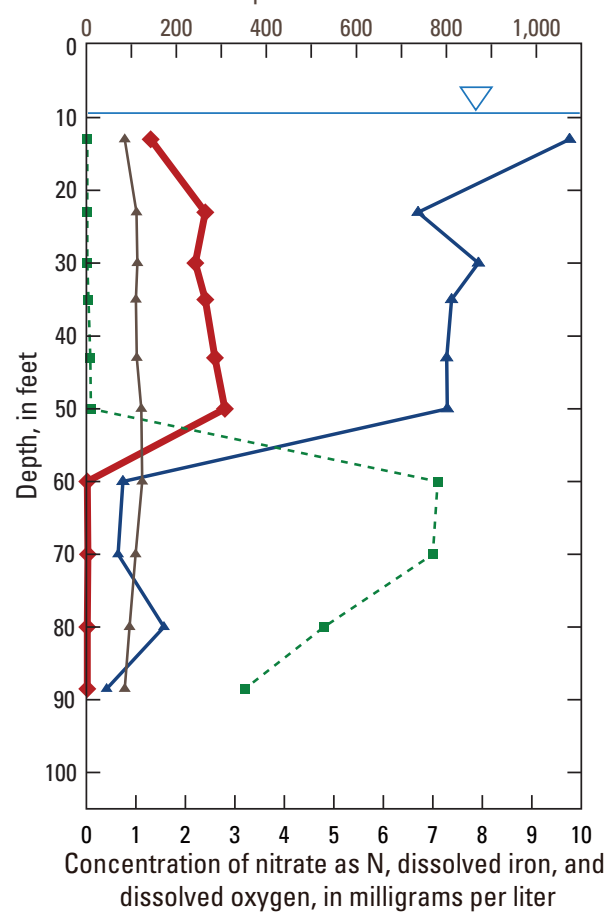

$\boldsymbol{B}$

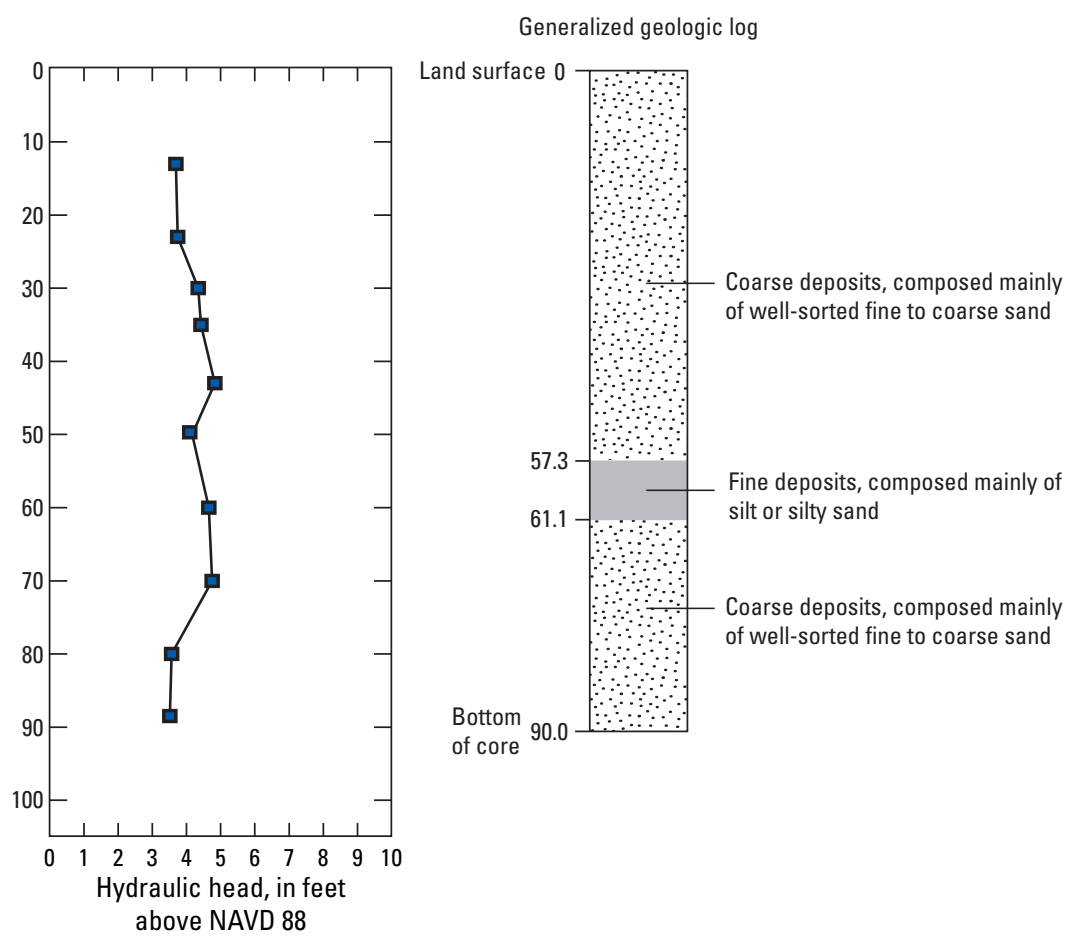

EXPLANATION

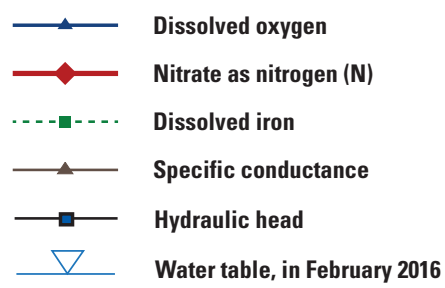

Figure 4. $A$, The vertical distributions of specific conductance, dissolved oxygen, dissolved iron, and nitrate as nitrogen in groundwater, $B$, the vertical distribution of hydraulic head, and $C$, the generalized stratigraphy at the Prince Avenue near Prince Cove site in Barnstable, Massachusetts. Water-quality data were collected in April 2016 for the initial site investigation.

directions. If the hydraulic conductivity of the sandy deposits in the potential treatment zone is assumed to be 220 feet per day (ft/d; 67 meters per day $[\mathrm{m} / \mathrm{d}]$ ), which is the median hydraulic conductivity from 11 aquifer tests conducted in the glacial stratified drift on Cape Cod (Masterson and Barlow, 1997), then the specific discharge in this zone is $0.66 \mathrm{ft} / \mathrm{d}$ $(0.20 \mathrm{~m} / \mathrm{d})$, assuming that the horizontal hydraulic gradient of 0.003 in shallow groundwater is representative of the entire treatment zone.

Data from the April 2016 sampling round are used to provide an overview of vertical and horizontal distributions of nitrate, dissolved oxygen, and dissolved iron at the site. Nitrate concentrations in samples from well cluster PCZ ranged from less than $(<) 0.019$ to 2.8 milligrams per liter (mg/L) as nitrogen (N) (fig. 4; table 5). Dissolved oxygen ranged from 0.41 to $9.8 \mathrm{mg} / \mathrm{L}$ and dissolved iron ranged from $<0.020$ to $7.1 \mathrm{mg} / \mathrm{L}$. Low dissolved oxygen and high dissolved iron concentrations from $60 \mathrm{ft}(18 \mathrm{~m})$ below land surface to the bottom of the well cluster are evidence that reducing conditions are present in this interval.

Nitrate concentrations also were low in this interval, which may reflect loss from nitrate-reducing reactions, such as denitrification, or lack of nitrate in recharging groundwater. Nitrate concentrations in samples from water-table wells, which represent spatial water-quality variability in shallow groundwater, were similar to concentrations in the well cluster, ranging from 0.086 to $2.6 \mathrm{mg} / \mathrm{L}$ nitrate as $\mathrm{N}$ (table 5); the value at the lower end of the range $(0.086 \mathrm{mg} / \mathrm{L})$ was less than the quantitation limit but greater than zero (as indicated by a superscript " $J$ " in table 5). Dissolved oxygen concentrations in shallow groundwater ranged from 4.4 to $8.8 \mathrm{mg} / \mathrm{L}$.

Groundwater was aerobic in all shallow samples, indicating that conditions in shallow groundwater are not conducive for naturally occurring denitrification. 
Lithologic and water-quality data from well cluster PCZ indicate that the upper $50 \mathrm{ft}(15 \mathrm{~m})$ of the saturated zone (10 to $60 \mathrm{ft}$ [3 to $18 \mathrm{~m}$ ] below land surface) would be the likely PRB treatment zone. Based on available data, which include a median well-cluster nitrate concentration in the potential treatment zone of $2.4 \mathrm{mg} / \mathrm{L}$ nitrate as $\mathrm{N}$, a specific discharge of $0.66 \mathrm{ft} / \mathrm{d}(0.020 \mathrm{~m} / \mathrm{d})$, and a 50 -by-1,000-ft (15-by-305-m) PRB treatment-zone area perpendicular to groundwater flow, the calculated load of nitrate to the PRB would be 2.2 kilograms per day $(\mathrm{kg} / \mathrm{d})$ nitrate as $\mathrm{N}$, or $800 \mathrm{~kg} / \mathrm{yr}$ nitrate as $\mathrm{N}$ (table 7).

\section{Sailfish Drive Near Bournes Pond in Falmouth}

The Sailfish Drive site borders the western edge of Bournes Pond (fig. 5), which is a saltwater estuary on Nantucket Sound (fig. 1). A tidal creek surrounded by salt marsh borders Sailfish Drive to the south. Groundwater near the site generally flows eastward toward Bournes Pond. Locally, groundwater may also flow to the south toward the tidal creek. A groundwater divide likely is present near the center of the peninsula formed by Green Pond to the west (fig. 1) and Bournes Pond to the east, limiting the size of the groundwater-contributing area to the site. The site is bordered to the west by a residential area developed in the early 1970s that contains closely spaced homes. Sailfish Drive curves away from Bournes Pond and consequently is not parallel to the pond along its entire length (fig. 5). The distance to groundwater discharge areas from a 1,000-ft (305 m) PRB along Sailfish Drive would range from about 200 to more than $500 \mathrm{ft}$ (61 to more than $152 \mathrm{~m}$; fig. 5). All utilities (gas, electric, cable, water, and storm sewers) along Sailfish Drive and Tarpon Road are underground, which limited access to locations for wells.

The area of the Bournes Pond subwatershed, which is present on both sides of the pond, is 1,165 acres $\left(4.7 \mathrm{~km}^{2}\right)$. Land use in the subwatershed is dominated by residential development. All homes and businesses in the subwatershed use septic systems for wastewater disposal. Based on the water use and nitrogen-loading rates in the WatershedMVP application, the estimated total load to the subwatershed from 670 properties and other sources is $3,680 \mathrm{~kg} / \mathrm{yr}$ (table 7). The contributing area to the $1,000-\mathrm{ft}(305-\mathrm{m})$ length of Sailfish Drive that would potentially contain a PRB was estimated to be about 4 percent of the total subwatershed area. The WatershedMVP application indicated that the nitrogen load to the PRB contributing area from 79 properties and other sources is $370 \mathrm{~kg} / \mathrm{yr}$, or about 10 percent of the total load to Bournes Pond from its subwatershed. Approximately 97 percent of the wastewater load to the PRB contributing area is derived from single-family residential development.

Six water-table wells (SF-1 through SF-6), one deep well associated with a water-table well (SF-5D), and one well cluster (SFZ) consisting of nine $1-\mathrm{ft}(0.3-\mathrm{m})$ well screens were installed for the ISI (fig. 5; table 5). Well screens in the cluster were set in the depth interval from 19 to $78 \mathrm{ft}$ (6 to $24 \mathrm{~m}$ ) below land surface. Two upgradient wells were installed along Tarpon Road and Sailfish Drive, approximately $400 \mathrm{ft}$ (122 m) from the curved end of Sailfish Drive where a PRB could be located. The continuous core collected from well cluster SFZ indicated that fine to coarse sand was present from land surface to $21.1 \mathrm{ft}(6.4 \mathrm{~m})$ below land surface, silty sand from 21.1 to $36.6 \mathrm{ft}$ ( 6.4 to $11.2 \mathrm{~m}$ ) below land surface, and fine to coarse sand from $36.6 \mathrm{ft}(11.2 \mathrm{~m})$ below land surface to the bottom of the core at $80 \mathrm{ft}(24.3 \mathrm{~m}$ ) below land surface (fig. 6).

Groundwater levels from the second sampling round in May 2016 indicated that the water table along Sailfish Drive is approximately $18 \mathrm{ft}(5.5 \mathrm{~m})$ below land surface or $1 \mathrm{ft}(0.3 \mathrm{~m})$ above sea level (fig. 5; table 5). Available data indicated that flow is nearly perpendicular to the shoreline of Bournes Pond. The water table is relatively flat in this area. The horizontal hydraulic gradient between wells SF-6 and SF-2 was 0.0009 , and the vertical gradient at well cluster SFZ over the interval from 19 to $78 \mathrm{ft}$ (6 to $24 \mathrm{~m}$ ) below land surface, which spans the potential treatment zone, was 0.0015 upward. Downward gradients also were observed in the center of the vertical interval, which may reflect the influence of aquifer heterogeneity on groundwater flow directions. Using the median hydraulic conductivity of $220 \mathrm{ft} / \mathrm{d}(67 \mathrm{~m} / \mathrm{d})$ for the glacial stratified drift on Cape Cod (Masterson and Barlow, 1995), the specific discharge in this zone is $0.20 \mathrm{ft} / \mathrm{d}(0.060 \mathrm{~m} / \mathrm{d})$, assuming that the horizontal hydraulic gradient of 0.0009 in shallow groundwater is representative of the entire treatment zone.

Data from the May 2016 sampling round are used to provide an overview of vertical and horizontal distributions of nitrate, dissolved oxygen, and dissolved iron at the site. Nitrate concentrations in samples from well cluster SFZ ranged from 0.59 to $7.0 \mathrm{mg} / \mathrm{L}$ nitrate as $\mathrm{N}$ (fig. 6; table 5). A peak in nitrate concentrations was present in the depth interval from 20 to $40 \mathrm{ft}$ ( 6 to $12 \mathrm{~m}$ ) below land surface. Dissolved oxygen ranged from 5.2 to $8.9 \mathrm{mg} / \mathrm{L}$, and dissolved iron concentrations did not exceed $0.05 \mathrm{mg} / \mathrm{L}$. Nitrate concentrations in samples from water-table wells, which represent spatial water-quality variability in shallow groundwater, were lower than concentrations in the upper part of the well cluster, ranging from 0.59 to $3.8 \mathrm{mg} / \mathrm{L}$ nitrate as $\mathrm{N}$ (table 5). This finding may indicate that the nitrate peak in the well cluster is not representative of the entire potential PRB treatment zone. Dissolved oxygen concentrations in shallow groundwater ranged from 3.9 to $9.9 \mathrm{mg} / \mathrm{L}$. Groundwater was aerobic in all samples, indicating that conditions are not conducive for naturally occurring denitrification at this site.

Stratigraphic and water-quality data from well cluster SFZ indicate that the entire $60-\mathrm{ft}(18 \mathrm{~m})$ vertical interval from the water table to $80 \mathrm{ft}(24 \mathrm{~m})$ below land surface potentially would be the PRB treatment zone at this site. Alternatively, treatment could be focused on the upper $30 \mathrm{ft}(9 \mathrm{~m})$ of the saturated zone, where nitrate concentrations appear to be highest. As is the case for all the sites, additional data to determine nitrate concentrations across the entire proposed length of the PRB would provide a more accurate estimate of the vertical extent of the treatment zone and potential nitrogen load 


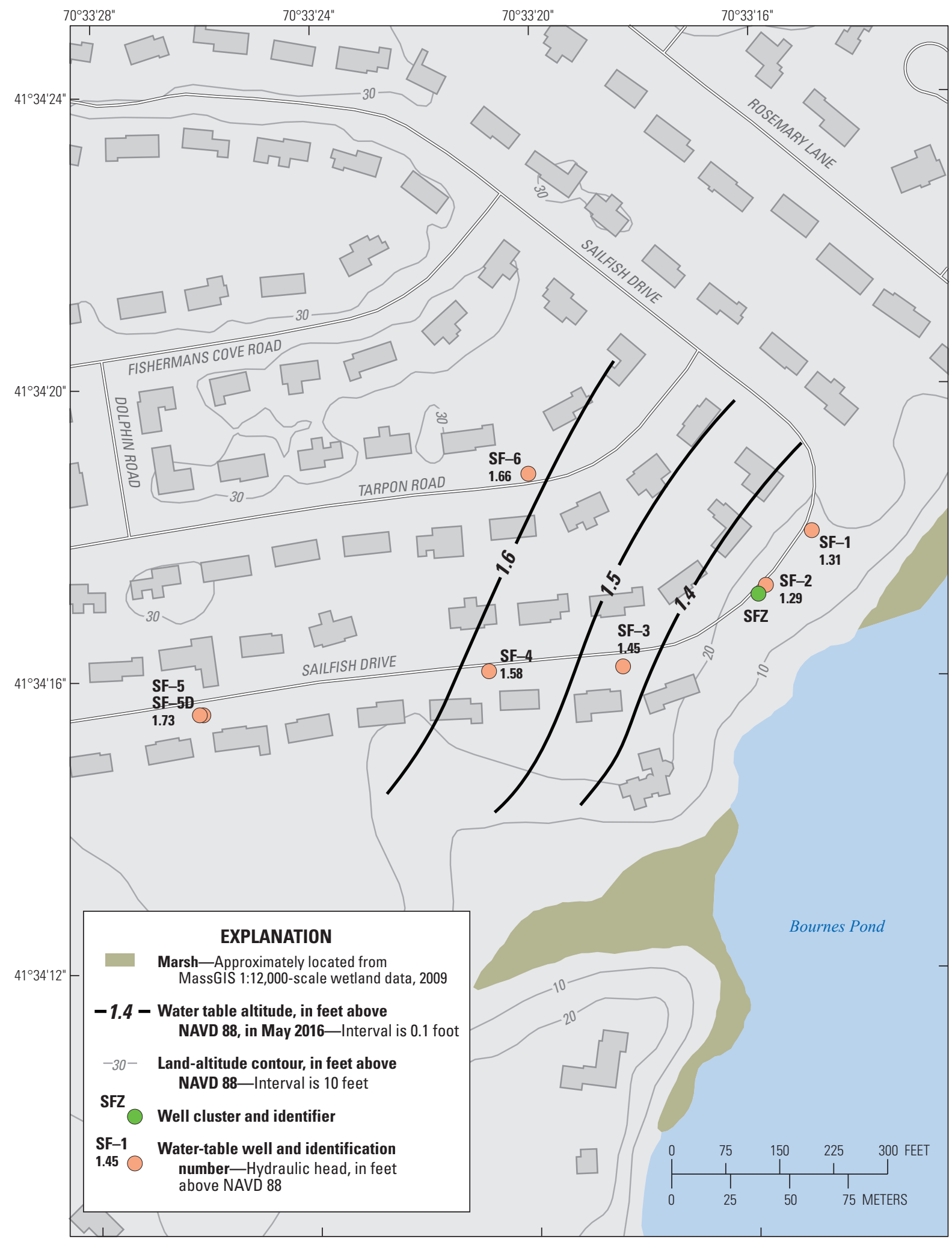

Base from Massachusetts Department of Transportation and

Massachusetts Bureau of Geographic Information (MassGIS) digital data

Massachusetts State Plane coordinate system

Lambert Conformal Conic projection

North American Datum of 1983

Figure 5. Topographic and hydrologic features, monitoring wells installed for the initial site investigation, and altitude of the water table at the Sailfish Drive near Bournes Pond site in Falmouth, Massachusetts. 
$\boldsymbol{A}$ Specific conductance, in microsiemens per centimeter

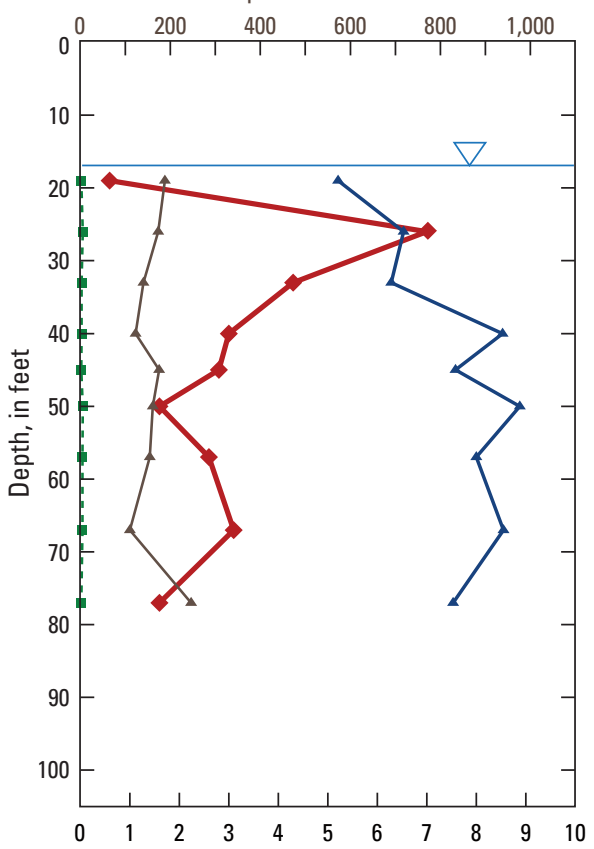

Concentration of nitrate as $\mathrm{N}$, dissolved iron, and dissolved oxygen, in milligrams per liter
B

C

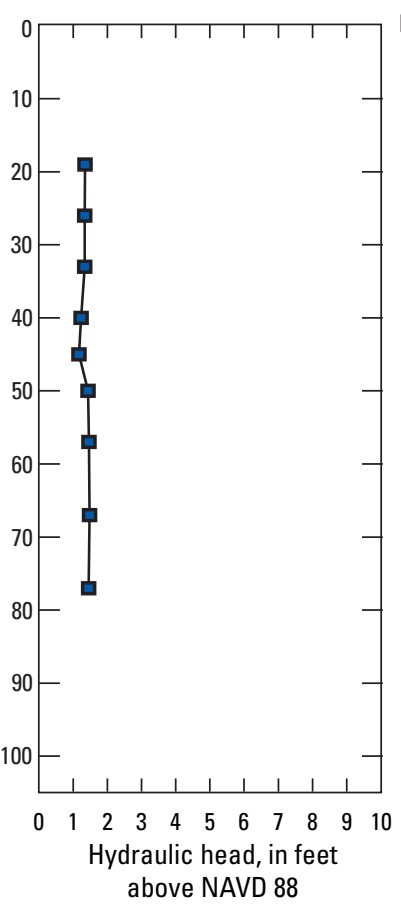

\section{EXPLANATION}

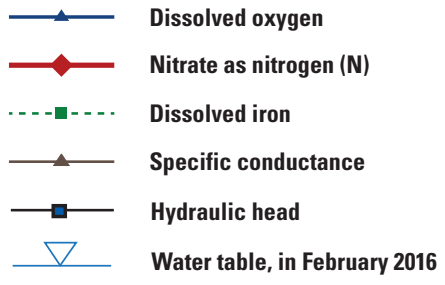

Figure 6. A, The vertical distributions of specific conductance, dissolved oxygen, dissolved iron, and nitrate as nitrogen in groundwater, $B$, the vertical distribution of hydraulic head, and $C$, the generalized stratigraphy at the Sailfish Drive near Bournes Pond site in Falmouth, Massachusetts. Water-quality data were collected in May 2016 for the initial site investigation. 
reduction in response to PRB installation. Based on available data, which include a median well-cluster nitrate concentration in the potential treatment zone of $2.8 \mathrm{mg} / \mathrm{L}$ nitrate as $\mathrm{N}$, a specific discharge of $0.20 \mathrm{ft} / \mathrm{d}(0.060 \mathrm{~m} / \mathrm{d})$, and a 60 -by-1,000-ft (18-by-305-m) PRB treatment-zone area perpendicular to groundwater flow, the calculated nitrate load to the PRB would be $0.9 \mathrm{~kg} / \mathrm{d}$ nitrate as $\mathrm{N}$, or $330 \mathrm{~kg} / \mathrm{yr}$ nitrate as $\mathrm{N}$ (table 7).

\section{Herring Brook Way Near Kescayo Gansett Pond (Lonnies Pond) in Orleans}

The Herring Brook Way site borders the western edge of Kescayo Gansett Pond (Lonnies Pond; fig. 7), which is a tidally influenced saltwater pond that drains to Pleasant Bay (fig. 1). Groundwater near the site flows eastward towards Kescayo Gansett Pond (fig. 7). However, more regionally, groundwater also discharges to two nearby freshwater ponds, Crystal Lake and Pilgrim Lake (location not shown), affecting upgradient groundwater flow directions. Groundwater flow to these lakes limits the size of the subwatershed for Kescayo Gansett Pond. Development on the upgradient (western) side of the site consists mostly of widely spaced houses. Houses are also present on the eastern side of Herring Brook Way, between the road and the pond, which would place them downgradient from a PRB installation along the road. The distance to groundwater discharge areas from a 1,000-ft (305-m) PRB along Herring Brook Way would be approximately $250 \mathrm{ft}$ (76 m; fig. 7). Drilling access was affected by underground (water and storm sewer) and overhead (electric, cable, and telephone) utilities.

The area of the Kescayo Gansett Pond subwatershed is 331 acres $\left(1.34 \mathrm{~km}^{2}\right)$. Land use in the subwatershed is dominated by a mix of single-family and multifamily residential development. All homes and businesses in the subwatershed use septic systems for wastewater disposal. Based on water use and nitrogen-loading rates in the WatershedMVP application, the estimated total nitrogen load to the subwatershed from 97 properties and other sources is $430 \mathrm{~kg} / \mathrm{yr}$ (table 7). The contributing area to the length of Herring Brook Way that could contain a 1,000-ft (305-m) PRB was estimated to be approximately 75 percent of the total subwatershed area. Data from the WatershedMVP application indicated that the estimated nitrogen load to the PRB contributing area from 39 properties and other sources was $210 \mathrm{~kg} / \mathrm{yr}$, or about 49 percent of the total load to Kescayo Gansett Pond from its subwatershed. Approximately 71 percent of the wastewater load to the PRB contributing area is derived from singlefamily residential development.

Five water-table wells (LP-2 through LP-6) and one well cluster (LPZ) consisting of ten 1-ft $(0.3-\mathrm{m})$ well screens were installed for the ISI (fig. 7; table 5). Well screens in the cluster are in the depth interval from 10 to $90 \mathrm{ft}$ (3 to $27 \mathrm{~m}$ ) below land surface. One upgradient well was installed along Monument Road, approximately $200 \mathrm{ft}(61 \mathrm{~m})$ from the wells along Herring Brook Way where a PRB could be located. The continuous core collected from well cluster LPZ indicated that there was more vertical aquifer heterogeneity and fine-grained material at this site than the other ISI sites. Fine-grained deposits (mainly silt or silty sand) were present from land surface to $10.3 \mathrm{ft}(3.1 \mathrm{~m})$ below land surface and from 20.4 to $70 \mathrm{ft}$ (6.2 to $21.3 \mathrm{~m}$ ) below land surface; fine to coarse sand was present from 10.3 to $20.4 \mathrm{ft}$ ( 3.1 to $6.2 \mathrm{~m}$ ) below land surface and from $70 \mathrm{ft}(21.3 \mathrm{~m})$ below land surface to the bottom of the core at $90 \mathrm{ft}(27.4 \mathrm{~m}$ ) below land surface (fig. 8).

Groundwater levels from the second sampling round in May 2016 indicated that the water table along Herring Brook Way was approximately $8 \mathrm{ft}(2.4 \mathrm{~m})$ below land surface or $4 \mathrm{ft}(1.2 \mathrm{~m})$ above sea level (fig. 7; table 5). Available data indicated that flow is nearly perpendicular to the shoreline of Kescayo Gansett Pond. Based on limited data, the horizontal hydraulic gradient at this site is relatively steep. The horizontal hydraulic gradient between wells LP-6 and LP -4 was 0.012 , and the vertical gradient in the 10- to $90-\mathrm{ft}$ (3- to $27-\mathrm{m}$ ) below land surface interval in well cluster PLZ, which spans the entire potential treatment zone, was 0.048 upward. Downward gradients also were observed in parts of the vertical interval, which may reflect the influence of aquifer heterogeneity on groundwater flow directions. If the hydraulic conductivity of the fine-grained deposits in the potential treatment zone is assumed to be $40 \mathrm{ft} / \mathrm{d}(13 \mathrm{~m} / \mathrm{d})$, which is the lowest value from 11 aquifer tests in the glacial stratified drift on Cape Cod (Masterson and Barlow, 1995), then the specific discharge in this zone is $0.5 \mathrm{ft} / \mathrm{d}(0.15 \mathrm{~m} / \mathrm{d})$, assuming that the horizontal hydraulic gradient of 0.012 in shallow groundwater is representative of the entire treatment zone.

Data from the May 2016 sampling round were used to provide an overview of vertical and horizontal distributions of nitrate, dissolved oxygen, and dissolved iron at the site (table 5). Nitrate concentrations in samples from well cluster LPZ ranged from 0.035 (less than the quantitation limit but greater than 0 ) to $2.0 \mathrm{mg} / \mathrm{L}$ nitrate as $\mathrm{N}$ (fig. 8; table 5). Dissolved oxygen ranged from 0.36 to $7.2 \mathrm{mg} / \mathrm{L}$, and dissolved iron ranged from $<0.020$ to $30 \mathrm{mg} / \mathrm{L}$. Low dissolved oxygen and high dissolved iron concentrations from $60 \mathrm{ft}(18 \mathrm{~m})$ below land surface to the bottom of the well cluster may indicate that reducing conditions are present in this interval. Nitrate concentrations also are low in this interval, which may reflect a lack of nitrate in recharging groundwater or loss from nitrate-reducing reactions such as denitrification. Nitrate concentrations in samples from water-table wells, which represent spatial water-quality variability in shallow groundwater, were similar to concentrations in the upper part of the well cluster, ranging from 0.74 to $1.4 \mathrm{mg} / \mathrm{L}$ nitrate as $\mathrm{N}$ (table 5). Dissolved oxygen concentrations in shallow groundwater ranged from 1.1 to $10.5 \mathrm{mg} / \mathrm{L}$. Therefore, conditions are not conducive for naturally occurring denitrification in the shallow zone that contains elevated nitrate concentrations.

Water-quality data indicate that the $60-\mathrm{ft}(18-\mathrm{m})$ vertical interval from the water table to $70 \mathrm{ft}(21 \mathrm{~m})$ below land surface potentially would be the PRB treatment zone at this site. However, the prevalence of fine-grained deposits in 


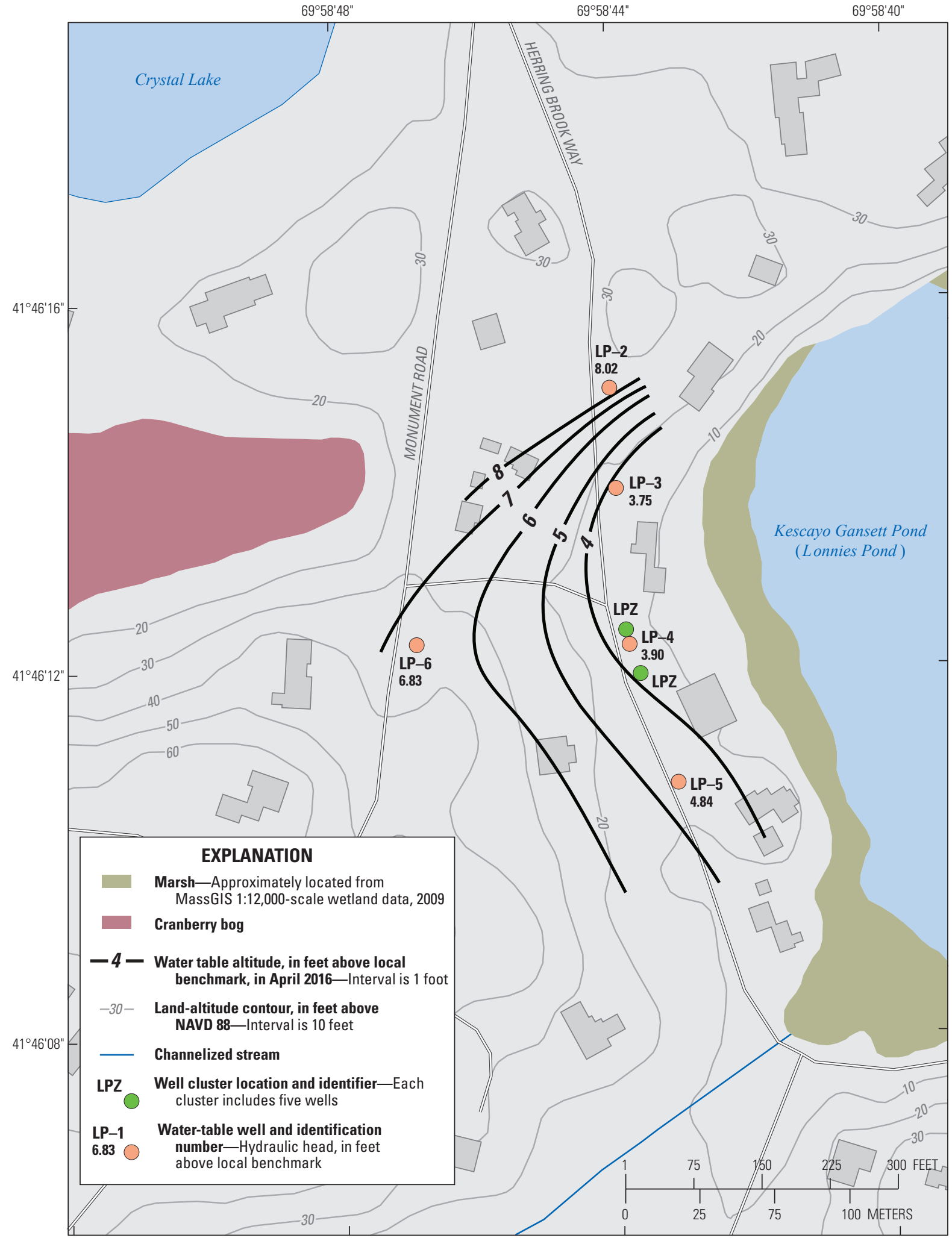

Base from Massachusetts Department of Transportation and

Massachusetts Bureau of Geographic Information (MassGIS) digital data

Massachusetts State Plane coordinate system

Lambert Conformal Conic projection

North American Datum of 1983

Figure 7. Topographic and hydrologic features, monitoring wells installed for the initial site investigation, and altitude of the water table at the Herring Brook Way near Kescayo Gansett Pond (Lonnies Pond) site in Orleans, Massachusetts. 
$\boldsymbol{A}$ Specific conductance, in microsiemens per centimeter

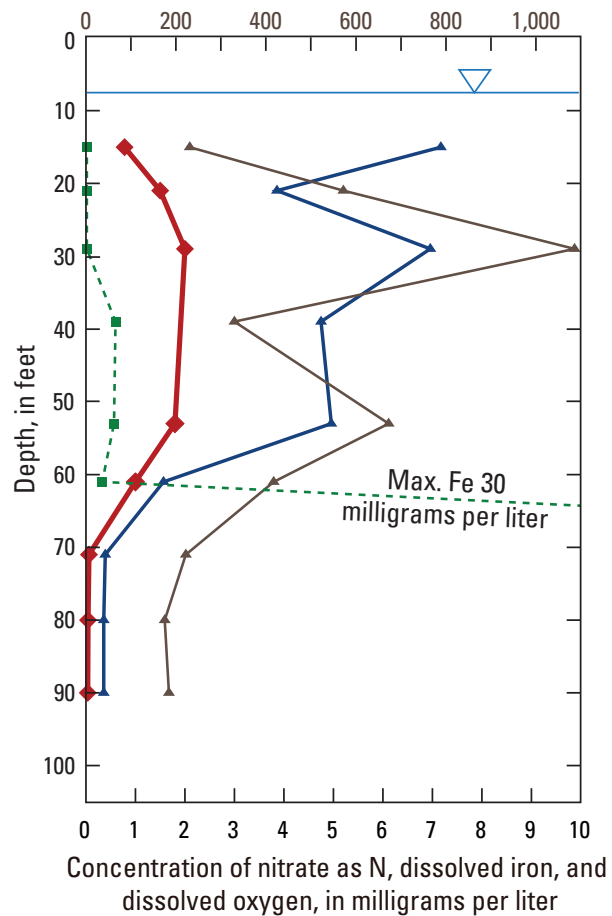

B

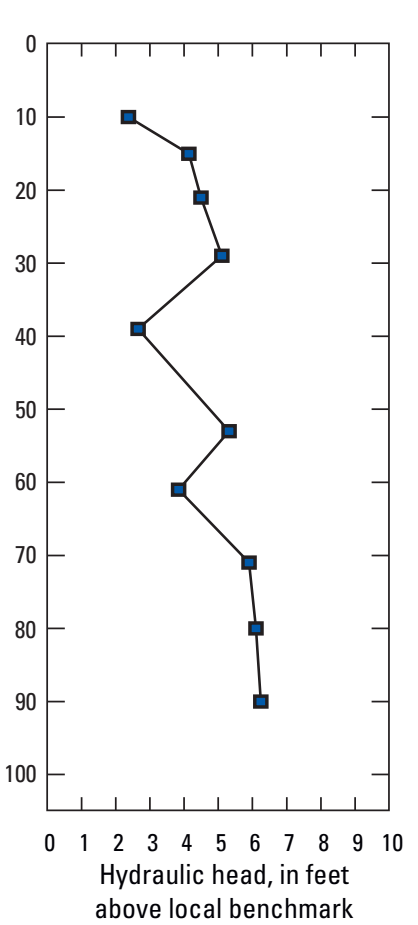

C

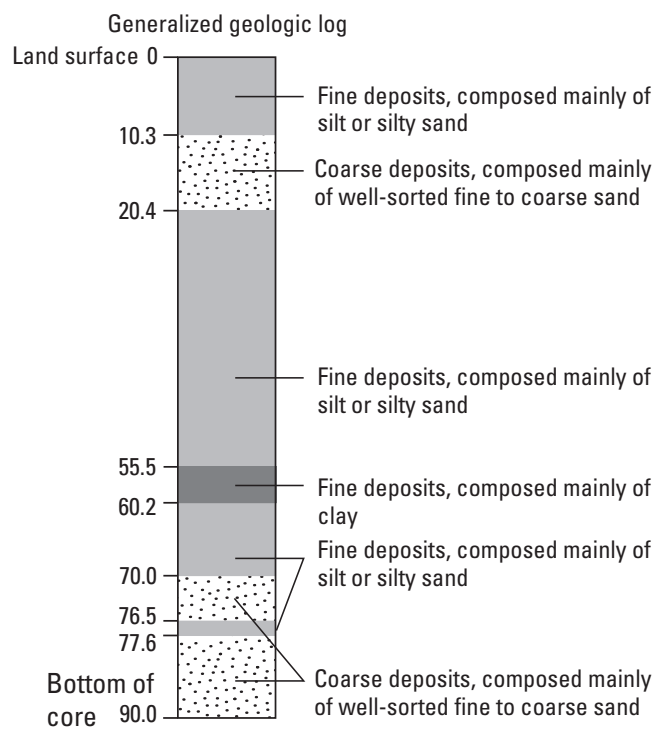

EXPLANATION

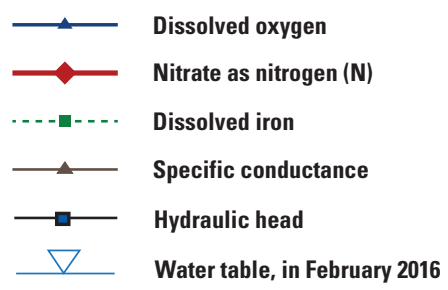

Figure 8. $A$, The vertical distributions of specific conductance, dissolved oxygen, dissolved iron, and nitrate as nitrogen in groundwater, $B$, the vertical distribution of hydraulic head, and $C$, the generalized stratigraphy at the Herring Brook Way near Kescayo Gansett Pond (Lonnies Pond) site in Orleans, Massachusetts. Water-quality data were collected in May 2016 for the initial site investigation. Max., maximum. 
this interval, if extensive, could be an impediment to PRB installation. Based on available data, which include a median well-cluster nitrate concentration in the potential treatment zone of $1.5 \mathrm{mg} / \mathrm{L}$ nitrate as $\mathrm{N}$, a specific discharge of $0.5 \mathrm{ft} / \mathrm{d}$ $(0.15 \mathrm{~m} / \mathrm{d})$, and a 60 -by-1,000-ft (18-by-305-m) PRB treatment-zone area perpendicular to groundwater flow, the nitrate load to the PRB would be $1.2 \mathrm{~kg} / \mathrm{d}$ nitrate as N, or $440 \mathrm{~kg} / \mathrm{yr}$ nitrate as $\mathrm{N}$ (table 7).

\section{Timber Landing Road Near the Mashpee River in Mashpee}

The Timber Landing Road site borders the western edge of the Mashpee River (fig. 9), which flows south to Popponesset Bay on Nantucket Sound (fig. 1). Groundwater near the site generally flows eastward toward the Mashpee River and an extensive salt marsh that borders the river. Ditches and ponds from past cranberry production are still in the area. Development on the upgradient (western) side of the site consists of widely spaced houses and commercial areas. The distance to groundwater discharge areas in the bordering salt marsh from a potential 1,000-ft (305-m) PRB installation along the road would range from 100 to more than $500 \mathrm{ft}$ (31 to 152 m; fig. 9). The stretch of Timber Landing Road selected for investigation is a dirt track through conservation land. Consequently, the road is not used for traffic and there are no overhead or underground utilities that affected site access. The altitude change between Timber Landing Road and the river is about $15 \mathrm{ft}(5 \mathrm{~m})$.

The area of the Lower Mashpee subwatershed is 2,219 acres $\left(9 \mathrm{~km}^{2}\right)$. Land use in the subwatershed is more mixed than in the other subwatersheds in the study but is still dominated by residential development. Most of the houses and businesses in the subwatershed use septic systems for wastewater disposal, but 14 properties are connected to a municipal sewer system. Based on water use and nitrogenloading rates from the WatershedMVP application, the estimated load to the subwatershed from 608 properties on septic systems and other sources is $5,050 \mathrm{~kg} / \mathrm{yr}$ (table 7). The contributing area to the length of Timber Landing Road that could potentially contain a 1,000-ft (305-m) PRB was estimated to be approximately 5 percent of the total subwatershed area. The load estimate to the potential PRB at this site was found to be sensitive to the length of the potential PRB and shape of the associated contributing area. The WatershedMVP application indicated that the estimated nitrogen load to the PRB contributing area from 86 properties on septic systems and other sources is $430 \mathrm{~kg} / \mathrm{yr}$, or about 8 percent of the total load to the Lower Mashpee River from its subwatershed (table 7). Approximately 76 percent of the wastewater load to the PRB contributing area is derived from single-family residential development.

Seven water-table wells (TL-1 through TL-7) and one well cluster (TLZ) consisting of ten 1-ft $(0.3-\mathrm{m})$ well screens were installed for the ISI (fig. 9; table 5). Well screens in the cluster are set in the depth interval from 14 to $100 \mathrm{ft}$ (4 to $31 \mathrm{~m}$ ) below land surface. Upgradient wells were installed along Timber Landing Road at the northern and southern ends of the potential PRB location. The continuous core collected from well cluster TLZ showed that fine to coarse sand was present from land surface to $51.9 \mathrm{ft}(15.8 \mathrm{~m})$ below land surface, silty sand was present from 51.9 to $58.5 \mathrm{ft}$ (15.8 to $17.8 \mathrm{~m}$ ) below land surface, and fine to coarse sand was present from $58.5 \mathrm{ft}(17.8 \mathrm{~m})$ below land surface to the bottom of the core at $100 \mathrm{ft}(31 \mathrm{~m})$ below land surface (fig. 10).

Groundwater levels from the second sampling round in April 2016 indicated that the water table along Timber Landing Road was approximately $10 \mathrm{ft}(3 \mathrm{~m})$ below land surface or $2 \mathrm{ft}(0.6 \mathrm{~m})$ above sea level (fig. 9; table 5). The local configuration of the water table at this site is not well defined because of the linear arrangement of wells along Timber Landing Road; however, flow is generally toward the Mashpee River, as expected. The horizontal hydraulic gradient near wells TL-7 and TL-6, where there is relatively good definition of the water table, was 0.006 . The vertical gradient in the interval from 14 to $100 \mathrm{ft}$ (4 to $31 \mathrm{~m}$ ) below land surface in well cluster PCZ was 0.036 upward overall. However, vertical gradients were slightly downward to $70 \mathrm{ft}$ $(21 \mathrm{~m})$ below land surface, which spans the potential PRB treatment zone. Heads below $70 \mathrm{ft}(21 \mathrm{~m})$ below land surface were approximately $3 \mathrm{ft}(0.9 \mathrm{~m})$ higher than heads above this depth, suggesting that groundwater at depth may be under confined conditions. Using the median hydraulic conductivity of $220 \mathrm{ft} / \mathrm{d}(67 \mathrm{~m} / \mathrm{d})$ for the glacial stratified drift on Cape Cod (Masterson and Barlow, 1995), the specific discharge in this zone is $1.3 \mathrm{ft} / \mathrm{d}(0.4 \mathrm{~m} / \mathrm{d})$, assuming that the horizontal hydraulic gradient of 0.006 in shallow groundwater is representative of the entire treatment zone.

Data from the May 2016 sampling round were used to provide an overview of vertical and horizontal distributions of nitrate, dissolved oxygen, and dissolved iron at the site (table 5). Nitrate concentrations in samples from well cluster TLZ ranged from 0.030 (less than the quantitation limit but greater than 0) to $3.0 \mathrm{mg} / \mathrm{L}$ nitrate as N (fig. 10). Dissolved oxygen ranged from 0.39 to $7.2 \mathrm{mg} / \mathrm{L}$, and dissolved iron ranged from $<0.020$ to $0.41 \mathrm{mg} / \mathrm{L}$. Nitrate concentrations peak in the depth interval from 20 to $40 \mathrm{ft}$ (6 to $12 \mathrm{~m}$ ) below land surface and decrease to around $1 \mathrm{mg} / \mathrm{L}$ as $\mathrm{N}$ below this interval. Nitrate concentrations in samples from water-table wells, which represent spatial water-quality variability in shallow groundwater, were similar to concentrations in the upper interval of the well cluster, ranging from $<0.019$ to $2.2 \mathrm{mg} / \mathrm{L}$ nitrate as $\mathrm{N}$ (table 5). Dissolved oxygen concentrations in shallow groundwater ranged from 0.22 to $5.0 \mathrm{mg} / \mathrm{L}$. Because groundwater was aerobic in nearly all samples, conditions in shallow groundwater are not conducive for naturally occurring denitrification.

The 43-ft (13-m) sandy interval from the water table to about $60 \mathrm{ft}(18 \mathrm{~m})$ below land surface would be the potential PRB treatment zone; however, the zone could be deeper if the low nitrate concentrations below $60 \mathrm{ft}$ below land surface 


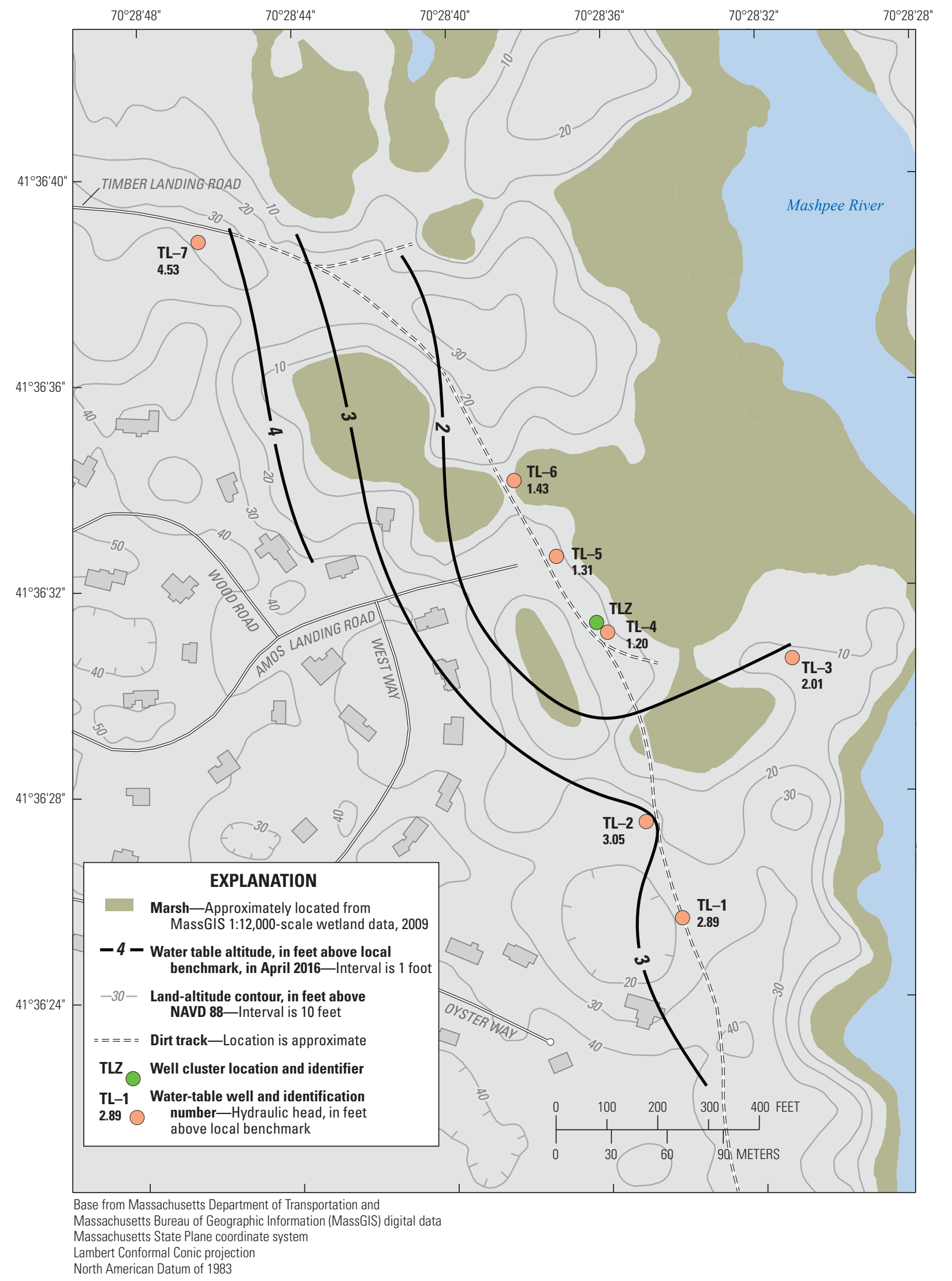

Figure 9. Topographic and hydrologic features, monitoring wells installed for the initial site investigation, and the altitude of the water table at the Timber Landing Road near the Mashpee River site in Mashpee, Massachusetts. 
$\boldsymbol{A}$

Specific conductance, in microsiemens per centimeter

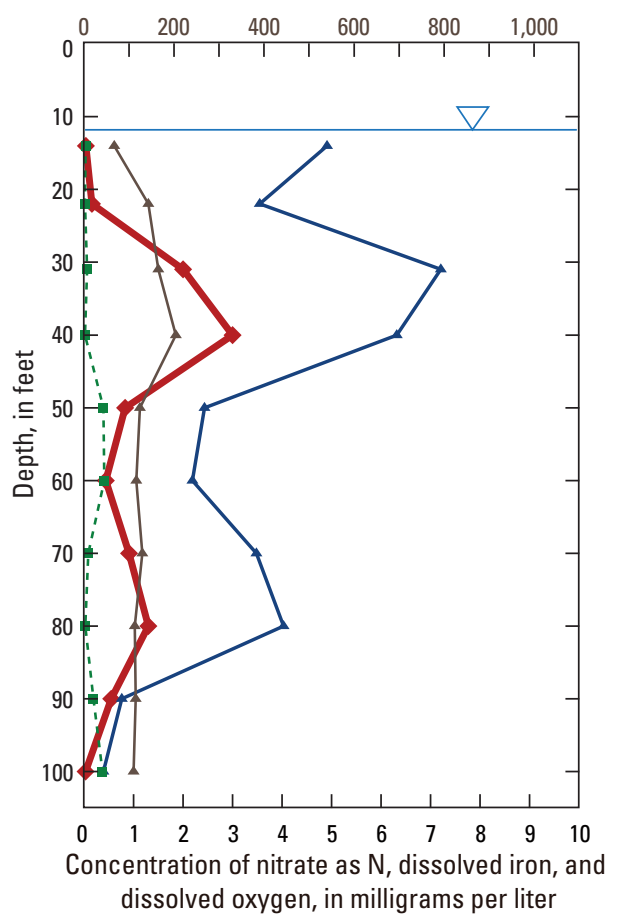

B

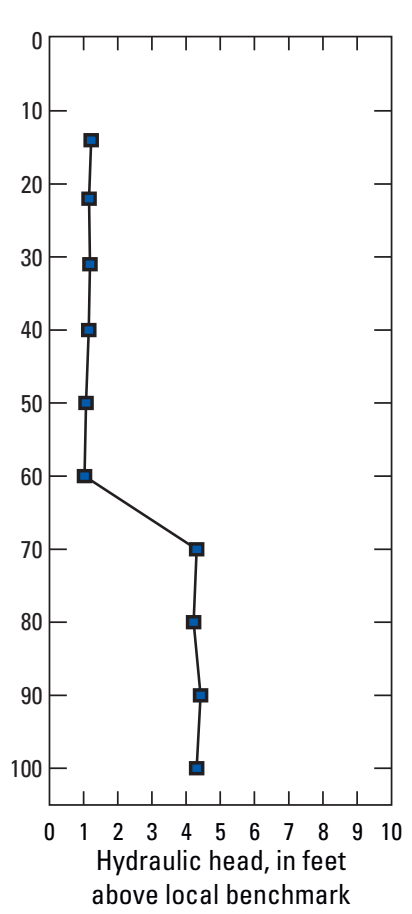

C

Generalized geologic log

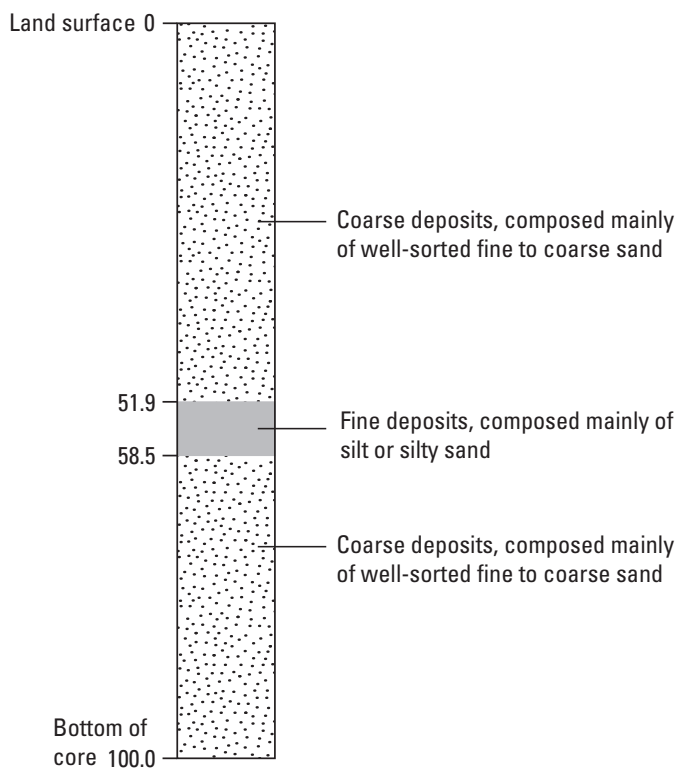

\section{EXPLANATION}

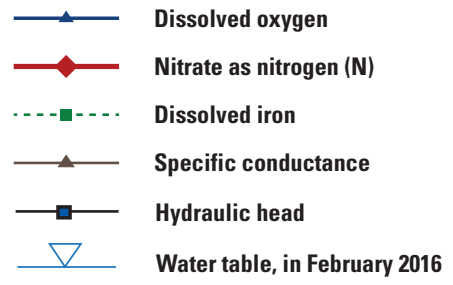

Figure 10. $A$, The vertical distributions of specific conductance, dissolved oxygen, dissolved iron, and nitrate as nitrogen in groundwater, $B$, the vertical distribution of hydraulic head, and $C$, the generalized stratigraphy at the Timber Landing Road near the Mashpee River site in Mashpee, Massachusetts. Water-quality data were collected in April 2016 for the initial site investigation. 
(fig. 10) also needed treatment. Based on available data, which include a median well-cluster nitrate concentration in the potential treatment zone of $0.83 \mathrm{mg} / \mathrm{L}$ nitrate as $\mathrm{N}$, a specific discharge of $1.3 \mathrm{ft} / \mathrm{d}(0.4 \mathrm{~m} / \mathrm{d})$, and a 43 -by-1,000-ft (13-by$305-\mathrm{m})$ PRB treatment-zone area perpendicular to groundwater flow, the nitrate load for the PRB would be $1.3 \mathrm{~kg} / \mathrm{d}$ nitrate as $\mathrm{N}$, or $470 \mathrm{~kg} / \mathrm{yr}$ nitrate as $\mathrm{N}$ (table 7).

\section{Vinland Drive Near Kelleys Bay in Dennis}

The Vinland Drive site was selected for an initial and a full site investigation. The preliminary regional assessment and the initial and full site investigations at the Vinland Drive site are described in this section.

\section{Preliminary Regional Assessment and Initial Site Investigation}

The Vinland Drive site borders the eastern edge of Kelleys Bay (fig. 11), an embayment of the Bass River (fig. 1). Groundwater near the site generally flows to the southwest toward Kelleys Bay. The site is bordered to the east by a residential area developed in the 1960s. Vinland Drive is on a bluff about $45 \mathrm{ft}(14 \mathrm{~m})$ above the bay. A PRB along Vinland Drive would be located approximately $200 \mathrm{ft}(61 \mathrm{~m})$ from the groundwater discharge area at the bay's shoreline. Drilling access was affected by underground (gas, water, and storm sewer) and overhead (electric, cable, and telephone) utilities.

The area of the Kelleys Bay subwatershed is 1,149 acres $\left(4.6 \mathrm{~km}^{2}\right)$. Land use in the subwatershed is dominated by residential development. All homes and businesses in the subwatershed use septic systems for wastewater disposal. Based on water use and nitrogen-loading rates in the WatershedMVP application, the estimated total load to the subwatershed from 814 properties and other sources is $5,230 \mathrm{~kg} / \mathrm{yr}$ (table 7). The contributing area to the length of Vinland Drive that could contain a $1,000-\mathrm{ft}(305-\mathrm{m})$ PRB was estimated to be approximately 350 acres $\left(1.4 \mathrm{~km}^{2}\right)$, or one-third of the total subwatershed area (fig. 2). The data from the WatershedMVP application indicated that the estimated nitrogen load to the PRB contributing area from 240 properties and other sources is $1,440 \mathrm{~kg} / \mathrm{yr}$, or about 28 percent of the total load to Kelleys -Bay from its subwatershed (table 7). Approximately 84 percent of the wastewater load to the PRB contributing area is derived from single-family residential development.

Six water-table wells (VL-1 through VL-6) and one well cluster (VLZ) consisting of six 1-ft (0.3-m) well screens were installed for the ISI (table 5; fig. 11). Well screens in the cluster are set in the depth interval from 44 to $66 \mathrm{ft}$ (13 to $20 \mathrm{~m}$ ) below land surface. The upgradient well was installed along Thorwald Drive approximately $400 \mathrm{ft}(122 \mathrm{~m})$ from the intersection with Vinland Drive. The continuous core collected from well-cluster VLZ showed the presence of fine to coarse sand from land surface to $48.5 \mathrm{ft}(14.8 \mathrm{~m})$ below land surface (also referred to as the upper sand unit), clay from 48.5 to
$51.5 \mathrm{ft}$ (14.8 to $15.7 \mathrm{~m}$ ) below land surface (also referred to as the upper clay unit), fine to coarse sand from 51.5 to $66.2 \mathrm{ft}$ (15.7 to $20.2 \mathrm{~m}$ ) below land surface (also referred to as the lower sand unit), and clay from $66.2 \mathrm{ft}(20.2 \mathrm{~m})$ below land surface to the bottom of the core at $80 \mathrm{ft}(24.4 \mathrm{~m})$ below land surface (fig. 12).

Groundwater levels from the second sampling round in May 2016 indicate that the water table along Vinland Drive is approximately $40 \mathrm{ft}(12 \mathrm{~m})$ below land surface, or $5 \mathrm{ft}$ (2 m) above sea level (fig. 11; table 5). The local configuration of the water table is not well defined because of the linear arrangement of wells along Vinland Drive, but available data indicate that flow is nearly perpendicular to the shoreline of Kelleys Bay. The horizontal hydraulic gradient between wells VL -3 and VL -6 was relatively steep (0.012), and the vertical gradient between the highest and lowest wells in well cluster VLZ-2 was 0.13 upward. However, vertical gradients within the more permeable sandy deposits were smaller, and there was a substantial difference in hydraulic head across the clay layer at $48 \mathrm{ft}(14.6 \mathrm{~m})$ below land surface. Heads in the lower sand unit below the clay layer were about $3 \mathrm{ft}(1 \mathrm{~m})$ higher than heads above the layer, suggesting that the lower sand unit (51.5 to $66.2 \mathrm{ft}$ [ 15.7 to $20.2 \mathrm{~m}$ ] below land surface) is under confined conditions. Using a median hydraulic conductivity of $220 \mathrm{ft} / \mathrm{d}(67 \mathrm{~m} / \mathrm{d})$ for the glacial stratified drift on Cape Cod (Masterson and Barlow, 1995), the specific discharge in this zone is $2.6 \mathrm{ft} / \mathrm{d}(0.8 \mathrm{~m} / \mathrm{d})$, assuming that the horizontal gradient of 0.012 in shallow groundwater is representative of the lower sand unit.

Data from the May 2016 sampling round were used to provide an overview of vertical and horizontal distributions of nitrate, dissolved oxygen, and dissolved iron at the site (table 5). Detailed descriptions of water-quality results are provided in Truslow and others (2016). Nitrate concentrations in samples from well cluster VLZ ranged from 2.5 to $4.3 \mathrm{mg} / \mathrm{L}$ nitrate as $\mathrm{N}$ in the depth interval from 40 to $66 \mathrm{ft}$ (12 to $20 \mathrm{~m}$ ) below land surface (fig. 12). These results indicate that the vertical variability in nitrate concentrations in the potential PRB treatment zone is relatively low. Dissolved oxygen ranged from 4.7 to $7.1 \mathrm{mg} / \mathrm{L}$, and dissolved iron remained below $0.90 \mathrm{mg} / \mathrm{L}$ in this vertical interval. Nitrate concentrations in samples from water-table wells, which indicate the spatial variability of water quality in shallow groundwater, were more variable than in the vertical well cluster, ranging from 0.41 to $7.4 \mathrm{mg} / \mathrm{L}$ nitrate as $\mathrm{N}$ (table 5). Dissolved oxygen concentrations in shallow groundwater ranged from 7.3 to $10.2 \mathrm{mg} / \mathrm{L}$. Groundwater was aerobic in all samples, indicating that conditions are not conducive for naturally occurring denitrification.

The upper (from the water table to $48.5 \mathrm{ft}[14.8 \mathrm{~m}]$ below land surface) and lower (from 51.5 to $66.2 \mathrm{ft}$ [15.7 to $20.2 \mathrm{~m}$ ] below land surface) sand units that straddle the upper clay layer (48.5 to $51.5 \mathrm{ft}$ [14.8 to $15.7 \mathrm{~m}$ ] below land surface) would compose the potential PRB treatment zone. Based on available data, which include a median well-cluster nitrate concentration in the potential treatment zone of $3.4 \mathrm{mg} / \mathrm{L}$ 


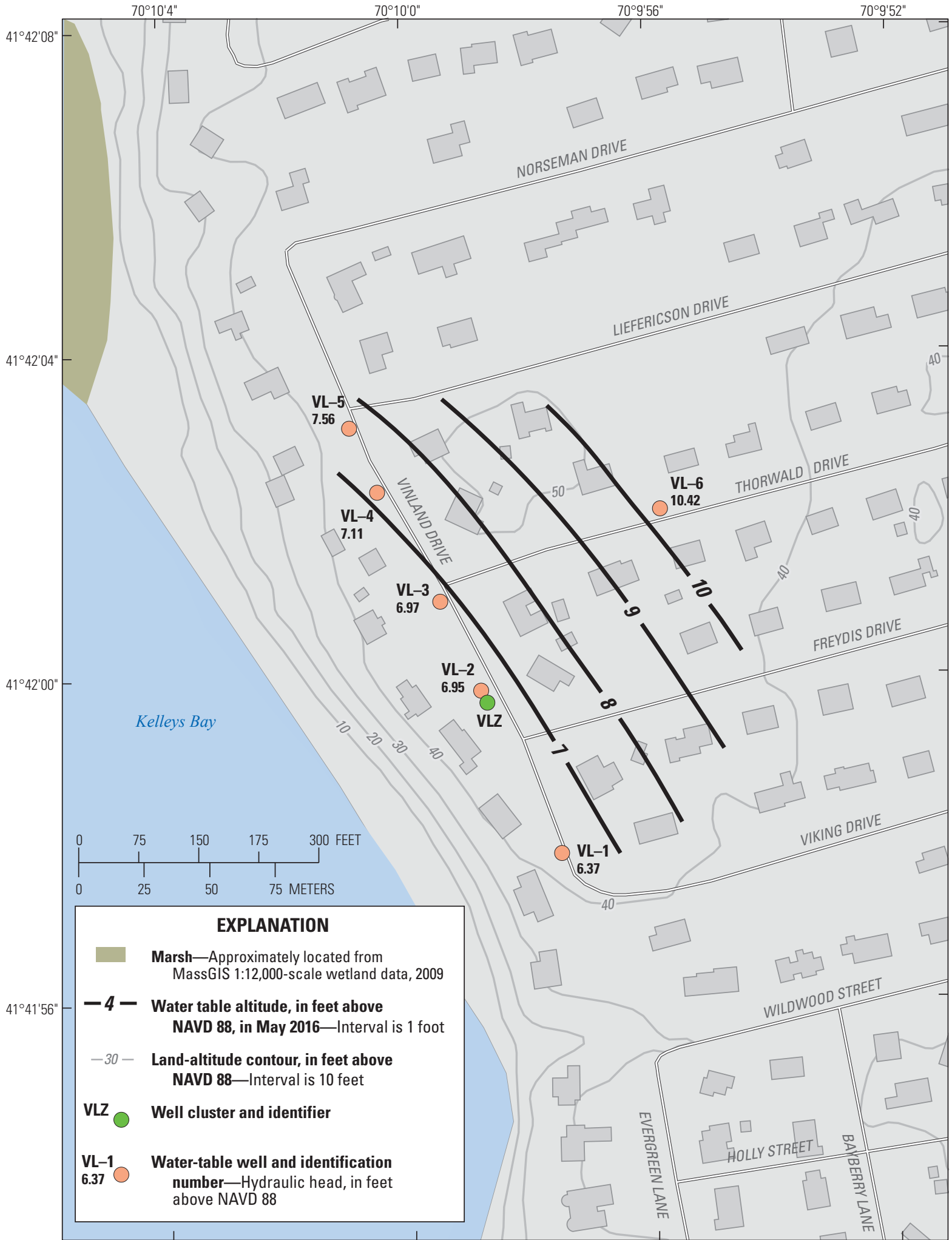

Base from Massachusetts Department of Transportation and

Massachusetts Bureau of Geographic Information (MassGIS) digital data

Massachusetts State Plane coordinate system

Lambert Conformal Conic projection

North American Datum of 1983

Figure 11. Topographic and hydrologic features, monitoring wells installed for the initial site investigation, and the altitude of the water table at the Vinland Drive near Kelleys Bay site in Dennis, Massachusetts. 
$\boldsymbol{A}$

Specific conductance, in microsiemens per centimeter

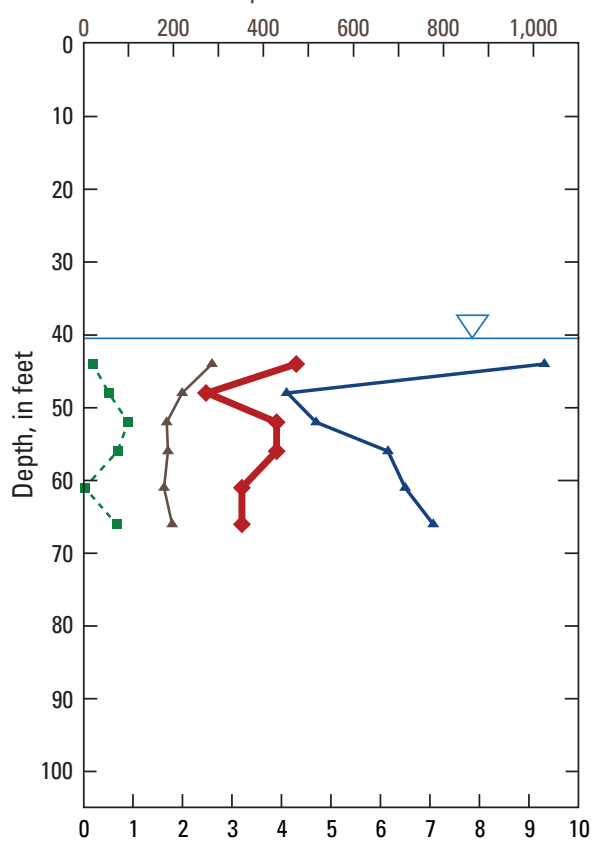

Concentration of nitrate as $\mathrm{N}$, dissolved iron, and dissolved oxygen, in milligrams per liter
B C

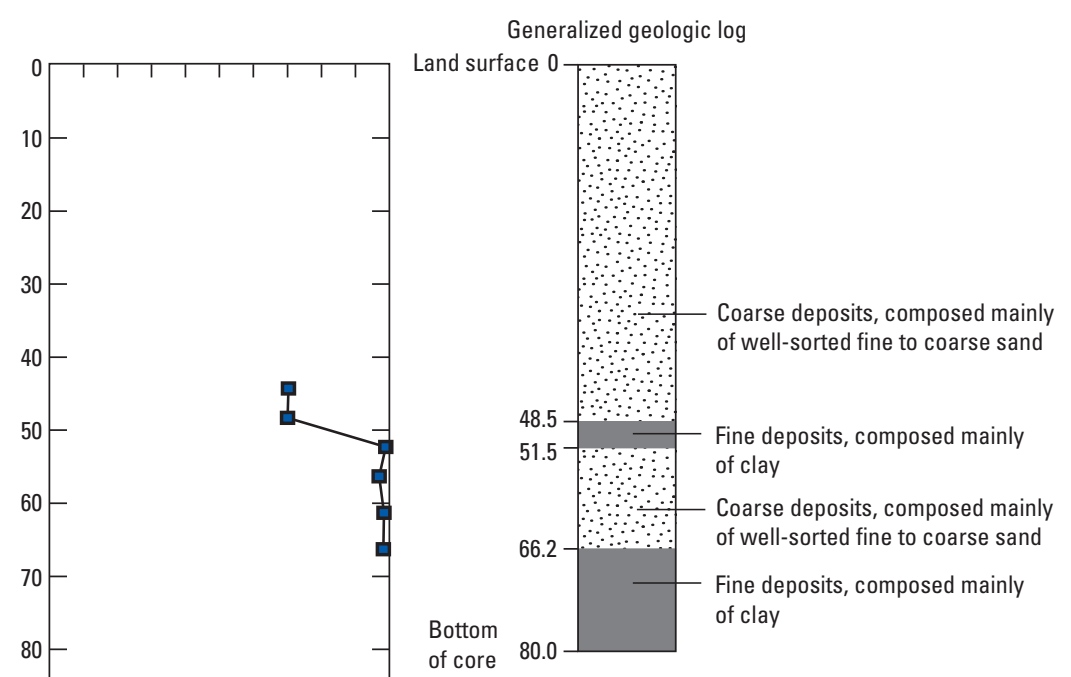

EXPLANATION

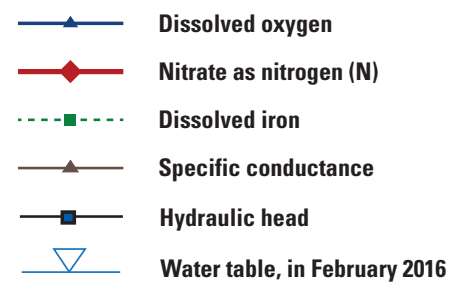

Figure 12. $A$, The vertical distributions of specific conductance, dissolved oxygen, dissolved iron, and nitrate as nitrogen in groundwater, $B$, the vertical distribution of hydraulic head, and $C$, the generalized stratigraphy at the Vinland Drive near Kelleys Bay site in Dennis, Massachusetts. Water-quality data were collected in May 2016 for the initial site investigation. 
nitrate as $\mathrm{N}$ in the upper sand unit and $3.6 \mathrm{mg} / \mathrm{L}$ nitrate as $\mathrm{N}$ in the lower sand unit, a specific discharge of $2.6 \mathrm{ft} / \mathrm{d}$ $(0.8 \mathrm{~m} / \mathrm{d})$, and a 23-by-1,000-ft (7-by-305-m) PRB treatmentzone area perpendicular to groundwater flow, the calculated nitrate load to the PRB would be $6.0 \mathrm{~kg} / \mathrm{d}$ nitrate as $\mathrm{N}$, or $2,200 \mathrm{~kg} / \mathrm{yr}$ nitrate as $\mathrm{N}$ (table 7); the saturated thickness of the upper unit and associated nitrate load would vary with watertable fluctuations.

\section{Full Site Investigation}

The FSI at the Vinland Drive site consisted of additional well installation and hydrologic and water-quality data collection (Truslow and others, 2017). The field program consisted of installation of three water-table wells in new locations (VL-7, VL-8, and VL-9), three well clusters at existing locations (VLZ-4, VLZ-6, and VLZ-7), each consisting of four wells with $1-\mathrm{ft}(0.3-\mathrm{m})$ screens, and four wells in the lower sand unit paired with shallow wells (VL-1d, VL-2d, VL-8d, and VL-9d; fig. 13; table 6). Hydrologic data collection consisted of continuous cores at all new well locations, three rounds of manual water-level measurements, and continuous water-level measurements in two water-table wells in the upper sand unit (VL-5 and VL-6) and four wells in the confined lower sand unit (VL-1d, VL-2d, VL-8d, and VL-9d) to evaluate tidal influence on water levels. In addition, grain-size sieve analyses were run on 19 aquifer-sediment samples and slug tests were conducted at 11 wells. Waterquality data collection consisted of one round of groundwater samples from most of the wells, including from shallow wells WP-1, WP-2, and WP-3 near the shoreline of Kelleys Bay and from the surface-water site SW-1 in Kelleys Bay (fig. 13). All groundwater and surface-water samples were analyzed for ISI constituents (table 4); selected groundwater samples also were analyzed for stable nitrogen isotopes (Truslow and others, 2017).

The summary of the FSI results presented in this report focuses on the changes in the understanding of site conditions compared with the ISI baseline characterization. Improvements in the characterization of the hydrogeologic framework (mainly spatial extent of clay layers), hydrology (hydraulic gradients, flow directions, and flow rates), and water quality are discussed in the following section. Truslow and others (2017) provide a detailed description of the FSI data collection and results at this site.

The collection of continuous cores at the new well locations showed that the layering observed at VLZ during the ISI is representative of the area along and upgradient from Vinland Drive where the potential PRB could be located (Truslow and others, 2017, figs. 2 and 3). The upper clay unit is continuous across the site, varying in thickness from 3 to $10 \mathrm{ft}(0.9$ to $3 \mathrm{~m})$. Because the clay unit locally is continuous, the upper and lower sand units are treated as separate aquifers; this interpretation is supported by the additional hydrologic data discussed below. In all locations, the upper sand unit extends to land surface and the lower sand unit, which varies in thickness from 9 to $15 \mathrm{ft}$ (2.7 to $4.6 \mathrm{~m})$, is bounded by a lower clay unit of undetermined thickness. The altitudes and thicknesses of these units vary across the site (Truslow and others, 2017) but are relatively uniform in the context of PRB installation and monitoring. The thickness of the lower clay unit and occurrence of elevated nitrate concentrations at depth remain unknowns at the site. In this instance, the characterization of the hydrogeologic framework from the ISI data would have been inadequate. Because substantial heterogeneities in subsurface materials were present, which could affect the design and effectiveness of a PRB, additional characterization to determine the lateral extent of these layers was required.

The results from the collection of additional hydrologic data for the FSI indicated that the preliminary interpretation of hydrologic conditions at the site from the ISI data was reasonable. For example, although the water table declined by about $1 \mathrm{ft}(0.3 \mathrm{~m})$ between May 2016 and May 2017, flow directions and horizontal gradients were similar for these two rounds of measurements (figs. 11 and 13A; tables 5 and 6), indicating that the water-table configuration developed from ISI data with fewer upgradient measurements was reasonably representative of the upper sand unit. However, additional data were required to better understand the hydrology of the lower sand unit and refine the calculations of flow directions and rates in both sand units.

Hydraulic-head data collected in May 2017 for the FSI indicated that the flow direction in the lower sand unit was similar to the flow direction in the upper sand unit, generally to the southwest toward Kelleys Bay (fig. 13; table 6). However, the horizontal hydraulic gradient in the lower sand unit was substantially lower than in the upper sand unit. In May 2017, the horizontal hydraulic gradient was about 0.010 in the upper sand unit and 0.003 in the lower sand unit. The FSI data also confirmed the preliminary ISI interpretation that the lower sand unit is under confined conditions. This confirmation is based on the presence of the upper clay unit across the site, the altitudes of the heads in the lower sand unit (in May 2017, the potentiometric surface was above the upper clay unit in the lower sand unit wells), and the tidal fluctuations of groundwater levels in the lower sand unit (Truslow and others, 2017). Observed tidal fluctuations of groundwater levels of about $0.15 \mathrm{ft}(0.5 \mathrm{~m})$ in the lower sand unit would have minor effects on the magnitude of hydraulic gradients and flow directions but would not appreciably affect the design and effectiveness of a PRB.

Hydraulic conductivity measurements indicated that the lower sand unit is slightly more permeable than the upper sand unit (tables 8 and 9). Truslow and others (2017) also noted that hydraulic conductivity is spatially variable within these units, with the highest values near wells VL-2 and VL-6, which are near the center of the potential PRB. Nonetheless, the observed spatial within-unit variability in hydraulic conductivity was not explicitly represented in the FSI load calculations made at this site. Rather, a single, representative value was computed for each sand unit for use in equation 1. Although this simplified approach may underestimate 


\section{A. Water table in upper sand unit}

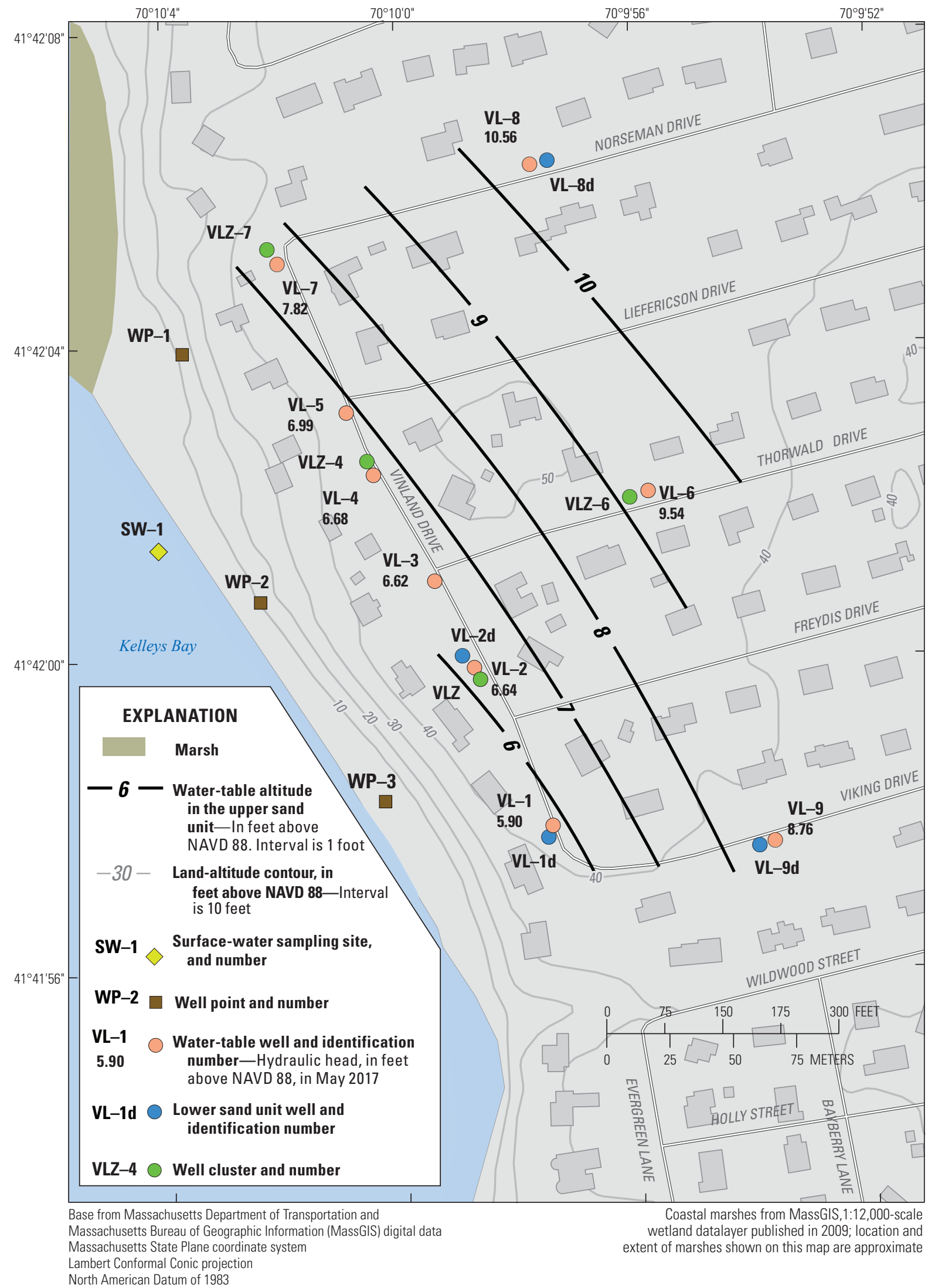

Figure 13. Topographic and hydrologic features, monitoring wells, drive points, surface-water sampling sites installed for the initial and full site investigations, and the altitude of $A$, the water table in the upper sand unit, and $B$, the potentiometric surface in the lower sand unit at the Vinland Drive near Kelleys Bay site in Dennis, Massachusetts. 


\section{B. Potentiometric surface in lower sand unit}

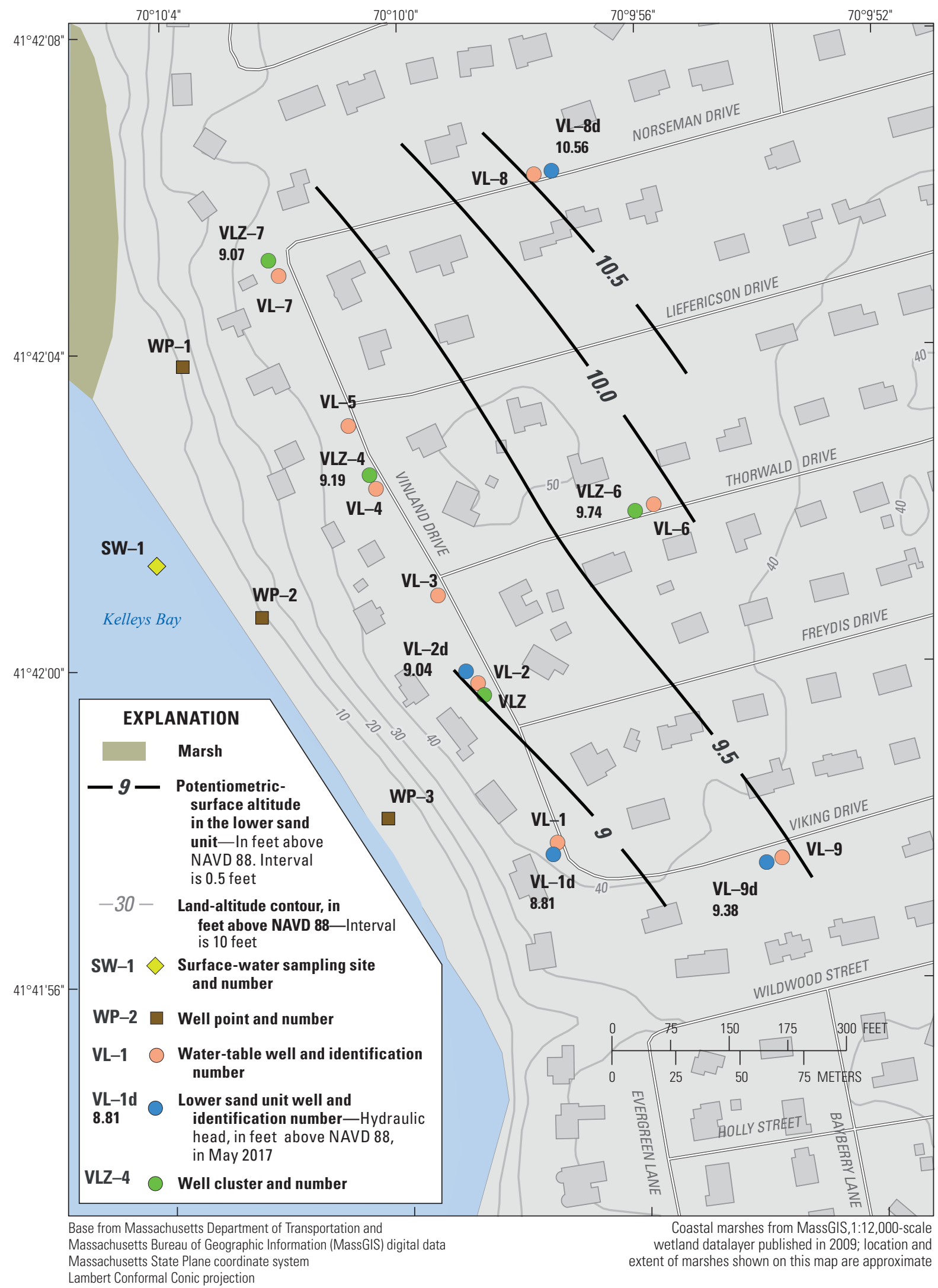

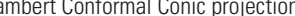

Figure 13. Topographic and hydrologic features, monitoring wells, drive points, surface-water sampling sites installed for the initial and full site investigations, and the altitude of $A$, the water table in the upper sand unit, and $B$, the potentiometric surface in the lower sand unit at the Vinland Drive near Kelleys Bay site in Dennis, Massachusetts.-Continued 
Table 8. Hydraulic conductivity of the glacial stratified drift determined from grain-size analysis at the Vinland Drive near Kelleys Bay site in Dennis, Massachusetts.

[Data are from Truslow and others (2017). Hydraulic conductivity is the average of the Kozeny-Carman and Alyamani-Sen solutions (Truslow and others, 2017). Well locations shown in figure 13. ft, foot; ft/d, foot per day; NA, not applicable]

\begin{tabular}{lcc}
\hline $\begin{array}{c}\text { Well } \\
\text { location }\end{array}$ & $\begin{array}{c}\text { Sample collection interval, } \\
\text { in ft below land surface }\end{array}$ & $\begin{array}{c}\text { Hydraulic conductivity, } \\
\text { in ft/d }\end{array}$ \\
\hline \multicolumn{3}{c}{ Upper sand unit } \\
\hline VL-2 & $45.5-46.3$ & 620 \\
VL-2 & $46.3-47.0$ & 35.5 \\
VL-4 & $41.0-45.0$ & 7.2 \\
VL-6 & $40.0-42.8$ & 83.6 \\
VLZ-6 & $45.0-46.7$ & 290 \\
VLZ-7 & $40.0-42.8$ & 6.0 \\
VL-9 & $30.0-37.6$ & 68.0 \\
Mean & NA & 159 \\
Median & NA & 68.0 \\
\hline & Lower sand unit \\
\hline VL-2 & $51.2-52.8$ & 125 \\
VL-2 & $55.0-56.2$ & 181 \\
VL-2 & $56.2-57.5$ & 144 \\
VL-2 & $60.0-62.0$ & 403 \\
VLZ-4 & $50.4-52.5$ & 165 \\
VLZ-4 & $60.0-63.4$ & 89.4 \\
VLZ-6 & $55.6-57.4$ & 196 \\
VLZ-6 & $60.0-62.5$ & 133 \\
VLZ-6 & $65.0-65.6$ & 575 \\
VLZ-7 & $52.1-53.4$ & 69.3 \\
VL-7 & $55.0-58.2$ & 54.9 \\
VL-7 & $60.0-61.3$ & 478 \\
Mean & NA & 139 \\
Median & NA &
\end{tabular}

nitrate loads if a substantial fraction of groundwater flows preferentially through high-hydraulic-conductivity zones, the densities of the FSI hydraulic-conductivity and nitrate data were insufficient for development of a more detailed approach that accounts for spatial variability along the PRB treatment zone. Accordingly, all hydraulic conductivity values in the upper and lower sand units were pooled to compute a separate median for each unit (tables 8 and 9). In the upper sand unit, the median hydraulic conductivity is $68 \mathrm{ft} / \mathrm{d}(21 \mathrm{~m} / \mathrm{d})$ from grain-size analysis (ranging from 6.0 to $620 \mathrm{ft} / \mathrm{d}[1.8$ to $189 \mathrm{~m} / \mathrm{d}$ ], with the number of samples $[n]=7$; table 8 ) and $98 \mathrm{ft} / \mathrm{d}(30 \mathrm{~m} / \mathrm{d})$ from slug tests $(32$ to $370 \mathrm{ft} / \mathrm{d}$ [10 to $113 \mathrm{~m} / \mathrm{d}$ ], $n=6$; table 9). In the lower sand unit, the median hydraulic
Table 9. Hydraulic conductivity of the glacial stratified drift determined from slug tests at the Vinland Drive near Kelleys Bay site in Dennis, Massachusetts.

[Data are from Truslow and others (2017). Well VL-2d recovered too quickly to calculate hydraulic conductivity; estimated value of $370 \mathrm{ft} / \mathrm{d}$ used to determine summary statistics for the lower sand unit. Well locations shown in figure 13. ft, foot; ft/d, foot per day; NA, not applicable; >, greater than]

\begin{tabular}{lcc}
\hline Well location & $\begin{array}{c}\text { Well-screen interval, } \\
\text { in ft below land surface }\end{array}$ & $\begin{array}{c}\text { Hydraulic conductivity, } \\
\text { in ft/d }\end{array}$ \\
\hline UL-2 & Upper sand \\
VL-3 & $41-46$ & 110 \\
VL-4 & $39-44$ & 140 \\
VL-6 & $38-43$ & 52.0 \\
VLZ-6a & $35-40$ & 32.0 \\
VLZ-6b & $40-41$ & 86.0 \\
Mean & $46-47$ & 370 \\
Median & NA & 132 \\
\hline & NA & 98.0 \\
\hline VL-2d & Lower sand & \\
VLZ-4b & $52-62$ & 23.0 \\
VLZ-4c & $51-52$ & 110 \\
VLZ-6c & $57-58$ & 120 \\
VLZ-6d & $57-58$ & 300 \\
Mean & $63-64$ & 185 \\
Median & NA & 120 \\
\hline
\end{tabular}

conductivity is $139 \mathrm{ft} / \mathrm{d}(42 \mathrm{~m} / \mathrm{d})$ from grain-size analysis ( 4.5 to $575 \mathrm{ft} / \mathrm{d}$ [1.4 to $175 \mathrm{~m} / \mathrm{d}$ ], $n=12$; table 8 ) and $120 \mathrm{ft} / \mathrm{d}$ $(36 \mathrm{~m} / \mathrm{d}$ ) from slug tests (23 to greater than [>] $370 \mathrm{ft} / \mathrm{d}[7$ to $>133 \mathrm{~m} / \mathrm{d}], n=5$; table 9). Despite differences in scale (that is, the aquifer volume tested), location, and method of analysis, results from the two methods agreed relatively well. These hydraulic conductivity measurements may indicate that the $220-\mathrm{ft} / \mathrm{d}(67 \mathrm{~m} / \mathrm{d})$ value used for the ISI load calculation was an overestimate of the hydraulic conductivity of the transmissive layers at the Vinland Drive site.

The additional water-quality data collected for the FSI generally showed that the more limited ISI dataset was representative of water-quality conditions at the site (tables 5 and 6). Overall, sampling results for December 2016 through January 2017 indicated that groundwater in the upper and lower sand units is aerobic and contains nitrate in the range of 1 to $8 \mathrm{mg} / \mathrm{L}$ nitrate as $\mathrm{N}$. Pooling results from all wells, nitrate concentrations in shallow groundwater (upper sand unit) ranged from 1.7 to $8.1 \mathrm{mg} / \mathrm{L}$ nitrate as $\mathrm{N}$, with a median of $3.7 \mathrm{mg} / \mathrm{L}$ nitrate as $\mathrm{N}(n=14)$. Similarly, nitrate concentrations in the lower sand unit ranged from 2.1 to $5.0 \mathrm{mg} / \mathrm{L}$ nitrate as $\mathrm{N}$, with a median of $3.6 \mathrm{mg} / \mathrm{L}$ nitrate as $\mathrm{N}(n=12)$. Water quality along the potential PRB treatment zone was 
better characterized compared with the ISI by the addition of the three new well clusters (figs. 13 and 14; table 6). Vertical profiles were similar across the treatment zone. Median nitrate concentrations along the potential treatment zone were $3.6 \mathrm{mg} / \mathrm{L}$ nitrate as $\mathrm{N}(n=9)$ in the upper sand unit and $3.6 \mathrm{mg} / \mathrm{L}$ nitrate as $\mathrm{N}(n=10)$ in the lower sand unit, which are similar to the medians based on all the wells at the site. For calculating the nitrate load to the PRB treatment zone, the medians based on the larger datasets were used.

Based on the additional site-characterization data collected for the FSI, the calculated nitrate load for the potential PRB would be $1.5 \mathrm{~kg} / \mathrm{d}$ nitrate as $\mathrm{N}$, or $550 \mathrm{~kg} / \mathrm{yr}$ nitrate as $\mathrm{N}$, which is $1,650 \mathrm{~kg} / \mathrm{yr}$ nitrate as $\mathrm{N}$ less than the calculated load of 2,200 kg/yr nitrate as $\mathrm{N}$ calculated with the ISI data (table 7). Although the median FSI nitrate concentrations of $3.6 \mathrm{mg} / \mathrm{L}$ nitrate as $\mathrm{N}$ in the upper sand unit and $3.7 \mathrm{mg} / \mathrm{L}$ nitrate as $\mathrm{N}$ in the lower sand unit were similar to the concentrations used for the ISI calculation $(3.4$ and $3.6 \mathrm{mg} / \mathrm{L}$ nitrate as $\mathrm{N}$, respectively), the specific discharges in both sand units were substantially lower than the value used for the ISI calculation, primarily because the medians of the measured hydraulic conductivity values were substantially lower than the ISI-estimated value of $220 \mathrm{ft} / \mathrm{d}(67 \mathrm{~m} / \mathrm{d})$. Also, the measured horizontal hydraulic gradient in the lower sand unit was lower than the gradient in the upper sand unit by a factor of nearly 10 (in the ISI, the water-table gradient was applied to both units because of a lack of data in the lower unit). The dimensions of the treatment zones in the upper and lower sand units did not change appreciably compared with the dimensions based on the ISI data. The disparity in calculated loads between the ISI and FSI shows the importance of site-specific water-quality and hydrologic data, particularly at a site with relatively complex hydrogeology. In this instance, most of the disparity can be attributed to differences between estimated and measured hydraulic conductivity. The updated calculated nitrogen load $(550 \mathrm{~kg} / \mathrm{yr})$ to the potential PRB treatment zone is 38 percent of the estimated load to the groundwater-contributing area of the proposed PRB (1,440 kg/yr; table 7).

\section{A. VLZ}

B. VLZ-4

C. VLZ-6

D. VLZ-7

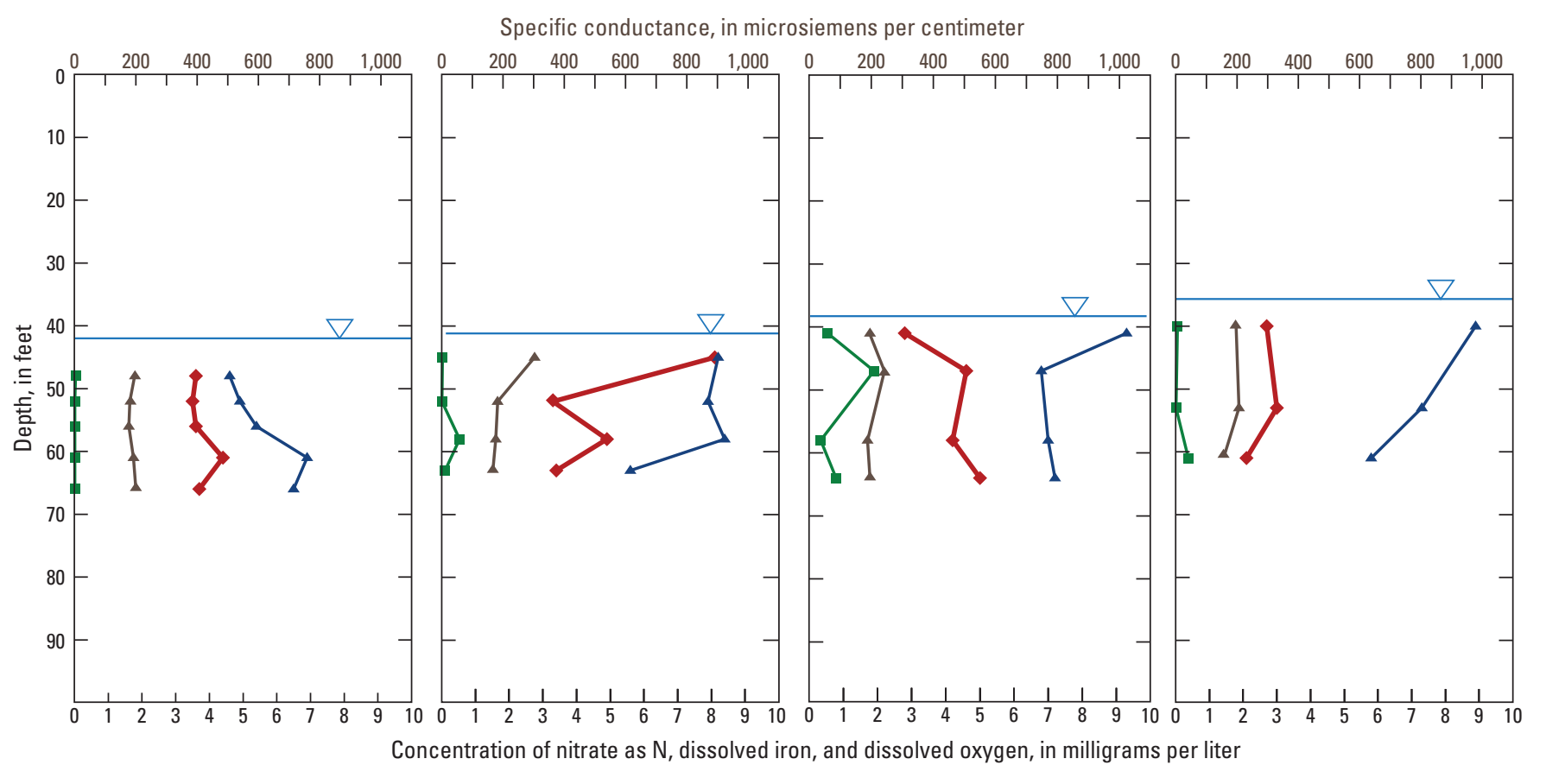

EXPLANATION

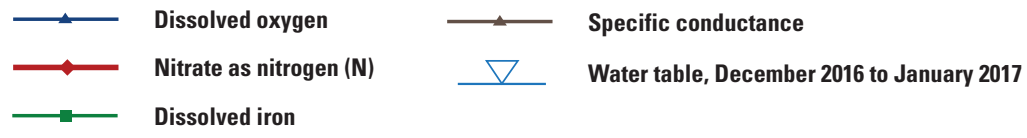

Figure 14. The vertical distributions of specific conductance, dissolved oxygen, dissolved iron, and nitrate as nitrogen in groundwater at well clusters $A, \mathrm{VLZ}, B, \mathrm{VLZ}-4, C, \mathrm{VLZ}-6$, and $D, \mathrm{VLZ}-7$ at the Vinland Drive near Kelleys Bay site in Dennis, Massachusetts. Data were collected from December 2016 through January 2017 for the full site investigation. 


\section{Discussion}

The use of PRBs on Cape Cod for passive treatment of nitrogen in groundwater represents a novel application of PRB technology. Since the technology was developed in the 1990s, most PRBs have been used to remediate discrete, individual contaminant plumes (Interstate Technology and Regulatory Council, 2011). In these conventional applications, the placement and design of a PRB primarily are determined by the location and composition of the individual plume undergoing remediation. Typically, contaminant plumes and local subsurface conditions are well characterized before PRBs are designed and installed. In contrast, on Cape Cod, individual plumes are not present. Rather, discharge from thousands of individual septic systems has produced widespread nonpointsource nitrogen contamination that contributes to the eutrophication of streams, lakes, and coastal water bodies. Under these circumstances, nearly the entire coastline potentially requires treatment to reduce nitrogen loads, and there are many possible locations and design options for PRBs. Because contamination is widespread, it may appear that PRB installation can proceed with relatively little consideration given to site selection and characterization. However, in contrast to the conventional point-source application where previous sitecharacterization work would have been done, adequate characterization of site conditions is lacking in most of the potential PRB locations on Cape Cod. Consequently, site assessment will be needed in nearly all locations to determine if a prospective site is well suited for PRB installation and, if so, to collect the information needed for design and installation.

The phased site-assessment approach developed for this study provides a template for town officials and other stakeholders to follow when considering PRBs for passive treatment of nitrogen in groundwater on Cape Cod and elsewhere. The phased approach proved to be successful for screening sites and characterizing the geologic, hydrologic, and waterquality conditions at the sites selected for onsite investigations. Overall, the approach provided the information needed to determine site suitability and install a PRB. The application of the approach to the Cape Cod sites also provided insight into how well the expectations of the site-assessment approach were met and where improvements to the process could be made.

The preliminary regional assessment provided important screening-level information that was used to identify potentially viable PRB-installation locations. However, this study indicated that regional assessment alone was not enough to evaluate site viability primarily because it provided no information on actual subsurface conditions. Understanding site lithology is important because heterogeneity produces complex vertical and horizontal groundwater flow patterns that may adversely affect PRB performance. All five sites selected for ISIs were determined to be potentially viable locations based on the regional assessment, but core collection indicated that at least one site (Herring Brook Way near Kescayo Gansett [Lonnies] Pond in Orleans) likely was not well suited for a
PRB because of the presence of interlayered clay and finegrained sediments in the PRB treatment zone, which could not be determined from the preliminary regional assessment alone. One possible improvement to the regional assessment would be to locate and review existing subsurface information from previous hydrogeologic investigations in the area, if available, to improve the site-screening process. However, even if hydrogeologic information were available from previous investigations, additional onsite data would still be required to verify local hydrologic and water-quality conditions and determine treatment-zone dimensions. The preliminary regional assessment was more successful in estimating the depth to groundwater, the presence of nitrate at concentrations high enough to support PRB installation (based on upgradient land use), and, to a lesser extent, the orientation of the PRB perpendicular to local groundwater flow directions.

Subsurface geologic conditions were found to be variable among the five sites investigated in this study. The sites in Barnstable, Falmouth, and Mashpee contained mostly fine to coarse sands to depths of 80 to $100 \mathrm{ft}$ ( 24 to $31 \mathrm{~m}$ ) below land surface. The sites in Dennis and Orleans were more heterogeneous, with interlayered fine- and coarse-grained deposits (Herring Brook Way site) or a laterally extensive clay layer that separated the PRB treatment zone into two discrete aquifers (Vinland Drive site). The single continuous core collected during the ISI was adequate for an initial assessment of subsurface conditions, but additional cores typically will be required for full site characterization and PRB design. The total number of cores will be determined by the amount of subsurface heterogeneity and the dimensions (length and depth) of the PRB.

The hydrologic data collection specified for the ISIs (table 3) generally was adequate for developing a preliminary understanding of groundwater flow rates and directions. The exception was the original specification for three water-table wells, which was found to be insufficient for determining local groundwater flow directions. As a result, five to seven wells were installed at each site during the initial investigations, which should be considered the minimum number of wells for determination of groundwater flow directions at Cape Cod sites where site conditions are characterized for PRBs of approximately 1,000 ft (305 m) in length. Groundwater flow directions were all toward adjacent surface-water bodies, as expected, but the configuration of the shoreline, occurrence of coastal wetlands, and presence of subsurface heterogeneities had substantial effects on local flow directions. Locating wells upgradient from the PRB location to form an approximate grid pattern also is important for developing water-table maps that adequately represent the local groundwater flow system. The configuration of five to seven wells was adequate at these sites for estimating the horizontal hydraulic gradient in shallow groundwater. At the sites with relatively homogeneous aquifer sediments (for example, the sites in Barnstable, Falmouth, and Mashpee), the shallow gradients were more likely to be representative of the entire treatment interval and, consequently, could be used for PRB design and performance monitoring. 
However, at the more complex sites (for example, the Vinland Drive site), vertical gradients are more important, and hydraulic-head data below the water table may be needed to better characterize flow rates and directions to the entire vertical extent of the PRB treatment zone. For example, at the Vinland Drive site, strong upward gradients indicated the potential for flow across the clay layer between the lower and upper sand units. A phased site investigation would allow such data gaps to be addressed.

The ISI groundwater sampling schedule (table 3) was sufficient for developing a preliminary understanding of waterquality conditions in groundwater at all the Cape Cod sites. Of the constituents listed in table 3 , nitrate and redox-sensitive constituents such as dissolved oxygen and iron (tables 5 and 6 ) are likely to be the most important for site assessment. Nitrate concentrations ranged from not detected to about $8 \mathrm{mg} / \mathrm{L}$ nitrate as $\mathrm{N}$, with median concentrations of about $2 \mathrm{mg} / \mathrm{L}$ nitrate as $\mathrm{N}$ in zones where nitrate concentrations were above background levels (that is, the potential treatment zones). These relatively low nitrate levels were sufficient to produce annual loads of hundreds to thousands of kilograms of nitrate as $\mathrm{N}$.

Samples from water-table wells provided information about the spatial distribution of nitrate in shallow groundwater, but comparisons of results from the water-table wells and the single well cluster indicated that shallow groundwater quality typically was not representative of deeper groundwater quality in the treatment zone. Consequently, vertical water-quality profiles were necessary to determine the depth (thickness) of the potential treatment zones and characterize water quality within those zones. The ISIs showed that a single well cluster was adequate for an initial assessment of water-quality conditions with depth, particularly to determine whether nitrate concentrations were high enough to potentially support PRB installation. Additional vertical concentration profiles would be required along the planned length of the PRB to make a final determination of the depth of the treatment zone. Based on the data collected in this study, maximum treatment-zone depths at the five Cape Cod sites were determined to be in the range of 60 to $80 \mathrm{ft}$ (18 to $24 \mathrm{~m}$ ) below land surface. The total number of vertical profiles required for a more complete assessment of water-quality conditions would be determined by the observed variability in water-quality conditions and the dimensions of the PRB. As an example, the FSI at the Dennis site showed that three vertical concentration profiles over about a lateral distance of $1,000 \mathrm{ft}(305 \mathrm{~m})$ were adequate for characterizing water quality along the proposed length of the PRB (fig. 14).

The characterization of water-quality conditions may be improved by greater reliance on water-quality profiling (sampling without well installation) during the site-investigation phases. This approach should allow for more efficient characterization of the spatial distribution of nitrate and other constituents because profiling generates a relatively large number of samples that can be analyzed and interpreted in near-real time. These data then could be used to install permanent wells or multilevel sampling devices in selected locations for long-term monitoring. In areas where the water table is within suction lift $(<25 \mathrm{ft}[7.6 \mathrm{~m}]$ below land surface), use of multilevel sampling devices (for example, LeBlanc and others, 1991), which are more compact than conventional well clusters, could provide detailed vertical water-quality profiles and, consequently, may be preferable in selected locations. However, in areas where the water table is below suction lift, conventional wells are required. In general, locations with deep water tables will be more difficult to characterize and monitor because of constraints on sample-collection methods.

Information on nitrogen loading is important for evaluating PRB performance and determining load reductions to the receiving water body for regulatory compliance. In this study, loads to potential PRB treatment zones were estimated with the WatershedMVP application and calculated with data collected during the site investigations by use of Darcy's law (table 7) to obtain insight into data needs and comparability of values from the different methods. The loads estimated with the WatershedMVP application assumed that the nitrogen loads to the PRB treatment zone were equal to the nitrogen inputs to an estimated groundwater-contributing area to the PRB ("Site-Assessment Approach" section of this report). Thus, loads to potential PRBs were estimated from land-use patterns, assumed wastewater discharge rates that are constant over time, and assumed conservative transport in groundwater. The WatershedMVP application also estimates nitrogen inputs to the entire subwatershed, which allows for a determination of the percentage of the total nitrogen load to the receiving water body from the subwatershed that is potentially treated by a PRB of a given length (table 7). WatershedMVP-based percentages for the sites investigated in this study range from 8 percent at the Timber Landing Road site to 49 percent at the Herring Brook Way site for potential PRBs of about $1,000 \mathrm{ft}$ $(305 \mathrm{~m})$ in length. The differences are largely related to the shape and size of the subwatershed. Because the subwatershed for Kescayo Gansett Pond is relatively small and has a rectangular shape (Cape Cod Commission, 2018), a single PRB along the pond shoreline can potentially treat a large fraction of the total nitrogen load to the pond. In contrast, the lower Mashpee subwatershed straddles both sides of the Mashpee River, and the distances to the upgradient watershed boundaries are relatively small (Cape Cod Commission, 2018); consequently, the contributing area to a potential PRB and associated load reductions are small in comparison with the contributing area and load of the subwatershed. A comparison of expected PRB load reductions to the total subwatershed loads in the context of required load reductions to the receiving water body may be a useful addition to the preliminary regional assessment by informing decisions on the locations and dimensions of PRBs; this comparison was beyond the scope of this study.

Although the ISIs provided the hydrologic, lithologic, and water-quality data needed to calculate loads, calculated values were based on simplifying assumptions and sparse data. Data from a single well cluster were used to determine the 
vertical extent and physical and chemical characteristics of the potential treatment zones. The hydraulic conductivity of the aquifer, which can vary by more than an order of magnitude in the glacial stratified drift on Cape Cod depending on local grain-size distributions and sorting, was estimated from the generalized stratigraphy at the well cluster and from aquifer tests conducted elsewhere on Cape Cod (Masterson and Barlow, 1997). The horizontal hydraulic gradients, obtained from water levels in shallow wells, were most representative of flow in shallow groundwater (that is, near the water table); gradients in deeper groundwater were not determined. Thus, the calculated ISI loads are based on limited data and considered to be preliminary.

Nonetheless, calculated loads agreed reasonably well with estimated WatershedMVP loads (table 7). Percent differences ranged from 9 percent at the Sailfish Drive site to 71 percent at the Herring Brook Way site. This comparison shows that, despite differences in the quantity being measured (the WatershedMVP value is based on the nitrogen input to the groundwater-contributing area to the PRB, whereas the ISI value is based on actual conditions in the aquifer), the WatershedMVP application provides reasonable first-order approximations of nitrogen loads to potential PRBs at most of the sites. On the other hand, the updated FSI load at the Vinland Drive site, which was based on a more comprehensive site characterization and assumed to be more representative of actual conditions, shows that the preliminary ISI and WatershedMVP loads should be treated with caution. The FSI-determined nitrogen load ( $550 \mathrm{~kg} / \mathrm{yr}$ nitrate as $\mathrm{N})$ was 25 percent of the ISI-determined load (2,200 kg/yr nitrate as N; "SiteAssessment Results" section of this report), with most of the difference being from the flatter hydraulic gradients and lower hydraulic conductivities that were measured during the FSI compared with the ISI. If the FSI-determined load is more representative of site conditions, this comparison indicates that limited data may not be sufficient to determine loads at relatively complex sites and that additional site characterization is important. Comparisons between ISI- and FSI-determined loads at the less complex sites would have provided additional insight into data needs for load estimation and, more generally, the phased site-assessment approach, but these comparisons were beyond the scope of this study.

The phased site-assessment approach demonstrated at the Vinland Drive site showed that flexibility is important and that the level of assessment needs to be proportional to the complexity of the site and the length of the proposed PRB. At the Vinland Drive site, substantial additional work was required after the initial investigation to fully characterize site conditions and obtain the data potentially needed for PRB design and installation. The understanding of site conditions that emerged during the FSI (for example, two distinct aquifers separated by a continuous clay layer and tidal effects on groundwater levels) required in-field adjustments to the scope of the FSI and return visits to address data gaps. Sites with less variable subsurface conditions presumably would require less characterization before PRB installation. Because this study focused on the preinstallation site-characterization process, the adequacy of the FSI for obtaining the data required for PRB design and long-term monitoring was not evaluated; however, additional data collection for performance monitoring likely would be required.

Overall the goal of the phased site-assessment approach was to strike a balance between too little and too much site characterization. Not enough site characterization data may result in installation of a poorly performing PRB because of unfavorable hydrologic or water-quality conditions. Too much site characterization data may result in unnecessary expenditures of time and resources, undermining the apparent cost and logistical advantages of PRBs compared with other nitrogen-remediation options. The site-assessment approach outlined in this report attempts to determine site suitability by a phased acquisition of data and assessment of results. In this way, sites unsuited for a PRB will be eliminated from consideration at the appropriate stage in the site investigation, whereas well-suited sites will be efficiently investigated to acquire the optimal amount of data needed to support PRB design and installation.

\section{Summary}

Wastewater disposal associated with rapid population growth and development on Cape Cod, Massachusetts, has resulted in widespread contamination of groundwater with nitrogen and impairment of many streams, lakes, and coastal embayments from excess nitrogen. To reduce nitrogen loads to these water bodies, both traditional (sewering) and alternative wastewater management options are under consideration for restoring water quality in impaired surface-water bodies. Permeable reactive barriers (PRBs), which are reactive zones emplaced below the water table for passive treatment of groundwater contaminants, are one of the alternative options being considered by Cape Cod towns as a cost-effective technology for the removal of nitrogen from groundwater. However, the effectiveness of PRBs depends on local conditions, and site-specific hydrologic and water-quality data are needed to inform the decision to install a PRB in a given location. Because these data are not available for most locations on Cape Cod, site assessments are needed before this treatment option can be considered for these locations. To address this need, the U.S. Environmental Protection Agency, U.S. Geological Survey, and Cape Cod Commission formed a technical team in 2015 to develop and evaluate a hydrologic site-assessment approach for permeable reactive barrier installation. The assessment approach was intended to provide the hydrologic data needed to make informed decisions on site suitability and to support installation and long-term monitoring should the site be deemed appropriate for a permeable reactive barrier.

The site-assessment approach evaluated in this study included a preliminary regional assessment followed by a 
phased onsite investigation. The approach was demonstrated by conducting a preliminary assessment of 27 sites nominated by Cape Cod towns, from which 5 sites were selected for onsite investigations. The factors that were considered to inform site selection and characterize local hydrologic conditions included groundwater flow directions and rates, depth to the water table, hydraulic conductivity and degree of heterogeneity of the aquifer, spatial distribution and concentration of nitrate and oxidation-reduction (redox)sensitive constituents, thickness and depth of the treatment zone, distance to downgradient water bodies, and access for drilling and permeable reactive barrier installation. The preliminary assessment provided a first approximation of conditions at the 27 nominated sites based on available regional information. To conduct the assessment, criteria such as groundwater-flow, nitrogen-loading, and site-access considerations were established to identify favorable locations for PRB installation at the watershed and local scales. Information from several data sources developed by the Cape Cod Commission (the PRB Viewer and WatershedMVP application) was used to evaluate these criteria at the nominated sites.

The five sites that were determined to be potentially favorable locations for permeable reactive barrier installation and selected for onsite investigations were the Prince Avenue near Prince Cove site in Barnstable, the Sailfish Drive near Bournes Pond site in Falmouth, the Herring Brook Way near Kescayo Gansett Pond (Lonnies Pond) site in Orleans, the Timber Landing Road near the Mashpee River site in Mashpee, and the Vinland Drive near Kelleys Bay site in Dennis. The onsite investigations were designed for proposed permeable reactive barriers of approximately 1,000 feet (ft; 305 meters [m]) in length, which was assumed to be a representative length for a full-scale permeable reactive barrier on Cape Cod. The initial site investigations consisted of a minimum of five water-table wells, one continuous core, one vertical well cluster consisting of short (1-ft; $0.3-\mathrm{m})$ screens at the core location, two rounds of hydraulic-head measurements, and two rounds of water-quality sample collection. The initial site investigations were designed to develop a preliminary conceptual model of hydrologic and water-quality conditions at the sites. A second investigation, referred to as a full site investigation, was conducted at the Vinland Drive near Kelleys Bay site in Dennis to refine the site characterization and obtain the additional hydrologic information needed to design and install a permeable reactive barrier at the site. Site investigations were conducted by WaterVision, LLC.

Study results indicated that the site-assessment approach was successful for screening sites and characterizing the geologic, hydrologic, and water-quality conditions at the sites selected for onsite investigations. The preliminary regional assessment provided important screening-level information that was used to identify potentially viable locations for permeable reactive barrier installation. However, the regional assessment alone was not sufficient to assess site viability because it provided no information on actual subsurface conditions. All five sites selected for initial site investigations were determined to be potentially viable locations based on the regional assessment, but geologic data collected during the initial site investigations showed that at least one site (Herring Brook Way near Kescayo Gansett Pond in Orleans) likely was not well suited for a permeable reactive barrier because of the presence of interlayered clay and fine-grained sediments in the PRB treatment zone. This site exemplifies why core collection is an essential component of the site-assessment process. Even if geologic information were available from previous hydrogeologic investigations, additional site-specific data would be required to verify local hydrologic and water-quality conditions and determine treatment-zone dimensions.

The data collected during the initial site investigations generally were adequate for developing a preliminary understanding of hydrologic and water-quality conditions and determining whether the sites were good candidates for PRB installation. The initial site investigations provided data on local groundwater flow directions, horizontal and vertical hydraulic gradients, depths to groundwater, and horizontal and vertical distributions of water-quality constituents. Site access was found to be an important consideration; in some locations, access limited well placement, adversely affecting water-table mapping, and underground and overhead utilities were a consideration at most of the sites.

Data were used to make preliminary estimates of the dimensions of a PRB treatment zone and the nitrogen loads in groundwater at the site. Nitrate concentrations ranged from not detected to about 7 milligrams per liter nitrate as nitrogen $(\mathrm{N})$, with median concentrations of about 2 milligrams per liter nitrate as $\mathrm{N}$ in zones where nitrate concentrations were above background levels (that is, at the potential treatment zones). These relatively low nitrate levels were sufficient to produce annual loads of hundreds to thousands of kilograms of nitrate as N. Based on the data collected at the five Cape Cod sites in this study, maximum treatment-zone depths ranged from 60 to $80 \mathrm{ft}$ (18 to $24 \mathrm{~m}$ ) below land surface. Although the initial site investigations provided the hydrologic, lithologic, and waterquality data needed to determine the suitability of candidate sites, data were not adequate to completely characterize site conditions, particularly at the sites with variable subsurface geology. A phased site-assessment approach typically will be required to fully characterize sites for permeable reactive barrier installation, and the level of assessment would need to be proportional to the complexity of the site and the length of the proposed PRB. At the Vinland Drive site where a laterally extensive clay layer was present between upper and lower sand units, substantial additional field work was required after the initial investigation to fully characterize site conditions and obtain the data needed for permeable reactive barrier installation.

By using a phased approach, sites that are not well suited for a permeable reactive barrier can be eliminated from consideration at the appropriate stage in the site investigation, whereas well-suited sites can be efficiently investigated to acquire the optimal amount of data needed 
to support permeable reactive barrier design and installation. The approach provides a template for town officials and other stakeholders to follow when considering PRBs for passive treatment of nitrogen in groundwater on Cape Cod and elsewhere.

\section{References Cited}

Borden, R.C., 2007, Effective distribution of emulsified edible oil for enhanced anaerobic bioremediation: Journal of Contaminant Hydrology, v. 94, nos. 1-2, p. 1-12. [Also available at https://doi.org/10.1016/j.jconhyd.2007.06.001.]

Cape Cod Commission, 2015, 208 plan-Cape Cod area wide water quality management plan update: Cape Cod Commission, Barnstable, Mass., June [variously paged]. [Also available at https://sp.barnstablecounty.org/ccc/public/ Documents/208\%20Final/Cape_Cod_Area_Wide_Water_ Quality_Management_Plan_Update_June_15_2015-Printable.pdf.]

Cape Cod Commission, 2017, PRB viewer: Cape Cod Commission website, accessed 2017 at http://gis-services.capecodcommission.org/apps/JS_Developing/prb/viewer.html.

Cape Cod Commission, 2018, Watershed multi variant planner: WatershedMVP website, accessed 2018 at http://www.watershedmvp.org/.

Halford, K.J., and Kuniansky, E.L., 2002, Spreadsheets for the analysis of aquifer-test and slug-test data (ver. 1.2, July 2, 2004): U.S. Geological Survey Open-File Report 02-197, 51 p., spreadsheets, accessed 2017 at https://doi.org/10.3133/ofr02197.

Interstate Technology and Regulatory Council, 2011, Permeable reactive barrier-Technology update (ver. 1.1, November 30, 2011): Interstate Technology and Regulatory Council PRB-5, 179 p., appendixes, accessed 2017 at http://www.itrcweb.org/Guidance/ListDocuments?topicID= 19\&subTopicID=23.

Jaynes, D.B., Kaspar, T.C., Moorman, T.B., and Parkin, T.B., 2008, In situ bioreactors and deep drain-pipe installation to reduce nitrate losses in artificially drained fields: Journal of Environmental Quality, v. 37, no. 2, p. 429-436. [Also available at https://doi.org/10.2134/jeq2007.0279.]

LeBlanc, D.R., Garabedian, S.P., Hess, K.M., Gelhar, L.W., Quadri, R.D., Stollenwerk, K.G., and Wood, W.W., 1991, Large-scale natural gradient tracer test in sand and gravel, Cape Cod, Massachusetts-1. Experimental design and observed tracer movement: Water Resources Research, v. 27, no. 5, p. 895-910. [Also available at https://doi.org/10.1029/91WR00241.]
Lee, M.D., Lee, J.E., and Raymond, R.L., Jr., 2013, EVO carbon footprint, distribution, and longevity - Summary of SRS case histories, E-21 of Sirabian, R.R., and Darlington, R., chairs, Bioremediation and sustainable environmental technologies - 2013: International Symposium on Bioremediation and Sustainable Environmental Technologies, 2d, Jacksonville, Florida, June 10-13, 2013, proceedings, [n.p.]. [Also available at https://projects.battelle.org/bioremediation-symposium/2013Bio_Proceedings_Download.zip.]

Long, L.M., Schipper, L.A., and Bruesewitz, D.A., 2011, Long-term nitrate removal in a denitrification wall: Agriculture, Ecosystems, and Environment, v. 140, nos. 3-4, p. 514-520. [Also available at https://doi.org/10.1016/j.agee.2011.02.005.]

Massachusetts Estuaries Project, 2018, The Massachusetts Estuaries Project and Reports: Massachusetts Estuaries Project website, accessed February 2018 at http://www.oceanscience.net/estuaries/. [Website has been reorganized and information is available at https://www.mass.gov/guides/the-massachusetts-estuariesproject-and-reports as of March 19, 2019.]

MassGIS, 2018, MassGIS (Bureau of Geographic Information): MassGIS website, accessed June 3, 2018, at https://www.mass.gov/orgs/massgis-bureau-of-geographicinformation.

Masterson, J.P., and Barlow, P.M., 1997, Effects of simulated ground-water pumping and recharge on ground-water flow in Cape Cod, Martha's Vineyard, and Nantucket Island basins, Massachusetts: U.S. Geological Survey Water-Supply Paper 2447, 79 p. [Also available at https://doi.org/10.3133/wsp2447.]

Robertson, W.D., 2010, Nitrate removal rates in woodchip media of varying age: Ecological Engineering, v. 36, no. 11, p. 1581-1587. [Also available at https://doi.org/10.1016/j.ecoleng.2010.01.008.]

Robertson, W.D., and Cherry, J.A., 1995, In situ denitrification of septic-system nitrate using reactive porous media barriers-Field trials: Ground Water, v. 33, no. 1, p. 99-111. [Also available at https://doi.org/10.1111/j.1745-6584.1995. tb00266.x.]

Schipper, L.A., and Vojvodic-Vukovic, M., 1998, Nitrate removal from groundwater using a denitrification wall amended with sawdust-Field trial: Journal of Environmental Quality, v. 27, no. 3, p. 664-668. [Also available at https://doi.org/10.2134/jeq1998.00472425002700030025x.] 
Truslow, D., Large, S., Boudreau, A., Shanahan, P., DiFranco, E., and Hickey, K., 2017, Characterization for design of pilot-scale permeable reactive barriers for nitrogen reduction in groundwater on Cape Cod, MA: U.S. Environmental Protection Agency WaterVision, LLC, final hydrogeologic assessment report, under contract \# EP-BPA-13-W-0001, 64 p. [Also available at https://www.epa.gov/sites/ production/files/2018-10/documents/hydrogeologic-assessment-report-vinland-drive.pdf.]

Truslow, D., and Shanahan, P., 2017, Site characterization for design of pilot-scale permeable reactive barriers for nitrogen reduction in groundwater on Cape Cod-Supplemental fieldwork at Prince Cove, Barnstable, Massachusetts: U.S. Environmental Protection Agency WaterVision, LLC, technical memorandum, under contract \# EP-BPA13-W-0001, [variously paged]. [Also available at https://www.epa.gov/sites/production/files/2018-10/ documents/tech-memo-cape-prb-barnstable-suppl-waterquality-sampling.pdf.]
Truslow, D., Wright, S., Shanahan, P., DiFranco, E., and Hickey, K., 2016, Cape Cod permeable reactive barrierInitial hydrogeologic site characterization results and evaluation of site suitability for permeable reactive barrier installation: U.S. Environmental Protection Agency WaterVision, LLC, report, under contract \# EP-BPA-13-W-0001, [variously paged]. [Also available at https://www.epa.gov/ snecwrp/cape-cod-permeable-reactive-barrier-prb-pilotproject.]

Walter, D.A., and Whealan, A.T., 2005, Simulated water sources and effects of pumping to wells and surface waters, Sagamore and Monomoy flow lenses, Cape Cod, Massachusetts: U.S. Geological Survey Scientific Investigations Report 2004-5181, 85 p. [Also available at https://doi.org/10.3133/sir20045181.] 

For more information about this report, contact: Director, New England Water Science Center U.S. Geological Survey 331 Commerce Road, Suite 2

Pembroke, NH 03275-3718

dc_nweng@usgs.gov or visit our website at https://newengland.water.usgs.gov

Publishing support provided by the Pembroke Publishing Service Center 

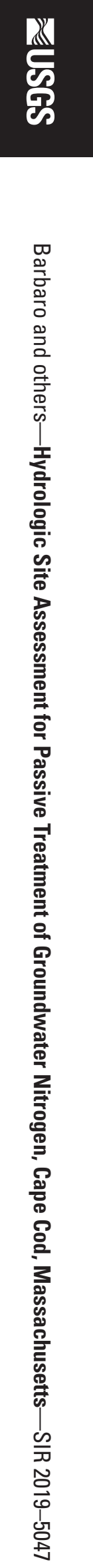